\title{
Development of Value-added Food Products from Isoelectrically Recovered Proteins
}

\author{
Reza Tahergorabi \\ West Virginia University
}

Follow this and additional works at: https://researchrepository.wvu.edu/etd

\section{Recommended Citation}

Tahergorabi, Reza, "Development of Value-added Food Products from Isoelectrically Recovered Proteins" (2012). Graduate Theses, Dissertations, and Problem Reports. 3592.

https://researchrepository.wvu.edu/etd/3592

This Dissertation is protected by copyright and/or related rights. It has been brought to you by the The Research Repository @ WVU with permission from the rights-holder(s). You are free to use this Dissertation in any way that is permitted by the copyright and related rights legislation that applies to your use. For other uses you must obtain permission from the rights-holder(s) directly, unless additional rights are indicated by a Creative Commons license in the record and/ or on the work itself. This Dissertation has been accepted for inclusion in WVU Graduate Theses, Dissertations, and Problem Reports collection by an authorized administrator of The Research Repository @ WVU.

For more information, please contact researchrepository@mail.wvu.edu. 


\title{
Development of Value-added Food Products from Isoelectrically Recovered Proteins
}

\author{
Reza Tahergorabi \\ Dissertation submitted to the \\ Davis College of Agriculture, Natural Resources and Design \\ at West Virginia University \\ in partial fulfillment of the requirements \\ for the degree of \\ Doctor of Philosophy \\ in \\ Animal and Food Science \\ Jacek Jaczynski, Ph.D., Chair \\ Gary K. Bissonnette, Ph.D. \\ P. Brett Kenney, Ph.D. \\ Kristen E. Matak, Ph.D. \\ Janet C. Tou, Ph.D.
}

Division of Animal and Nutritional Sciences

Morgantown, West Virginia

2012

Keywords: Isoelectric Solubilization/Precipitation; Proteins; Functional Ingredients;

Food Product Development

Copyright 2012 Reza Tahergorabi 


\section{ABSTRACT}

\section{Development of Value-added Food Products from Isoelectrically Recovered Proteins}

\section{Reza Tahergorabi}

The amount of fish by-products is huge and there is a large potential for making more value-added products from this raw material. On the other hand, dark chicken meat has been considered as a major underutilized commodity due to the increasing demand for further processed breast meat products. If proper meat recovery technology is successfully applied, the recovered meat can result in added revenue for a processor as well as reduce environmental pollution associated with disposal of the processing by-products. The overall objective of this study was to recover functional proteins from whole gutted fish and dark chicken meat by using isoelectric solubilization/precipitation (ISP). Product development that incorporates the "voice of consumer" is crucial to understand and satisfy consumers' needs to manage these product development challenges.

Color properties of restructured products made of proteins recovered from chicken processing by-products is poor. The by-products contain bones, skin, fat, etc. that affect color of restructured products. Therefore, in the first study, effect of $\mathrm{TiO}_{2}$ as a whitening agent at 0-1 $\mathrm{g} / 100 \mathrm{~g}$ and canola oil at $10 \mathrm{~g} / 100 \mathrm{~g}$ on color and texture of heat-set gels were investigated. $\mathrm{TiO}_{2}$ at $1 \mathrm{~g} / 100 \mathrm{~g}$ with canola oil resulted in slightly better $(\mathrm{P}<0.05)$ whiteness of drumstick gels than breast gels. $\mathrm{TiO}_{2}$ did not deteriorate gel texture, which was generally comparable to breast gels. This research indicates that ISP allows recovery of proteins from skin-on bone-in dark chickenmeat processing by-products without removal of bones, skin, and fat prior to processing. Addition of $\mathrm{TiO}_{2}$ to proteins recovered from these by-products allows development of heat-set gels with color and texture comparable to chicken breast gels.

Apart from the appearance, muscle food products can be modified by adding ingredients considered beneficial for health or by eliminating or reducing components that are considered harmful. High salt intake contributes to hypertention, the major risk factor for cardiovascular disease. Salt is commonly added during processing of seafood products to enhance protein gelation and hence texture as well as microbial safety. In the second study, salt or KCl-based salt substitute at 0 (control), $0.17,0.34$, and $0.51 \mathrm{M}$ was added to surim. This study demonstrated that salt substitute and salt result in comparable $(\mathrm{P}>0.05)$ physicochemical properties of surimi gels, but gels developed with salt substitute have significantly lower $(\mathrm{P}<0.05)$ sodium content. Therefore, salt substitute can be used to replace $\mathrm{NaCl}$ in low-sodium surimi seafood products.

The next study compared protein endothermic transitions (thermal denaturation), rheological properties (protein gelation), and fundamental texture properties (shear stress and strain at mechanical fracture) of Alaska pollock surimi gels made with 0 (control), 1, 2, and 3 $\mathrm{g} / 100 \mathrm{~g}$ of salt $(\mathrm{NaCl})$ with equal molar concentration of salt substitute. The elastic modulus $\left(\mathrm{G}^{\prime}\right)$ increased when salt or salt substitute was added to surimi. Surimi gels with salt substitute and salt at equal molar concentrations had similar texture properties (shear stress and strain). Based 
on this study, salt substitute can be used in the development of low-sodium surimi seafood products without significant change in gelation and texture.

There is an increasing interest in incorporation of $\omega$-3 PUFA rich oils in food products with a simultaneous sodium reduction. Since the protein isolate is recovered from fish and used in a formulated food product, it is a logical vehicle for increasing the consumption of $\omega$-3 PUFAs and concurrent reduction of dietary sodium. In the next study, the protein isolate was recovered from whole gutted trout (bone-in, skin- and scale-on) using ISP processing. The isolate was used as a main ingredient to develop heat-set gels made with $\omega-3$ PUFA rich oils (flaxseed, algae, fish, krill, and blend) and KCl-based salt substitute. The effect of $\omega$-3 PUFA rich oils on chemical characterization of fatty acid composition and their oxidation, spoilage index (total volatile basic nitrogen) and fundamental texture properties of trout heat-set gels was investigated. This study indicated that trout gels enriched with PUFA rich oils can be considered healthful food in terms of the risk of cardiovascular diseases.

These studies demonstrated it is feasible to develop functional food made of muscle proteins recovered with isoelectric solubilization/precipitation from low-value dark chicken meat and fish processing by-products. The functional foods developed in these studies were nutritionally enhanced and had comparable instrumental quality attributes to respective products made of chicken breast meat or surimi seafood. Although the results of these studies point towards the potential for a novel, marketable functional food product, sensory tests and storage stability study are recommended. 


\section{ACKNOWLEDGEMENTS}

First and foremost I would like to thank God. You have given me the power to believe in my passion and pursue my dreams. I could never have done this without the faith I have in you, the Almighty. To be able to step strong and smooth in this way, I have also been supported and supervised by many people to whom I would like to express my deepest gratitude.

I would like to gratefully and sincerely thank my advisor, Dr. Jacek Jaczynski, for his guidance, understanding, patience, and most importantly, his friendship during my graduate career at West Virginia University. Above all and the most needed, he provided me unflinching encouragement and support in various ways. His truly scientist intuition has made him as a constant oasis of ideas and passions in science, which exceptionally inspire and enrich my growth as a student, a researcher and a scientist want to be. I am indebted to him more than he knows.

It is a pleasure to convey my gratitude to my committee members, Dr. P. Brett Kenney, Dr. Janet Tou, Dr. Kristen Matak and Dr. Gary Bissonnette for their guidance and assistance in contributing to my research.

I specially want to thank Sarah Beamer who as a good friend was always willing to help in the lab and give her best suggestions. My research would not have been possible without her help.

I would like to thank my labmates Adiam Tesfai, Britnney Pietrowski, and Ilgin Paker for their support and Dr. Mathew Davenport who helped me to learn some techniques.

The financial support of Division of Animal and Nutritional Sciences at West Virginia University is gratefully acknowledged.

I wish to express my gratitude to my best friend, Dr. Seyed Vali Hosseini for all his helps, supports and encouragements.

Lastly, and most importantly, I am grateful to my beloved family for their encouragement and patience throughout my studies. I dedicate this work to them. 


\section{TABLE OF CONTENTS}

$\begin{array}{ll}\text { ABSTRACT } & \text { ii }\end{array}$

ACKNOWLEDGEMENTS iv

TABLE OF CONTENTS $\quad$ V

LIST OF TABLES viii

LIST OF FIGURES ix

\section{LITERATURE REVIEW}

1. Protein and Its Importance in Human Nutrition 1

2. Structure and Protein Composition of Muscle 2

3. Seafood and Poultry By-products as Nutritious Protein Sources 6

4. Alternatives for Recovery of Protein from "By-products" and "Low 7

Value" Meat

5. Functional Properties of Muscle Proteins and their Link to

Isoelectric Solubilization / Precipitation and Traditional Surimi

Production

6. Development of Functional Foods from Isoelectrically Recovered

Proteins of Seafood and Poultry By-Products

7. Physicochemical Evaluations of the Developed Food Products

References

\section{CHAPTER 1}

Effect of isoelectric solubilization/precipitation and titanium dioxide on whitening and texture of proteins recovered from dark chickenmeat processing by-products 
$\begin{array}{ll}\text { Abstract } & 47\end{array}$

$\begin{array}{ll}\text { Introduction } & 48\end{array}$

Materials and methods $\quad 51$

$\begin{array}{ll}\text { Results and discussion } & 57\end{array}$

$\begin{array}{ll}\text { Conclusions } & 63\end{array}$

$\begin{array}{ll}\text { References } & 65\end{array}$

CHAPTER 2

Salt substitution in surimi seafood and its effects on instrumental quality attributes

$\begin{array}{lr}\text { Abstract } & 79 \\ \text { Introduction } & 80 \\ \text { Materials and methods } & 81 \\ \text { Results and discussion } & 87 \\ \text { Conclusions } & 91 \\ \text { References } & 92\end{array}$

\section{CHAPTER 3}

Physicochemical changes in surimi with salt substitute
Abstract
105
$\begin{array}{ll}\text { Introduction } & 106\end{array}$
$\begin{array}{ll}\text { Materials and methods } & 108\end{array}$
$\begin{array}{ll}\text { Results and discussion } & 113\end{array}$
$\begin{array}{ll}\text { Conclusions } & 117\end{array}$
$\begin{array}{ll}\text { References } & 118\end{array}$ 


\section{CHAPTER 4}

Development of functional fish product from isoelectrically recovered proteins with $\omega-3$ rich oils and salt substitute

$\begin{array}{ll}\text { Abstract } & 128\end{array}$

$\begin{array}{ll}\text { Introduction } & 129\end{array}$

$\begin{array}{ll}\text { Materials and methods } & 131\end{array}$

Results and discussion 139

$\begin{array}{ll}\text { Conclusions } & 145\end{array}$

$\begin{array}{ll}\text { References } & 147\end{array}$

$\begin{array}{ll}\text { Dissertation summary and implications } & 160\end{array}$ 


\section{LIST OF TABLES}

CHAPTER 1

$\begin{array}{ll}\text { TABLE } 1 . & 70\end{array}$

$\begin{array}{ll}\text { TABLE 2. } & 71\end{array}$

TABLE 3.

$\begin{array}{ll}\text { TABLE } 4 . & 73\end{array}$

CHAPTER 2

TABLE $1 . \quad 96$

$\begin{array}{ll}\text { TABLE 2. } & 97\end{array}$

$\begin{array}{lr}\text { TABLE } 3 . & 98\end{array}$

$\begin{array}{lr}\text { TABLE } 4 . & 99\end{array}$

CHAPTER 3

TABLE $1 . \quad 122$

$\begin{array}{ll}\text { TABLE } 2 . & 123\end{array}$

CHAPTER 4

$\begin{array}{lr}\text { TABLE } 1 . & 156\end{array}$ 


\section{LIST OF FIGURES}

\section{LITERATURE REVIEW}

FIGURE 1. $\quad 42$

$\begin{array}{ll}\text { FIGURE } 2 . & 43\end{array}$

FIGURE 3.

CHAPTER 1

$\begin{array}{ll}\text { FIGURE 1. } & 74\end{array}$

$\begin{array}{ll}\text { FIGURE 2. } & 75\end{array}$

$\begin{array}{ll}\text { FIGURE 3. } & 76\end{array}$

$\begin{array}{ll}\text { FIGURE } 4 . & 77\end{array}$

CHAPTER 2

$\begin{array}{ll}\text { FIGURE } 1 . & 100\end{array}$

$\begin{array}{ll}\text { FIGURE 2. } & 101\end{array}$

$\begin{array}{lr}\text { FIGURE 3. } & 102\end{array}$

$\begin{array}{ll}\text { FIGURE } 4 . & 103\end{array}$

CHAPTER 3

$\begin{array}{ll}\text { FIGURE } 1 . & 124\end{array}$

$\begin{array}{ll}\text { FIGURE 2. } & 125\end{array}$

$\begin{array}{ll}\text { FIGURE } 3 . & 126\end{array}$

CHAPTER 4

$\begin{array}{ll}\text { FIGURE } 1 . & 154\end{array}$

$\begin{array}{ll}\text { FIGURE } 2 . & 155\end{array}$ 
$\begin{array}{lr}\text { FIGURE 3. } & 157\end{array}$

$\begin{array}{lr}\text { FIGURE } 4 . & 158\end{array}$

$\begin{array}{lr}\text { FIGURE 5. } & 159\end{array}$ 


\section{LITERATURE REVIEW}

\section{Protein and Its Importance in Human Nutrition}

Proteins are highly complex biochemical compounds. There are 20 different amino acids which are building blocks of all proteins. The constituents are linked via substituted amide bonds. Whilst it is clear that proteins have a major function in many biological processes, they also have a key role as food additives and ingredients. To highlight their biological importance, these macromolecules were named proteins, derived from the Greek word proteois, which means of the first kind (Damodaran, 2008).

At the elemental level, proteins contain 50-55\% carbon, 6-7\% hydrogen, 20-23\% oxygen, $12-19 \%$ nitrogen, and $0.2-3.0 \%$ sulfur. All biologically produced proteins can be used as food proteins. However, for practical purposes, food proteins may be defined as those that are easily digestible, nontoxic, nutritionally adequate, functionally useable in food products, and available in abundance. Traditionally, milk, meats (including fish and poultry), eggs, cereals, legumes, and oilseeds have been the major sources of food proteins.

Proteins differ in their nutritive value. Several factors, such as content of essential amino acids and digestibility, contribute to these differences. The daily protein requirement therefore depends on the type and composition of proteins in a diet. Adults or children consuming only cereal proteins or legume proteins have difficulty maintaining their health. The protein content of muscle tissue is high and the quality of this protein is high, containing kinds and ratios of amino acids that are similar to those required for maintenance and growth of human tissue. Of the total nitrogen content of muscle, approximately $95 \%$ is protein and 
$5 \%$ is smaller peptides, amino acids, and other compounds (Strasburg, Xiong, \& Chiang. 2008).

Digestibility of protein is defined as the proportion of food nitrogen that is absorbed after ingestion. Although the content of essential amino acids is the primary indicator of protein quality, true quality also depends on the extent to which these amino acids are utilized in the body. Thus, digestibility of amino acids can affect the quality of proteins. Food proteins of animal origin are more completely digested than those of plant origin. Several factors affect digestibility of proteins.

Since meat quality is affected by the muscle structure in the living animal, it is important to review chemical and physical composition of muscle proteins, which is discussed in the following sections.

\section{Structure and Protein Composition of Muscle}

\subsection{Skeletal Muscle}

A schematic diagram of the muscle structure in birds and mammals is shown in Figure 1. The fibers are arranged in parallel fashion to form bundles, and groups of bundles form a muscle. Surrounding the whole muscle is a heavy sheath of connective tissues, called the epimysium. From the inner surface of the epimysium, other connective tissues penetrate the interior of the muscle, separating the groups of fibers into bundles. This connective tissue layer surrounding groups of fibers is termed the perimysium, and extending from this are finer sheaths of connective tissue that surround each muscle fiber. These last sheaths are termed endomysium. The connective tissue sheaths merge with large masses of connective tissue tendons at the termini of the muscle, with these merger points serving to anchor the 
muscle to the skeleton. The long components of the circulatory system are located in the perimysium, whereas the smaller units (capillaries) are within the endomysium.

The arrangement of muscle fibers in fish is quite different from that in birds and mammals and is based on the need to flex their bodies for propulsion through water. The arrangement of the muscle tissue in a typical bony fish is shown in Figure 2. The "W" shaped segments are called myotomes, and they have one forward and two backward flexures. The myotomes are one cell deep, and the muscle cells are roughly perpendicular to the surface of the myotome. The myotomes are connected one to another by thin layers of collagenous connective tissue called myosepta (myocommata) (Tahergorabi, Hosseini, \& Jaczynski, 2011).

Muscle fibers are the units which form a muscle bundle. Each muscle fiber consists of myofibrils and each myofibril contains myofilaments. The sarcomere is a small muscle unit which is involved in muscle contraction (Figure 2). There is a dark area in which a thick filament (myosin) and a thin filament (actin) overlap. This area is known as the A-band. There is a light area in the A-band which contains no thin filaments called the H-zone. The Z-line is the area which determines the borders of a sarcomere, and it is composed of narrow dark bands of proteins (Strasburg, Xiong, \& Chiang, 2008). Muscle contraction occurs when thick filaments slide toward the Z-line (Barbut, 2002).

\subsection{Muscle Proteins}

Muscle proteins can be divided into three major groups according to their water solubility characteristics, myofibrillar proteins, sarcoplasmic proteins, and stroma proteins (Connell, 1980). Myofibrillar proteins are the proteins that form myofibrils. They are soluble in concentrated saline solutions (ionic strength above 0.6) as well as extremely low ionic 
strength. Myofibrillar proteins are composed of myosin, actin, and regulatory proteins such as tropomyosin, troponin and actinin (Figure 2). Myofibrillar proteins are 66-77\% of total proteins in muscle and provide several functional properties that are useful in food products. Generally, seafood myofibrillar proteins are less thermally stable than the proteins isolated from terrestrial animals. The $\mathrm{pH}$ and ionic strength affect thermal stability of seafood myofibrillar proteins, and hence, heat-induced denaturation. Myofibrillar proteins isolated from cold water species are typically less thermally stable than warm water species. Protein gelation and rheological properties responsible for texture development, and therefore, consumer acceptability primarily depend on the quality of myofibrillar proteins, which is affected by seafood species, age, seasonality, freshness, and processing parameters such as protein concentration, $\mathrm{pH}$, ionic strength and temperature (Suzuki, 1981).

Actin constitutes about $20 \%$ of the total amount of myofibrillar proteins in muscle. Actin is easily extracted. However, this characteristic presents a problem when pure myosin is to be isolated, because the extracted actin spontaneously forms actomyosin complex in the solution and hinders isolation of pure myosin. Therefore, actomyosin is the main form of salt-soluble muscle proteins. Tropomyosin and troponin regulate muscle contraction. Tropomyosin is the most heat stable muscle protein and is easily purified. Troponin is a necessary protein for tropomyosin to act as a relaxation factor during muscle contraction. Water solubility of myofibrillar protein varies depending on the temperature, $\mathrm{pH}$, and ionic strenght. Extreme $\mathrm{pH}$ and high temperature cause protein denaturation resulting in low solubility (Tahergorabi et al., 2011).

Sarcoplasmic proteins contain several individual types of water-soluble proteins called myogen. Since sarcoplasmic proteins are completely water-soluble, they are isolated from 
muscle by simply pressing the muscle tissue or by extraction with low ionic strength saline solution. Sarcoplasmic proteins may enhance thermal gelation of myofibrillar proteins. There are probably several factors that govern heat-induced gelation of myofibrillar proteins in the presence of sarcoplasmic proteins. Sarcoplasmic proteins are comprise of myoglobin, hemoglobin, globins, albumins, and some enzymes which are more water-soluble than other types of muscle proteins (Connell, 1980).

Stroma proteins form connective tissue in the muscle structure. These proteins are completely water insoluble. They cannot be extracted in acid or alkaline solution, or physiological saline solution. The components of stroma proteins are collagen and elastin. Elastin is very resistant to moist heat and cooking does not affect elastin in the connective tissue.

\subsection{Muscle Fiber Type}

According to this approach, all muscles are classified as either fast-twitch or slow-twitch. Fast-twitch (white or light in appearance) muscles have a more rapid progression to peak tension and decline to resting tension than do slow-twitch (red or dark appearance) muscles. Fast-twitch muscles are found in anatomical locations where forceful movement is needed; whereas, slow-twitch muscles are associated with long sustained contraction, that is, for maintenance of posture. Their appearance, red versus white, is related to their energy metabolism. Fast-twitch muscles require a rapid source of energy, so glycolysis is the predominant pathway used by these muscles. Slow-twitch muscles rely primarily on oxidative metabolism. This metabolism requires a large amount of myoglobin for oxygen storage, and these muscles are therefore redder (or darker) than fast-twitch (white) muscles. 
The differences between white (fast-twitch) breast muscles of poultry and red (slow-twitch) thigh muscles are easy to distinguish based on appearance (Barbut, 2002).

In fish muscle, fiber types are more distinctive than in mammalian or avian muscles. The dark muscle is concentrated superficially, particularly near the lateral line - a group of skin sensory organs extending in a single row, from head to tail, along the surface of each side of the body. In a few fish, such as tuna, which are very active and fast swimmers, deep-seated dark muscle is also present. In some species of fish, particularly salmonids, a few isolated dark fibers are scattered throughout the main bulk of the white muscle.

\section{Seafood and Poultry By-products as Nutritious Protein Sources}

Definition of food processing "by-products" has been misunderstood. Three terms namely "offal", "waste", and "by-products" are frequently and interchangeably used in the fish and poultry processing industry and scientific literature to describe the same materials (Gehring, Gigliotti, Moritz, Tou, \& Jaczynski, 2010). The first two terms imply that those materials cannot be used for any application and should be disposed of; and therefore, are often misleading and trigger a negative connotation. While the third term suggests that there may be some valuable components to be recovered if treated properly; and therefore, it is a positive term. Currently, the most common definition of "by-products" is all of the edible or inedible materials left over following processing of the main product. A typical example is fish filleting to recover boneless and skinless marketable fillets. The fillets would be considered the main product and the frames, heads, and viscera would be typical "byproducts" (Strom, \& Eggum, 1981).

There are different estimates as to how much by-products are available. FAO estimates postharvest losses to be $25 \%$ of the catch. The amount of by-products in fish varies 
depending on species, size, season and fishing ground (Falch et al., 2006); however, up to $50 \%$ of the fish is commonly discarded when preparing seafood industrially (Guerard, Sellos, \& Gal, 2005). Others claim that seafood processing discards and by-products make up around $75 \%$ of the total weight of the catch (Shahidi, 1994). With a grand total of more than 90 million metric tons (FAO, 2011), the amount of marine by-products is huge and there is a large potential for making more value-added products from this raw material.

In the United States, white chicken meat is preferred over dark meat (USDA, 2000). Therefore, with the increasing demand for further processed breast meat products (i.e. white meat), dark chicken meat has been regarded as a by-product (USDA, 2004). The major concerns with dark chicken meat that affect consumers' selection and satisfaction are color (due to heme pigments containing iron), high fat content and poor shelf stability (Froning 1995; Fletcher, 1997; Betti \& Fletcher, 2005). Low value dark poultry meat should not be considered only as muscle tissue which is processed into traditional forms of food, but rather as a source of functional ingredients for food product development. If proper meat recovery technology is successfully applied, the recovered meat can result in added revenue for a processor as well as reduce environmental pollution associated with disposal of the processing byproducts.

\section{Alternatives for Recovery of Protein from "By-products" and "Low Value" Meat}

Among previous efforts to improve the utilization of these kinds of raw materials are inventions involving different types of deboning equipment. Several suitable mechanical methods of separation are known. Most well-known are the deboning machines from Baader and Bibun in which the flesh is pressed through perforations in a rotating drum, by means of a powerful rubber belt, leaving bone, etc. behind. In fish processing, the deboners are mainly 
used in production of mince from beheaded and eviscerated fish, from whole fillets or from off-cuts from the trimming of fillets. However, it can also be used for separating the meat left on the backbones, collarbones and heads, etc. To obtain a good yield from such low cost raw materials, it is necessary to use a high belt pressure which implies drawbacks like decolorization by blood and other pigments as well as other unwanted substances like skin, small bones, cartilage, etc. The most important options to increase the utilization of "low value" dark meat include traditional surimi technology and isoelectric solubilization/ precipitation. These technologies aim to concentrate and isolate muscle proteins from this type of raw materials (Nolsoe, \& Undeland, 2009).

\subsection{Conventional (Traditional) Surimi Processing Technology}

Surimi is a Japanese term for deboned, minced, and washed fish flesh, which is then used for the manufacture of seafood imitation products such as crab legs. These are perceived to have wholesome and nutritious attributes (Guenneugues \& Morrissey, 2005), which, together with an affordable price, have contributed to the increasing worldwide consumption of surimi-based products. However, given that the demand for fish is increasing, it is clear that its availability is decreasing, particularly for some fisheries. The commercial demand for the white-fleshed fish is higher than for others and therefore, the industry mainly depends on them (Venugopal, 1997; Venugopal \& Shahidi, 1998). The surimi industry also demands white fish mainly because of the importance of the whiteness and textural properties of the resulting products (Park, 2005). Thus, to remove unwanted compounds abundant in minces, e.g., from dark muscle fish, efforts have been carried out to produce surimi. The traditional surimi process involves three washes with three volumes of water or a slightly alkaline solution. In the washes, water-soluble compounds are diluted and some of the neutral fat is 
removed, and cryprotectants are added before freezing in blocks. Unfortunately, storage stability can remain a problem also after washing most likely because of severe dilution of the natural antioxidants in the fish raw material (Undeland, Ekstrand, \& Lingnert, 1998). Also, the loss of sarcoplasmic proteins and some of the myofibrillar proteins into the wash water reduces the total protein yield of the surimi process. However some efforts have been made to avoid this. Niki, Kato, Deya, \& Igarashi (1985), for example, adjusted the pH of the first wash water effluent to 10 . Insoluble "black" proteins were then removed from the effluent by centrifugation. The $\mathrm{pH}$ of the effluent was then adjusted to $\sim \mathrm{pH} 5$; thereafter the effluent was heated at $80{ }^{\circ} \mathrm{C}$. This treatment allowed the coagulated protein to be separated from the effluent. The yield of the recovered proteins was about $20 \%$ of the surimi products. Surimi processing is commercially used for headed-and-gutted fish (i.e., clean muscle tissue). Among other limitations, surimi processing cannot be applied to food processing by-products and offers relatively low recovery yields when compared to isoelectric solubilization/precipitation (ISP) (Gehring et al., 2010). This is why surimi technology cannot be directly applied to dark chicken-meat and fish processing by-products unless meat is first recovered by mechanical deboning. Proteins recovered from mechanically deboned chicken-meat and fish by-products using surimi technology often have unacceptable color and the heat-set gels made from these proteins have poor texture (i.e., gelation), color properties, and an undesirable odor (Stangierski \& Kijowski, 2000). In contrast, proteins recovered from food processing by-products containing bones, skin, etc. with ISP have been shown to retain gel-forming ability; and therefore, gels made from these proteins have good texture and also color properties (Taskaya, Chen, \& Jaczynski, 2010). 


\subsection{Isoelectric Solubilization/Precipitation: A New Technology for the Recovery of Functional Proteins}

The isoelectric solubilization/precipitation (ISP) of muscle proteins with concurrent separation of lipids was proposed by food scientists from University of Massachusetts (Hultin \& Kelleher, 1999; 2000; 2001; 2002). Following these pioneering developments along with earlier work by Meinke, Rahman, \& Mattil (1972) as well as Meinke and Mattil (1973), several food science laboratories began active research in the ISP field.

In fish muscle homogenates, myofibrillar proteins are present as aggregates that are held together by weak protein-protein hydrophobic interactions (Undeland, Kelleher, Hultin, McClements, \& Thongraung, 2003). However, depending on the conditions that the fish muscle proteins are subjected to, the protein side chains can assume different electrostatic charges (Figure 3). This means that the solubility of fish muscle proteins can be "turned" on or off by providing conditions that either favor or disfavor protein solubility, respectively. When acid is added to a solution, it dissociates yielding hydronium ions $\left(\mathrm{H}_{3} \mathrm{O}^{+}\right)$. Protonation of negatively charged side chains on glutamyl or aspartyl residues results in an increased net positive surface charge. Similarly, when base $\left(\mathrm{OH}^{-}\right)$is added to a solution, deprotonation of side chains on tyrosyl, tryptophanyl, cysteinyl, lysyl, argininyl or histidinyl residues contributes to an increased net negative surface charge (Figure 3). Consequently, solubilization of fish muscle proteins is ascribed to protonation of aspartyl and glutamyl ( $\mathrm{p} K_{\mathrm{a}}=3.8$ and 4.2 , respectively) residues at acidic $\mathrm{pH}$ and deprotonation of lysyl, tyrosyl and cysteinyl ( $\mathrm{p} K_{\mathrm{a}}=9.5-10.5,9.1-10.8$, and 9.1-10.8, respectively) residues at basic $\mathrm{pH}$. When the charge equilibrium is reached and a protein solution attains homeostasis, the final status of a protein surface electrostatic charge at a given $\mathrm{pH}$ is referred to as the net charge. The 
accumulation of a net positive or negative charge induces protein-protein electrostatic repulsion and an increased hydrodynamic volume due to expansion and swelling (Undeland, Kelleher, Hultin, McClements, \& Thongraung, 2003; Kristinsson, Theodore, Demir, \& Ingadottir, 2005).

As proteins assume more positive or negative net charge, they gradually start electrostatic interactions with water (i.e., protein-water interactions). Due to increased protein-water interactions, the protein-protein hydrophobic interactions decrease. Therefore, as the protein molecules become more polar (charged), more water associates on and around the protein surface and proteins become water-soluble. However, it is possible to adjust the $\mathrm{pH}$ of a protein solution so that the number of negative charges on a protein's surface is equal to the number of positive charges; and therefore, the protein molecule assumes a zero net electrostatic charge. The $\mathrm{pH}$ at which the net electrostatic charge of a protein is equal to zero is called the isoelectric point (pI) (Figure 3). The pI is very specific for different proteins, and isoelectric focusing is often used to pinpoint the pI.

The $\mathrm{pI}$ of fish muscle proteins is an important parameter because as the charges on a protein's surface diminish, so do the protein-water interactions; and hence, protein water solubility and water-holding-capacity (WHC). In addition, proteins gel poorly at their pI. However, the hydrophobicity driven protein-protein interactions are favored at the pI; and therefore, proteins at their $\mathrm{pI}$ achieve minimum solubility and typically precipitate. This $\mathrm{pH}-$ mediated, protein isoelectric behavior allows modification of protein solubility/precipitation by proper $\mathrm{pH}$ adjustment. Ionic strength (IS) influences $\mathrm{pH}$-mediated ISP (Thawornchinsombut \& Park, 2004; Chen \& Jaczynski, 2007). 
The second major group of fish muscle proteins, sarcoplasmic proteins, is water-soluble at acidic and basic $\mathrm{pH}$. However, sarcoplasmic proteins do not precipitate as demonstrably between $\mathrm{pH}$ 5.0-6.0 as myofibrillar proteins. As the IS increases, more sarcoplasmic proteins precipitate at pH 5.5 (Chen \& Jaczynski, 2007b). Therefore, in a continuous system, more sarcoplamic proteins are recovered as salt accumulation increases.

The isoelectric behavior of muscle proteins can be used to recover functional proteins from aquatic animals processing by-products as well as low-value poultry meat. While muscle proteins are in a soluble form (protein-water interactions are favored), the insoluble components (bone, skin, scale, etc.) can be removed from the solution by for example centrifugation, followed by protein precipitation and recovery at the $\mathrm{pI}$ (protein-protein interactions are favored). Functional muscle proteins from fish have thus far been recovered at the laboratory scale using a batch mode (Undeland, Kelleher, \& Hultin, 2002; Choi \& Park, 2002; Kristinsson \& Hultin, 2003; Kim, Park, \& Choi, 2003) and pilot plant scale (Mireles DeWitt, Nabors, \& Kleinholz, 2007). The ISP processing with continuous centrifugation has also been applied to fish processing by-products (Chen \& Jaczynski, 2007), krill (Chen \& Jaczynski, 2007; Chen et al., 2009), and whole fish (Taskaya, Chen, \& Jaczynski, 2009a; Taskaya, Chen, Beamer, \& Jaczynski, 2009b). Additionally, ISP has been used to recover proteins and lipids from beef processing by-products (Mireles DeWitt, Gomez, \& James, 2002), mechanically deboned turkey (Liang \& Hultin, 2003), and chicken (Kelleher \& Hultin, 2000).

Many published works have suggested that ISP processing of fish at basic $\mathrm{pH}$ allows recovery of proteins with generally better functionalities than acidic; and therefore, better thermally-induced gelation and consequently texture as well as better color (i.e., whiteness) 
properties (Chen \& Jaczynski, 2007a; 2007b; Nolsoe \& Undeland, 2009; Taskaya et al., 2009a; 2009b). In addition, ISP at basic $\mathrm{pH}$ allows recovery of muscle proteins with higher nutritional quality as assessed by a greater content of essential amino acids (EAAs) when compared to ISP at acidic pH (Chen et al., 2007; 2009). High quality protein (i.e., complete protein) is determined based on the presence of all 9 EAAs in adequate quantities to support human or animal health. When compared to the biological value (BV) of soybean protein concentrate and milk protein (casein), the BV for proteins recovered from fish processing byproducts using ISP is higher than soybean protein concentrate and similar to milk protein. Egg protein is commonly the reference protein due to its high nutritional quality. Lysine is often considered a limiting EAA; therefore, it needs to be emphasized that proteins recovered from fish processing by-products with ISP had a similar concentration of lysine as whole egg, and the concentration of lysine was even greater in proteins recovered from whole carp and whole krill (Taskaya et al., 2009c; Chen et al., 2009). Furthermore, due to extreme pH shifts during ISP, this technology shows some mild pasteurization effect in the recovered proteins, resulting in inactivation of Escherichia coli and Listeria innocua (Lansdowne, Beamer, Jaczynski, \& Matak 2009a; 2009b).

\section{Functional Properties of Muscle Proteins and their Link to Isoelectric \\ Solubilization / Precipitation and Traditional Surimi Production}

Food preferences by human beings are based primarily on sensory attributes such as texture, flavor, color, and appearance. The sensory attributes of a food are the net effect of complex interactions among various minor and major components of the food. Proteins generally have a great influence on the sensory attributes of foods. For example, the textural and succulence characteristics of meat products are largely dependent on muscle proteins 
(actin, myosin, actomyosin, and several water-soluble meat proteins). "Functionality" of food proteins is defined as "those physical and chemical properties which affect the behavior of proteins in food systems during processing, storage, preparation and consumption" (Morioka, Shimizu, 1989). The most important functional properties when producing a functional muscle protein isolate for use in food are discussed in more detail below.

\subsection{Protein Solubility}

Solubility of protein (or protein extractability) in salt solutions is one of the most important physicochemical properties in the manufacture of muscle food products. Protein solubility is often referred to as functional property or simply functionality. This characteristic is a result of comminuting and mixing of fish muscle tissue with salt. Protein extractability (solubility) is the percent of total protein that enters the solution, but does not sediment due to centrifugation (Tahergorabi et al., 2011). One of the major factors affecting protein solubility in aqueous solutions is the $\mathrm{pH}$ of the solution. Under alkaline and acidic conditions, proteins carry a negative and positive charge, respectively. This leads to repulsion between the proteins which finally cause proteins to be solubilized. On the other hand, because of the fact that proteins carry no net charge at the isoelectric point, they precipitate at this $\mathrm{pH}$. For the isolation of different kinds of proteins from food, solubility difference is considered as an important issue (Kristinsson, 2001). Another factor that affects solubility is denaturation of the proteins. Solubility may decrease when proteins are denatured. According to Sikorski (2007) during heating, denaturation which is followed by aggregation of the proteins leads to an increase in hydrophobicity, and as a result, solubility decreases. The other critical factor which affects protein solubility is the ionic strength of a solution. Ionic strength determines the concentration of ions in a solution. When ionic strength of a salt 
solution is low (i. e. lower than 0.5 ) protein solubility can increase or decrease depending on the amino acid composition on the protein surface. With the increase in ionic strength of a salt solution (i. e. $\mu>1$ ), different ions affect solubility in different ways. For example, for salt solutions containing ions of $\mathrm{SO}_{4}{ }^{2-}$ and $\mathrm{F}^{-}$, solubility decreases with the increase in the salt concentration (Damodaran, 2008). It means that salt solutions containing these ions are able to precipitate proteins from the solution. This concept is refered to 'salting out'. On the other hand, when salt solutions containing ions of $\mathrm{Br}^{-}, \mathrm{I}^{-}, \mathrm{SCN}^{-}$, and $\mathrm{ClO}_{4}^{-}$are added to the protein solution, solubility increases with the increase in the salt concentration. This phenomenon is refered to 'salting in' (Sikorski, 2007). When ionic strength of a solution is kept at a constant amount, protein solubility can either increase or decrease based on the anions and cations which are present in the solution. In this condition, while anions that most increase protein solubility involve $\mathrm{SCN}^{-}>\mathrm{ClO}_{4}^{-}>\mathrm{I}^{-}>\mathrm{Br}^{-}>\mathrm{Cl}^{-}>\mathrm{F}^{-}>\mathrm{SO}_{4}{ }^{2-}$ and cations that most decrease protein solubility include $\mathrm{Ca}^{2+}>\mathrm{Mg}^{2+}>\mathrm{Li}^{+}>\mathrm{Na}^{+}>\mathrm{K}^{+}>\mathrm{NH}^{4+}$. This ranking of anions and cations is according to the Hofmeister series (Damodaran, 2008).

\subsection{Protein Gelation}

A gel is configured by a continuous matrix of interconnected proteins holding water and low- molecular-weight particles (Aguilera, 1992). Sarcoplasmic and connective tissue (stromal) proteins play only a minor role in the overall gelation phenomenon in processed meat. Most sarcoplasmic proteins are readily coagulated when salted meat is cooked to 40$60^{\circ} \mathrm{C}$ and they do not form ordered functional gel structures. On the other hand, myofibrillar proteins as a whole are superior gelling proteins, playing a vital role in producing desirable textural characteristics in processed muscle foods. In particular, myosin (prerigor) or actomyosin (post-rigor) accounts for most of the gel-forming capacity of the myofibril 
protein system. In order to form a gel, myofibrillar proteins must be extracted first, and this is usually initiated by mixing meat with salt $(\mathrm{NaCl}$ or $\mathrm{KCl})$ and phosphates. The process of protein gelation was considered in detail by Ferry (1948). He proposed that two steps were involved; an initial phase in which proteins were thermally denatured with concomitant conformational changes, and a second in which the denatured proteins aggregated. For the second step to proceed, a balance of attractive and repulsive forces is essential. This aggregation process, ultimately responsible for the formation of a three dimensional structure, requires the participating molecules to interact at specific points. The resultant molecular orientation necessary to facilitate these interactions may proceed at a relatively slow rate (Hermansson, 1979). The degree of ordering in gelation is controlled by a number of factors such as thermal treatment. A high heating rate allows insufficient time for molecules to suitably orient themselves, resulting in a discontinuous matrix, uncharacteristic of a gel (Mulvihill \& Kinsella, 1978). Other factors contributing to the nature of gel include protein species, concentration, structure and size, and various processing conditions such as pH and ionic strength and heating rate (Ferry, 1948; Kinsella, 1984). Thus, myosin, which has a large length-to- diameter ratio (approximately $100 \mathrm{~nm}$ in length and 1.5-2 $\mathrm{nm}$ in diameter), can form a highly viscoelastic gel, whereas actin, which is a globular protein of about one-tenth of the myosin size, is a poor candidate for gelation, although it may reinforce myosin gels at a myosin-to-actin ratio (w/w) of about 2:4. Myofibrillar proteins from muscle white fibers form more rigid gels than those from red fibers, and this is attributed to the different physicochemical characteristics existing between myosin isoformes. This explains why chicken pectoralis major, which consists exclusively of white fibers, and its myosin or mixed myofibrillar proteins, forms stronger gels than chicken gastrocnemius (preponderantly 
red fibers) or its proteins under equal meat processing conditions. Another unique property of myofibrillar proteins is that they tend to form the strongest gel at $\mathrm{pH}$ around 6.0, although the exact pH optima vary slightly depending on muscle types and animal species (Ferry, 1948).

The formation of kamaboko has been described by Suzuki (1981) who studied the change in three-dimensional structure as a function of temperature. When fish mince sol (paste) is heated to $50^{\circ} \mathrm{C}$ a loose network (suwari) is formed from actomyosin and myosin molecules; this process is referred to as setting (Suzuki, 1981; Wu, Hamman, \& Lanier, 1985). Setting is species dependent, occurring over a range of temperatures (up to $50^{\circ} \mathrm{C}$ ) and to varying degrees, depending upon the type of fish employed (Taguchi, Kikuchi, Oguni, Tanaka, \& Suzuki, 1978; Niwa et al., 1980, 1981a,b). As the temperature is increased over $45-50^{\circ} \mathrm{C}$, suwari is partially disrupted to form a broken net structure (modori). Again, this process has species dependency (Shimizu, Machida, \& Takenami, 1981). The action of alkaline proteases has been cited as promoting this gel weakening (Lee, 1984). Once the temperature is increased above $65-70^{\circ} \mathrm{C}$ the gel becomes ordered and non-transparent, this stage is referred to as kamaboko (Suzuki, 1981). In this final stage, the cohesiveness and elasticity of the gel is enhanced, the magnitude of which is determined by the slow ordering of the protein network that occurs during setting (Lanier et al., 1982; Niwa et al., 1983a; Autio, Kiesvaara, \& Polvinen, 1989).

\section{Development of Functional Foods from Isoelectrically Recovered Proteins of Seafood and Poultry By-Products}

Diet is an important factor that affects well-being and health. The aim is to have balanced, varied diets containing safer and nutritious foods with pleasant mouthfeel. Factors that have fostered this development include the tremendous current impact of public opinion 
on the relationship between diet and health, the growing life-expectancy of the population (consumers have a high purchasing power and greater health problems and they are very eager to take part in any initiative to keep healthy), more concern with disease prevention, etc (Bech-Larsen, Grunert, 2003).

It is this complex situation that lies behind the spectacular growth in the development of "healthier" products. Such products must possess one of the following characteristics: modified composition and/or processing conditions to prevent or limit the presence of certain potentially harmful compounds, and/or the possibility of including certain desirable substances, either naturally or by addition, with the subsequent added benefits to health. The concept of "healthier" products includes what are known as "functional foods". These are defined as foods that are used to prevent and/or treat certain disorders and diseases, in addition to their nutritional value per se (Bech-Larsen, Grunert, 2003).

Muscle food products are essential in the diet of the developed countries. Their principal components, besides water, are proteins and fats, with substantial contribution of vitamins and minerals of a high degree of bioavaibility. Both meat and its associated products can be modified by adding ingredients considered beneficial for health or by eliminating or reducing components that are considered harmful. In this way, a series of foods can be obtained which, without altering their base, are considered "healthy".

\subsection{Consumers' Trends}

Cardiovascular disease (CVD) is still a major cause of death in Western populations and is becoming an important cause of morbidity and mortality worldwide. Cardiovascular risk can be reduced by lifestyle changes, one of which is diet. Convincing associations for reduced risk of CVD include consumption of fruits (including berries) and vegetables, fish 
and fish oils (eicosapentaenoic acid (EPA) and docosahexaenoic acid (DHA)), foods high in linolenic acid and potassium, as well as physical activity and low to moderate alcohol intake. People who have adopted such diets have benefited by way of a much lower risk of heart disease. However, such a prudent diet is not typical of what consumers in Western countries eat (MCcullough, Feskanich, Rimmeb et al. 2000; MCcullough, Feskanich, Stampfer et al., 2000; Kennedy, Ohls, Carlsons, Fleming, 1995). It appears that consumers today are less likely to invest in long-term health if taste and convenience are compromised: in 1998 only 24 per cent of consumers ate "healthy foods" for long-term prevention of disease, as opposed to 45 per cent in 1990 (Bech-Larsen, Grunert, 2003). However, almost all consumers indicated that they sometimes buy foods for health reasons. Food industries are aware of this, and market some of their foods with health claims. Indeed, it has been shown that health claims on foods have a positive influence on consumers' perception of the healthiness of foods. Thus, functional foods in the form of palatable and ready-to-use foods that suggest short- or long-term health benefits have a huge market and health potential.

In the following section "healthy" and "functional" ingredients that are used to develop functional food products are discussed.

\subsection{The Use of Functional Ingredients in Functional Food Product Development and Meet Dietary Guidelines}

\subsubsection{Functionality of Salt and Dietary Sodium Intake}

Salt has been used since ancient times for the preservation of meat products and is one of the most commonly used ingredients in processed meat products. In modern meat industry salt is used as a flavoring or flavor enhancer with the perceived saltiness mainly due to the $\mathrm{Na}^{+}$with $\mathrm{Cl}^{-}$anion modifying the perception (Ruusunen \& Puolanne, 2005; Miller \& 
Barthoshuk, 1991). Fat and salt jointly contribute to many of the sensory properties in processed meats.

The main source of sodium in meat products is salt $(\mathrm{NaCl})$ and its reduction in meat products is an important goal for decreasing overall dietary sodium. Because salt contributes to water and fat binding in meat products, its reduction has an adverse effect on these parameters increasing cooking loss and weakening the texture (Ruusunen et al., 2001a, 2001b). One of the main functions of salt in processed meats is the solubilization of the functional myofibrillar proteins in meat. This activates the proteins to increase hydration and water-binding capacity, ultimately increasing the binding properties of proteins to improve texture. Increasing the water holding capacity of the meat reduces cooking losses thereby increasing tenderness and juiciness of the meat products. In a comprehensive review on reducing sodium intake from meat products, Ruusunen and Puolanne (2005) put forward two hypotheses to explain the role of $\mathrm{NaCl}$ in water binding in meat. This includes Hamm (1986) who proposed that $\mathrm{Cl}^{-}$ions tend to penetrate in the myofilaments causing them to swell, while Offer and Knight (1988) and Offer and Trinik (1983) claimed that the $\mathrm{Na}^{+}$ions form an ion "cloud" around the filaments. Offer and Knight (1988) based their hypothesis on the selective binding of the $\mathrm{Cl}^{-}$ion to the myofibrillar proteins. According to these authors, this does not cause a marked repulsion between the filaments but between the molecules of myosin filaments breaking down the shaft of the filament. This causes loosening of the myofibrillar lattice. They propose that the swelling induced by $\mathrm{NaCl}$ is entropically rather than electrostically driven.

The effect of $\mathrm{NaCl}$ on meat proteins is most likely caused by the fact that the $\mathrm{Cl}^{-}$ion is more strongly bound to the proteins than the $\mathrm{Na}^{+}$ion. This causes an increase in negative 
charges of proteins. Hamm (1972) concludes that this causes repulsion between the myofibrillar proteins, which results in a swelling of myofibrils due to the repulsions of individual molecules. The absorption of $\mathrm{Cl}^{-}$ions with positively charged groups of myosin results in a shift of the isoelectric point to lower $\mathrm{pH}$, causing a weakening of the interaction between oppositely charged groups at a $\mathrm{pH}$ greater than the isoelectric point and therefore an increase in swelling and water-holding capacity (Hamm, 1986).

Of the many risk factors associated with high blood pressure, the one that has been most investigated is daily sodium intake. It has been studied extensively in animal experimental models, in epidemiological studies, controlled clinical trials and in population studies on restricted sodium intake (Gibbs, Lip, \& Beevers, 2000; Law, Frost, \& Wald, 1991). Current average salt intake in Western populations is 9-12 g/day (He, \& Macgregor, 2003) and this should be reduced to 5-6 g/day according to most public health recommendations aimed at lowering blood pressure (Alderman, \& Cohen, 2002; Havas, Roccella, \& Lenfant, 2004). One of the biggest barriers to salt replacement is cost as salt is one of the cheapest food ingredients available. Also, consumers have grown accustomed to salt through processed foods so in some cases it has being difficult to remove as previously discussed. However, apart from lowering the level of salt added to products there are currently three major approaches to reduce the salt content in processed foods. Firstly, and probably the most widely used is the use of salt substitutes, in particular, potassium chloride $(\mathrm{KCl})$. Masking agents are commonly used in these products. A meta-analysis of randomized controlled trials showed that potassium supplements reduced mean blood pressures (systolic/diastolic) by 1.8/1.0 $\mathrm{mmHg}$ in normotensive subjects and 4.4/2.5 $\mathrm{mmHg}$ in hypertensive subjects (Whelton et al. 1997). Several large cohort studies have found an inverse association between 
potassium intake and risk of stroke (Ascherio et al, 1998; Khaw, \& Barrett-Connor, 1987). Therefore, potassium supplements have been shown to have protective effects on blood pressure and cardiovascular diseases. Secondly, the use of flavor enhancers which do not have salty taste, but enhance the saltiness of products when used in combination with salt. This allows less salt to be added to the products. Thirdly, optimizing the physical forms of salt so that it becomes more taste bioavailable and therefore less salt is needed (Angus, Phleps, Clegg, Narain, \& Kilcast, 2005).

\subsubsection{Polyunsaturated Fatty Acids as Functional Ingredients}

Fat is an essential component of the diet (Burr \& Burr, 1929), and the fatty acids have different roles in the human body. In the 1970s, Danish researchers discovered that Greenland Inuits, who consume large amounts of marine lipids as part of their native lifestyle, had a much lower cardiovascular mortality (10-30 per cent) compared with the Danes, who consume much lower levels of these lipids (Kromann and Green, 1980; Bjerregaard \& Dyerberg, 1988). These findings triggered new research on the role of the long-chain polyunsaturated fatty acids (LC PUFA) in the development of cardiovascular disease and on the possibilities of utilizing the beneficial effects of $\omega-3$ LC PUFA by incorporating marine lipids into foods.

There are two distinct families of PUFA that cannot be inter-converted. The parent fatty acids of the $\omega-6$ (linoleic acid) and $\omega-3$ ( $\alpha$-linolenic acid) families are essential fatty acids as they cannot be synthesized by the human body. The body is able to synthesize the LC PUFA from the parent fatty acids. However, linoleic acid and $\alpha$-linolenic acid are competing for the same enzyme systems for the synthesis and, therefore, it is important that there is the right balance between the intake of $\omega-6$ and $\omega-3$ fatty acids. The $\omega-6$ PUFA are found mainly in 
vegetable products. The parent $\omega-3$ fatty acid $\alpha$-linolenic acid, is also present in some vegetables (flaxseed, rapeseed, soybean and nut oils), but fish and marine animals are the best sources of the $\omega-3$ LC PUFA, eicosapentanoic acid (EPA) and docosahexanoic acid (DHA) (Anselmino and Hornstra, 2000). Low levels of $\omega-3$ LC PUFA are also found in meat. The current intake of $\omega-3$ PUFA in industrialized countries is only 4-10 per cent of the intake of $\omega-6$ PUFA, compared with an estimated ratio of 1:1 about 150 years ago (Leaf \& Weber, 1987). Therefore, several bodies have issued PUFA guidelines to encourage a more balanced ratio of $\omega-6 / \omega-3$ fatty acids that would optimize the benefits of both fatty acids. Several large-scale epidemiological studies have demonstrated a negative association between fish consumption and cardiovascular and/or overall mortality. The cardio-protective effect of fish consumption seems to be more prevalent in high-risk populations.

Several mechanisms have been suggested to explain the preventive effect of $\omega-3$ LC PUFA on cardiovascular diseases. It is now well established that $\omega$-3 LC PUFA reduce triglyceride levels by lowering hepatic triglyceride synthesis and by decreasing the release of triglyceride-rich very low-density lipoproteins (VLDLs) into the blood (Weber \& Raederstorf, 2003; Nenseter, Rustan, Lundhatz, Soyland, Maelandsmo, Phillips \& Devon, 1992; Bordin , Bodamer, Venkatesan , Gray , Bannister \& Halliday, 1998; Haglund, Wallin , Wretling, Hultberg \& Saldeen, 1998). A high plasma triglyceride level is a cardiovascular risk factor. Hypertension is another important cardiovascular risk factor. High doses of $\omega-3$ LC PUFA have been shown to reduce hypertension, probably by influencing membrane fluidity and the balance of the prostanoids that control the constriction and dilation of the small arteries and arterioles. Numerous studies have shown that $\omega-3$ LC PUFA have antiaggregant activity (Hirai, Teran, Makuta, Ozawa, Fujita, Tamura \& Yoshida, 1989). This is 
probably due to EPA's role in the eicosanoid synthesis and its ability to reduce the levels of arachidonic acid (AA) in the membrane. EPA is a precursor of the 3-series prostanoids thromboxaneA3 (TXA3) and prostaglandinI3 (PGI3) while AA is a precursor of TXA2 and PGI2. TXA2 and TXA3 are both prothrombotic, but TXA3 is less prothrombotic than TXA2. In contrast, PGI2 and PGI3 are equally antithrombotic. Moreover, it seems that EPA and DHA reduce the gene expression of the enzymes involved in eicosanoid synthesis (Lemaitre, Vericel, Polette, \& Lagarde, 1997; Kraemer, Stevens, Grimminger \& Seeger, 1996).

Apart from the nutritional value of these oils, many types of oils are used to improve the texture and increase the whiteness of surimi seafood. Flavor perception is decreased when vegetable oils are used because they decrease the vapor pressure of many of the flavor's components due to their affinity toward the oil. However, flavor release is prolonged, giving the product a more rounded flavor profile. Furthermore, chemicals that tend to evaporate quickly are retained within the oil phase of surimi seafood products and thereby increase the shelf life of the product (Manley, Mankoo, \& Dubosc, 2005).

Soybean and canola oils are commonly used in surimi-based crabmeat as a texture modifier, color enhancer, or processing aid. Lee \& Abdollahi (1981) suggested that the addition of oil/fat modified the texture of fish protein gels in the following manner: it prevents sponge-like texture development during extended frozen storage; reduces brittleness; and minimizes textural variations resulting from cooking. Vegetable oil can replace water by 1:1 up to $6 \%$ without changing the shear stress and shear strain values. A formula that contains $36 \%$ water, $30 \%$ surimi, and $34 \%$ remaining ingredients can therefore perform similarly to a formula that contains $30 \%$ surimi, $30 \%$ water, $6 \%$ vegetable oil, and $34 \%$ remaining ingredients. Substituting oil for water gives surimi seafood manufacturers the 
option to keep surimi as the number-one ingredient for a product containing less than $30 \%$ surimi. Vegetable oil also makes products whiter through a light scattering effect that results from the emulsion that is created when oil is comminuted with surimi proteins and water. As the percentage of oil increased, the lightness and yellow hue linearly increased as well. In addition, vegetable oil is often used as a processing aid on the cooking machine, especially when the paste becomes sticky due to increased starch content in the formula.

\subsubsection{Titanium Dioxide $\left(\mathrm{TiO}_{2}\right)$}

Titanium dioxide is an approved color agent for use in food by the European Union, by the United States FDA and by Codex Alimentarius of the FAO/WHO. The joint WHO/FAO Expert Committee of Food Additives (JECFA) evaluated $\mathrm{TiO}_{2}$ and allocated an Acceptable Daily Intake not specified (JECFA, 1986).

$\mathrm{TiO}_{2}$ can be manufactured to form two crystal structures, anatase and rutile. The rutile form can be formed into platelets on mica (potassium aluminum silicate) template which is removed by extractive dissolution in acid and then alkali. The layer thickness of the rutile form of titanium dioxide determines the color of the product. Rutile $\mathrm{TiO}_{2}$, platelet form is currently used in aqueous film coating system for commercial confectionary products in United States (Lomer, Thompson, Commisso, Keen, \& Powell, 2000).

$\mathrm{TiO}_{2}$ is the whitest and brightest known pigment and, in foods, it provides a basic white background color that acts as an opacifier and reflects light across most of the visible spectrum. It may also act as a barrier by physically separating other colors.

When $\mathrm{TiO}_{2}$ is used, careful $\mathrm{pH}$ measurement is required. At higher levels of $\mathrm{TiO}_{2}(0.2 \%)$, the $\mathrm{pH}$ of the meat approaches 6.7 or below. At these conditions, fish proteins do not form an elastic gel during crabstick production and the sheet of surimi paste keeps breaking, resulting 
in reduced yield. $\mathrm{CaCO}_{3}$ and $\mathrm{TiO}_{2}$ showed the ability to make opaque surimi gels. $\mathrm{TiO}_{2}$ was much stronger than $\mathrm{CaCO}_{3}$. In addition, $\mathrm{CaCO}_{3}$ at $1.5 \%$ was not as strong as $0.02 \% \mathrm{TiO}_{2}$ for the $\mathrm{L}^{*}$ value. Lightness $\left(\mathrm{L}^{*}\right)$ increased from 75.5 to 78.4 with a level of $1.5 \% \mathrm{CaCO}_{3}$ and to 84.9 with $0.08 \% \mathrm{TiO}_{2}$. For this experiment with $\mathrm{CaCO}_{3}$ and $\mathrm{TiO}_{2}$, shear stress (30.2 to 33.8), shear strain (2.45 to 2.63$)$, and $\mathrm{pH}$ (7.03 to 7.23$)$ values remained consistent, indicating they did not affect texture at the level used (Park, 2005).

\section{Physicochemical Evaluations of the Developed Food Products}

\subsection{Textural Properties}

Texture and mouthfeel remains the ultimate criteria of product acceptability by the consumer. Food industry efforts are to develop the proper texture for food products (Rohm, 1990; Gunasekaran \& Ak, 2003). According to the International Organization for Standardization, texture of a food is defined as the rheological and structural attributes of a food product which is perceived by human senses (ISO, 1992). There are different methods that can be used to measure texture, each of which provides slightly different information: Texture Profile Analysis (TPA), Kramer shear and torsion test. Torsion test is considered a fundamental test where results are objective while Kramer shear and TPA are considered empirical tests which characterize results so that they can be directly related to overall acceptance or hedonic ratings (Kim \& Park, 2005). Therefore, when all three methods are employed, a more complete picture is obtained.

\subsubsection{Texture Profile Analysis (TPA)}

Textural properties of a material are measured by a technique called textural profile analysis. According to Mallikarjunan (2006), cohesiveness, springiness, chewiness, resilience, gumminess and hardness are the textural attributes which are measured by the 
utilization of TPA technique. Definition of these parameters is important because each factor deals with different aspects of a material's texture. Hardness is measured as the maximum force $(\mathrm{N})$ detected during first compression. Cohesiveness is measured as the ratio of the positive force during the second compression to the positive force during the first compression and determines the amount of deformation for a material before it breaks. Gumminess is determined as the product of hardness $x$ cohesiveness. Springiness is measured as the ratio of the distance from the second area to the second probe reversal over the distance and it is the ability of a material to recover its original shape after the removal of the force. Chewiness is defined as the energy required to chew a solid food to the point required for swallowing it and is calculated as gumminess $\mathrm{x}$ springiness. Resilience is determined as the degree of how well a sample recovers from deformation in relation to speed and force applied (Alvarez, Canet, \& Lopez, 2002). Cohesiveness, gumminess, springiness, chewiness, and resilience do not have units.

\subsubsection{Torsion Test}

A torsion test has been proposed as an objective method to measure the mechanical properties of surimi gels, which could be applied to other gelling foods. This method allows the determination of shear stress and shearing strain at failure. Shear stress measures gel strength and correlates well with sensory hardness, TPA hardness, and TPA fracturability. This parameter can be improved by different processing conditions and additives. Shear strain measures the gel deformability and correlates well with cohesiveness and springiness (TPA). This parameter highly depends on the fish species and freshness; generally, it is not improved by process or additives. A surimi gel with a shear strain value higher than 2.2 is considered high quality and can be used for producing crab or shrimp analogues. Surimi gels 
with strain values lower than 1.8 are considered low quality (Hamman \& Lanier, 1987; Kim, Hamman, Lanier, \& Wu, 1986). Most fish species from warm water produce surimi gels with low to medium shear stress and low shear strain values. These gels are perceived as "mushy" (low stiffness and low cohesiveness) and have low commercial value (Luo, Kuwahara, Kaneniwa, Murata, \& Yokoyama, 2001; Ramírez, Garcia-Carreno, et al., 2002; Ramirez, Santos, et al., 2000).

\subsubsection{Kramer Shear Force}

A comprehensive description of the Kramer cell can be found in Bourne (2002). A typical system contains 10 shear blades that are $3.2 \mathrm{~mm}$ thick and separated by a distance equal to thickness. The sample holder is filled with the food. Shear blades are forced through the material until they pass through the bars in the bottom of the sample container. Force on the ram holding the blades is measured over time and correlated to the firmness of the product. Parameters usually measured include maximum force at a given sample weight, slope, and energy of the force-deformation curve. Some food products do not display a linear relationship between maximum force and sample weight, and thus it has been advised to use a constant weight of sample in the test cell unless a linear relationship is demonstrated between sample weight and maximum force for that food (Bourne, 2002). A highly linear relationship has been shown for surimi, in the range 5-14 $\mathrm{g}$ when samples are cut in parallelepipeds of $1 \mathrm{~cm}$ height, and with lengths and widths varying from 4 to $7 \mathrm{~cm}$ and 1 to $2 \mathrm{~cm}$ respectively. However, this linear relationship was not found for fillets. Thus, a constant weight is preferred for these fish samples (Betti \& Fletcher, 2005).

\subsection{Rheology}


The physical approach to define mechanical behavior is called rheology. Rheology is the science of material deformation and flow. Because action of force results in deformation and flow in the material, the mechanical properties will be referred to as rheological properties. In addition, rheology considers the time effect during the loading of a body. Thus, mechanical behaviors of a material, such as time-dependent stress and strain behavior, creep, stress relaxation, dynamic mechanical modulus, and viscosity, are expressed in terms of three parameters: force, deformation, and time.

Dynamic mechanical analysis (DMA) is a method which is used to study dynamic viscoelastic behavior (DVB) of a material. For this purpose, dynamic or oscillatory tests are performed. During DMA, dynamic stress at a given frequency is applied to a material. Viscoelastic materials show both elastic (solid) and viscous (liquid) behaviors. The rheological factors which show DVB of the material, includes the storage modulus ( $\left.\mathrm{G}^{\prime}\right)$, the loss modulus ( $\left.\mathrm{G}^{\prime \prime}\right)$, and loss angle (Tan delta). The storage modulus $\left(\mathrm{G}^{\prime}\right)$ is related to the elastic (solid) character of the material which indicates the energy which is stored during deformation (Peleg, Roy, Campanella, \& Normand, 1989; Hamann et al., 1990). On the other hand, the loss modulus $\left(\mathrm{G}^{\prime \prime}\right)$ is related to the viscous (liquid) behavior of the material which indicates the energy which is dissipated as the material is deformed (Vodovotz, Baik, Vittadini, \& Chinachoti, 2001). For example, if we assume a solid which is ideally elastic, all the energy is stored (i.e. $G "=0$ ) but for a viscous material in which all the energy is dissipated, G' is equal to zero. Tan delta, which is defined as the ratio of G"/G' (Dogan \& Kokini, 2007), shows the degree of viscoelasticity of a sample. If tan delta is a low value for a material, it means that the material has a higher elasticity (higher $\mathrm{G}^{\prime}$ value) and is a more solid-like material. 


\subsection{Color properties}

Color is an important meat quality which greatly affects consumers' preference (Froning, 1995). Total heme pigments including myoglobin and hemoglobin are responsible for the color of meat. The meat pigment is mainly myoglobin because hemoglobin, which is the blood pigment, will be mostly removed after slaughter. Therefore, myoglobin is the determining factor for the meat color, and variations in meat color indicate the differences in myoglobin content. For example, poultry breast and thigh which are known as white and dark meat respectively easily can be differentiated from each other (Schwartz, Elbe, \& Giusti, 2009). Since myoglobin and hemoglobin contain iron, the difference in iron content of white and dark chicken meat is the result of variations in total heme pigments The CIE L*a*b* color scale which is based on the values of redness ( $\left.a^{*}\right)$, yellowness $\left(b^{*}\right)$, and lightness ( $\left.\mathrm{L}^{*}\right)$ is a well-known method for measuring the color of a sample. In this regard, the moisture content of the sample is an important factor influencing the color measurements. If the sample has more water content, because of the greater light reflection, it will have more lightness value.

The factors influencing the color of the recovered proteins are those associated with the raw starting material such as the amount of pigments, blood, and dark muscle. Therefore, different processes should be applied to different fish species for obtaining the lightest (in color) possible protein isolates, because consumers preferred the whitest color for the protein isolates (Tabilo-Munizaga \& Barbosa-Canovas, 2004). This shows that color is an important factor which affects consumers' selection for the products made from isolated proteins. The results from comparative studies performed on surimi, acid and alkali process indicated the maximum whiteness value for the protein isolates obtained from the surimi process, followed 
by alkali and acid processes. According to Nolsøe and Undeland (2009) the greater whiteness value in surimi production could be explained by the washing process which might have helped to remove higher amounts of heme pigments from the protein isolate. The higher whiteness value for the proteins recovered by alkaline solubilization processes compared to the ones obtained from the acid solubilization process indicated that alkali aided process was more efficient in the heme pigments' separation from the fish meat.

\subsection{Protein Denaturation}

In food processing, denaturation is defined as an irreversible change which occurs when proteins unfold and hydrophobic amino acids, which are originally located in the interior of the protein molecule, are exposed. A number of factors cause protein denaturation such as change in $\mathrm{pH}$ (by the addition of alkali or acid) and temperature (i.e. cooking), or addition of ions (e.g. $\mathrm{NaCl}$ ). Denaturation affects a number of factors such as solubility and hydrophobicity of the proteins (Sikorski, 2007). There will be a decrease in solubility as well as an increase in hydrophobicity of the denatured proteins compared to the native state. Denaturation of meat proteins occurs at the temperature range of $30-55^{\circ} \mathrm{C}$. For example, the denaturation temperature for myosin is $50-55^{\circ} \mathrm{C}$ (Smyth, O’Neill, \& Smith, 1999). According to Wang and Smith (1993) and Smyth et al. (1999) the denaturation temperature of myosin varies with $\mathrm{pH}$ and ionic conditions. A $\mathrm{pH}$ of 5.5-6.1 and ionic strength of $0.6 \mathrm{M}$ $\mathrm{NaCl}$ are the typical conditions used in processed meat industry.

Differential scanning calorimetry (DSC) is typically employed to study thermal transitions of proteins in biochemical systems such as food. Thermally-induced transitions of protein structure are recorded as a differential heat flow that is displayed as peaks on a DSC thermogram. For proteins, the thermally-induced transition is the structural melting or 
unfolding of the molecule that initiates denaturation (Mallikarjunan, 2006). Change in enthalpy (i.e., heat input) during thermal denaturation of proteins is mainly attributed to the rupture of intramolecular hydrogen bonds (Park, 2005). This reaction is detected as an endothermic peak and the net heat energy (enthalpy, $\Delta \mathrm{H}$ ) required to rupture the bonds is represented by the area under the peak. 


\section{References}

Aguilera, J.M. (1992). Generation of engineered structures in gels. In Schwartzburg, H.G., \& Hartel, R.W, (Ed), Physical chemistry of foods, (p. 387-421), New York. Marcel Decker.

Angus, F., Phelps, T., Clegg, S., Narain, C. den Ridder, C., \& Kilcast, D. (2005). Salt in processed foods: Collaborative Research Project. Leatherhead Food International.

Alderman, M.H., \& Cohen, H.W. (2002). Impact of dietary sodium on cardiovascular disease morbidity and mortality. Current Hypertension Report, 4, 453-7.

Alvarez, M.D., Canet, W., \& Lopez, M.E. (2002). Influence of deformation rate and degree of compression on textural parameters of potato and apple tissues in texture profile analysis. European Food Research and Technology, 215, 13-20.

Anselmino C \& Hornstra G. (2000). "Omega-3 long-chain polyunsaturated fatty acids and health benefits", http:// www.nutrivit.co.uk/professional/PDFs/Omega_3\%20book.pdf.

Ascherio, A. et al. (1998). Intake of potassium, magnesium, and fiber and risk of stroke among US men. Circulation, 98, 1198-1204.

Autio, K., Kiesvaara, M. \& Polvinen, K. (1989). Heat-induced gelation of minced rainbow trout (salmo gairdneri): effect of pH, sodium chloride and setting. Journal of Food Science, 54, 805.

Barbut, S. (2002). Basic anatomy and muscle biology, Poultry products processing. (p. 494 \& 510). CRC Press, Boca Raton, (FL): Taylor and Francis Group.

Bech-Larsen, T., \& Grunert, K.G. (2003). The perceived healthiness of functional foods. A conjoint study of Danish, Finnish and American consumers' perception of functional foods. Appetite, 40, 9-14.

Betti, M., \& Fletcher, D. L. (2005). The influence of extraction and precipitation $\mathrm{pH}$ on the dry matter yield of broiler dark meat. Poultry Science, 84, 1303-1307.

Bjerregaard, P., \& Dyerberg, J. (1988). Mortality from ischaemic heart disease and cerebrovascular disease in Greenland. International Journal of Epidemiology, 17 514-19.

Bordin, P., Bodamer, O.A. F., Venkatesan, S., Gray, R. M., Bannister, P.A., \& Halliday, D. (1998). Effects of fish oil supplementation on apolipoprotein B100 production and lipoprotein metabolism in normolipidaemic males. European Journal of Clinical Nutrition, 58, 104-9.

Bourne, M.C. (2002) Food texture and viscosity: concept and measurement. Food Texture and Viscosity: Concept and Measurement. Academic Press, London, pp. 423.

Burr, G.O., \& Burr, M.M. (1929). A new deficiency disease produced by the rigid exclusion of fat from the diet. Journal of Biological Chemistry, 82, 345-67. 
Chen, Y.C., \& Jaczynski, J. (2007). Protein recovery from rainbow trout (Oncorhynchus mykiss) processing by-products via isoelectric solubilization / precipitation and its gelation properties as affected by functional additives. Journal of Agricultural and Food Chemistry, 55, 9079-88.

Chen, Y. C., Tou, J. C., \& Jaczynski, J. (2009). Amino acid and mineral composition of protein and other components and their recovery yields from whole Antarctic krill (Euphausia superba) using isoelectric solubilization/precipitation. Journal of Food Science, 74(2), H31-H39.

Choi, Y. J., \& Park, J.W. (2002). Acid-aided protein recovery from enzyme-rich Pacific whiting. Journal of Food Science, 67, 2962-2967.

Connell, J.J. (1980). Advances in fish science and technology, Fishing News Books Ltd., Farnham

Damodaran, S. (2008). Amino acids, peptides, and proteins. In S. Damodaran, K. L. Parkin, \& O. R. Fennema(Eds.), Fennema's Food Chemistry ( $4^{\text {th }}$,ed.).(p.268). CRC Press, Boca Raton, (FL): Taylor and Francis Group.

Dogan, H., \& Kokini. J. L. (2007). Rheological properties of foods. In D. R. Heldman, \& D. B. Lund, (Ed,) Handbook of Food Engineering ( $2^{\text {nd }}$ ed.).(p. 13). CRC Press, Boca Raton, FL.

Falch, E., Rustad , T., \& Jonsdottir, R. et al. (2006). Geographical and seasonal differences in lipid composition and relative weight of by-products from gadiform species. Journal of Food Composition and Analysis, 19, 727-736.

FAO. (2011). Global aquaculture production. [Internal document] URL available at http://www.fao.org/fishery/statistics/global-aquaculture-production/en (accessed 10 October 2011).

Ferry, J.D. (1948). Protein gels. Advanced Protein Chemistry, 3, 1.

Fletcher, D. L. (1997). Poultry meat color. In Proceeding of Poultry Science Symposium. (p. 159-175). Poultry and Meat Science. University of Bristol, Bristol, UK.

Froning, G. W. (1995). Color of poultry meat. Poultry and Avian Biology Reviews, 6, 83-93.

Gehring, C. K., Gigliotti, J. C., Moritz, J. S., Tou, J. C., \& Jaczynski, J. (2010). Functional and nutritional characteristics of proteins and lipids recovered by isoelectric processing of fish byproducts and low-value fish-a review. Food Chemistry, 124(2), 422-431.

Gibbs, C.R., Lip, G.Y., \& Beevers, D.G. (2000).Salt and cardiovascular disease: clinical and epidemiological evidence. Journal of Cardiovascular Risk, 7, 9-13.

Guenneugues \& Morrissey. (2005). Surimi resources. In Park, J.W., (Eds.). Surimi and Surimi seafood. ( ${ }^{\text {nd }}$ ed). (p. 3-32). Boca Raton, FL: Taylor \& Francis Group 
Guerard, F., Sellos, D. \& Le Gal, Y. (2005). Fish and shellfish upgrading, traceability. In :Adv. Biochem, Engin,/Biotecnol (edited by R. Ulber \& Y. Le Gall). (p. 127-163). Berlin/Heidelberg: Springer.

Gunasekaran, S., \& Ak, M. M. (2003). Cheese texture. In Gunasekaran, \& Ak, M. M. (Ed), Cheese Rheology and Texture. CRC Press, Boca Raton, FL.

Haglund, O., Wallin, R., Wretling, S., Hultberg, B., \& Saldeen, T. (1998). Effects of fish oil alone and combined with long chain $(\omega-6)$ fatty acids on some coronary risk factors in male subjects. Journal of Nutritional Biochemistry, 9, 629-35.

Hamm, R. (1986). Functional properties of the myofibrillar system. In P. J. Bechtel (Ed.), Muscle as food (pp. 135-200). New York: Academic Press.

Hamm, R. (1972). Importance of meat water binding capacity for specific meat products. In Kolloidchemie des Fleisches (pp. 215-222). Germany: Parey Publishing

Hamann, D. D., Purkayastha, S. \& Lanier. T. C. (1990). Applications of thermal scanning rheology to the study of food gels. In R. Harwalkar, \& C. Y. Ma (Ed) Thermal Analysis of Foods. (p. 306), Elsevier, New York, NY.

Hamman, D. D., \& Lanier, T. C. (1987). Instrumental methods for predicting seafood sensory texture quality. In D. E. Kramer, \& J. Liston (Eds.), Seafood quality determination, (pp. 123136). Amsterdam, Netherlands: Elsevier Science Publishers BV.

Havas, S., Roccella, E.J., \& Lenfant, C. (2004). Reducing the public health burden from elevated blood pressure levels in the United States by lowering intake of dietary sodium. American Journal of Public Health, 94, 19-22.

HE, F.J., \& Macgregor, G.A. (2003). How far should salt intake be reduced? Hypertension; 42, 1093-9.

Hermansson, A.M. (1997). Aggregation \& denaturation involved in gel formation. In A. PourEl(Ed.). Functionality and Protein structure. (p.81). American Chemical Society, Washington.

Hirai, A., Terano, T., Makuta, H., Ozawa, A., Fujita, T., Tamura, Y., \& Yoshida, S. (1989). Effect of oral administration of highly purified eicosapentaenoic acid and docosahexaenoic acid on platelet function and serum lipid in hyperlipidemic patients. Advances in Prostaglandin Thromboxane and Leukoterine Research, 19, 627-30.

Hultin, H. O., \& Kelleher, S. D. (1999). Process for isolating a protein composition from a muscle source and protein composition. Patent US6005073.

Hultin, H. O., \& Kelleher, S. D. (2000). Surimi processing from dark muscle fish. In J. W. Park (Ed.), Surimi and surimi seafood (pp. 59-77). New York: Marcel Dekker 
Hultin, H. O., \& Kelleher, S. D. (2001). Process for isolating a protein composition from a muscle source and protein composition. Patent US6288216.

Hultin, H. O., \& Kelleher, S. D. (2002). Protein composition and process for isolating a protein composition from a muscle source.Patent US6451975.

ISO (International Organization for Standardization). (1992). Sensory Analysis-Vocabulary. ISO5492.

JECFA. (1986). Thirtieth Report of the Joint FAO/WHO Expert Committee on Food Additives FAO Nutrition Meetings Report Series WHO Technical Report Series, FAS 70.36/ NMRS 46AJECFA $13 / 55$ to titanium dioxide (INS 171)

Kelleher, S. D., \& Hultin, H. O. (2000). Functional chicken muscle protein isolates prepared using low ionic strength, acid solubilization/precipitation. In Reciprocal meat conference; meat science the new millennium (pp. 76-81). Savoy, IL: American Meat Science Association.

Kennedy, E.T., OHL, S.J., Carlson, S., \& Fleming K. (1995). The Healthy Eating Index: design and applications. Journal of American Dietetic Association, 95, 1103-8.

Khaw, K.T., \& Barrett-Connor, E. (1987). Dietary potassium and stroke-associated mortality. A12-year prospective population study. New England Journal of Medicine, 316,235--240.

Kim, Y. S., Park, J. W., \& Choi, Y. J. (2003). New approaches for the effective recovery of fish proteins and their physicochemical characteristics. Fisheries Science, 69(6), 1231-1239.

Kim, B. Y., Hamman, D. E., Lanier, T. C., \& Wu, M. C. (1986). Effects of freeze-thaw abuse on the viscosity and gel-forming properties of surimi from two species. Journal of Food Science, 51(4), 951-956.

Kinsella, J.E. (1948). Functional properties of food proteins: thermal modification involving denaturation and gelation. In research in food science and nutrition, ed. J. McLoughlin. Boole Press, Dublin, P.226.

Kraemer, H. J., Stevens, J., Grimminger, F., \& Seeger, W. (1996).Fish oil, fatty acids and human platelets: dose dependent decrease in dienoic and increase in trienoic thromboxane generation. Biochemical Pharmacology, 52, 1211-17.

Kristinsson, H. G. (2001). Conformational and functional changes of hemoglobin and myosin induced by pH: Functional role in fish quality. PhD Diss. Univ. Massachusetts, Amherst.

Kristinsson, H.G., Theodore, A.E., Demir, N., \& Ingadottir, B. A. (2005). Comparative study between acid- and alkali-aided processing and Surimi processing for the recovery of proteins from channel catfish muscle. Journal of Food Science, 70, C298-C306. 
Kristinsson, H. G., \& Hultin, H. O. (2003). Changes in conformation and subunit assembly of cod myosin at low and high $\mathrm{pH}$ and after subsequent refolding. Journal of Agricultural and Food Chemistry, 51(24), 7187-7196.

Kromann, N., \& Green, A. (1980). Epidemiological studies in the Upernavik district, Greenland, Acta Med Scand, 208, 401-6.

Lanier, T.C., Lin, T.S., Liu, Y.M. \& Hamann, D.D. (1982). Heat Gelation properties of actomyosin and surimi prepared from Atlantic croaker. Journal of Food Science, 47, 19-21.

Lansdowne, L., Beamer, S., Jaczynski, J., \& Matak, K. E. (2009a). Survival of Escherichia coli after isoelectric solubilization/precipitation of fish. Journal of Food Protection, 72(7), 13981403.

Lansdowne, L., Beamer, S., Jaczynski, J., \& Matak, K. E. (2009b). Survival of Listeria innocua after isoelectric solubilization and precipitation of fish protein. Journal of Food Science, 74(4), M201-M205.

Law, M.R., Frost, C.D., \&Wald, N.J. (1991). By how much does salt reduction lower blood pressure? III--Analysis of data from trials of salt reduction. British Medical Journal, 302,819824.

Lee, C.M. \& Abdollahi, A. (1981). Effects of hardness of plastic fat on structure and material properties of fish protein gels. Journal of Food Science, 46, 1755-1759.

Leaf, A., \& Weber, P.C. (1987). A new era for science in nutrition. American Journal of Clinical Nutrition, 45 (5) 1048-1053.

Lemaitre, D., Vericel, E., Polette, A., \& Lagarde, M. (1997). Effects of fatty acids on human platelet glutathione peroxidase: possible role of oxidative stress, Biochemical Pharmacology, 53 479-86.

Liang, Y., \& Hultin, O. H. (2003). Functional protein isolates from mechanically deboned turkey by alkaline solubilization with isoelectric precipitation. Journal of Muscle Food, 14, 195-205.

Lomer, M. C.E., Thompson, R. P.H. Commisso, J., Keen, C. L., \& Powell. J.J. (2000). Determination of titanium dioxide in foods using inductively coupled plasma optical plasma optical emission spectroscopy. The Analyst, 2339-2343.

Luo, Y. K., Kuwahara, R., Kaneniwa, M., Murata, Y., \& Yokoyama, M. (2001). Comparison of gel properties of surimi from Alaska pollock and three freshwater fish species: effects of thermal processing and protein concentration. Journal of Food Science, 66, 548-554.

Mallikarjunan, P. (2006). Physical measurements. In D. W. Sun. (Ed), Handbook of Frozen Food Processing and Packaging. (p.528) CRC Press, Boca Raton, FL. 
Manley, C, Mankoo, A \& Dubosc, V. (2005). Surimi Seafood Flavors. In J. W. Park, Surimi and Surimi Seafood, $\left(2^{\text {nd }} e d\right)$. (p 710-745). Boca Raton (FL): Taylor and Francis Group.

MCcullough, ML, Feskanich, D, \& Rimmeb, et al. (2000). Adherence to the Dietary Guidelines for Americans and risk of major chronic disease in men. American Journal of Clinical Nutrition, 72, 1223-31.

MCcullough, ML, Feskanich, D, \& Stampfer, M.J. et al. (2000). Adherence to the Dietary Guidelines for Americans and risk of major chronic disease in women. American Journal of Clinical Nutrition, 72, 1214-22.

Meinke, W.W., Rahman, M.A., \&Mattil, K.F. (1972). Some factors influencing the production of protein isolates from whole fish. Journal of Food Science, 37, 195-8.

Meinke, W.W., \& Mattil, K.F. (1973). Autolysis as a factor in the production of protein isolates from whole fish. Journal of Food Science, 38, 864-6.

Miller, I. J., \& Barthoshuk, L. M. (1991). Taste perception, taste bud distribution and spatial relationship. In T. V. Geychell, R. L. Doty, L. M. Barthoshuk, \& J. B. Snow (Eds.), Smell and taste in health disease (pp. 205-233). New York: Raven Press.

Mireles DeWitt, C. A., Nabors, R. L., \& Kleinholz, C. W. (2007). Pilot plant scale production of protein from catfish treated by acid solubilization/isoelectric precipitation. Journal of Food Science, 72, E351-E355.

Mireles DeWitt, C. A., Gomez, G., \& James, J. M. (2002). Protein extraction from beef heart using acid solubilization. Journal of Food Science, 67, 3335-3341.

Morioka, K., Shimizu, Y. (1989). Contribution of sarcoplasmic proteins to gel formation of fish meat. Japanese Journal of Fisheries, 56: 929-33.

Mulvihill, D.M. \& Kinsella, J. E. (1987). Gelation characteristics of whey proteins and betalactoglubin. Food Technology, 41, 102.

Nenseter, M., Rustan, A.C., Lundhatz, S., Soyland, E., Maelandsmo, G., Phillips, M. C., \& Devon, C. A. (1992). Effect of dietary supplementation with n-3 polyunsaturated fatty acids on physical properties and metabolism of low density lipoprotein in humans, Atheroscler Thromb, 12, 369-79.

Niki, H., Kato, T., Deya, E., \& Igarashi, S. (1985). Recovery of protein from effluent of fish meat in producing surimi and utilization of recovered protein. Japanese Journal of Fisheries, 51(6), 959-964.

Niwa, E., Koshiba, K., Matsuzaki, M., Nakayama, T. \& Hamada, I. (1980). Species-specificities of myosin heavy chain in setting and returning. Bulletin of the Japanese Society of Scientific Fisheries, 46, 1497. 
Niwa, E., Nakayama, T. \& Hamada, I. (1981a). Arylsulfonyl chloride induced setting of dolphin fish sol. Bulletin of the Japanese Society of Scientific Fisheries, 47, 179.

Niwa, E., Sato, J., Suzuki, R., Nakayama, T. \& Hamada, I. (1981b). Flourometric study of setting properties of fish flesh sol. Bulletin of the Japanese Society of Scientific Fisheries, 47, 817.

Niwa, E., Nakayama, T. \& Hamada, I. (1983a). effect of setting on the network structure of protein in fish flesh gel. Bulletin of the Japanese Society of Scientific Fisheries, 49, 245.

Nolsoe, H., \& Undeland, I. (2009). The acid and alkaline solubilization process for the isolation of muscle proteins: state of the art. Food and Bioprocess Technology, 2, 1-27.

Offer, G., \& Knight (1988). The structural basis of water-holding in meat. In R. A. Lawrie (Ed.). Developments in meat science (Vol. 4, pp. 173-243). London: Elsevier Applied Science.

Offer, G., \& Trinick, J. (1983). On the mechanism of water-holding in meat: the swelling and shrinking of myofibrils. Meat Science, 8, 245-281.

Park, J.W. (2005). Ingredient technology for surimi and surimi seafood. In J.W. Park (Ed.), Surimi and surimi Seafood (2 ${ }^{\text {nd }}$, Ed.). (pp. 649-707) Boca Raton (FL): Taylor and Francis Group.

Peleg, M., I. Roy, O. H. Campanella, \& M. D. Normand. (1989). Mathematical characterization of the compressive stress-strain relationships of spongy baked goods. Journal of Food Science, 54,947-949.

Ramírez, J. A., García-Carreño, F. L., Morales, O. G., \& Sánchez, A. (2002). Inhibition of modori-associated proteinases by legume seed extracts in surimi production. Journal of Food Science, 67, 578-581.

Rohm, H. (1990). Consumer awareness of food texture in Austria. Journal of Texture Studies, 21,363-373.

Ruusunen, M., Simolin, M., \& Puolanne, E. (2001a). The effect of fat content and flavor enhancers on the perceived saltiness of cooked bologna-type sausages. Journal of Muscle Foods, $12,107-120$.

Ruusunen, M., Tirkkonen, M. S., \& Puolanne, E. (2001b). Saltiness of coarsely ground cooked ham with reduced salt content. Agricultural and Food Science in Finland, 10, 27-32.

Ruusunen, M., \& Puolanne, E. (2005). Reducing sodium intake from meat products. Meat Science, 70, 531-541.

Schwartz, S. J., von Elbe, J. H. \& Giusti, M. M. (2009). Colorants. In S. Damodaran, K. L. Parkin, \& O. R. Fennema, (Ed) Fennema’s Food Chemistry.( p. 537). CRC Press, Boca Raton, FL. 
Shahidi, F. (1994). Proteins from seafood processing discards. In: seafood proteins (edited by Z.E. Sikorski, B. Sun Pan \& F. Shahidi). (pp. 171-193). New York: Chapman and Hall.

Shimizu, Y., Machida, R. \& Takenami, S. (1981). Species variation in the gel-forming characteristics of fish meat paste. Bulletin of the Japanese Society of Scientific Fisheries, 47, 95.

Sikorski, Z. E. (2007). The role of proteins in food. In Z. E. Sikorski, (Ed.), Chemical and Functional Properties of Food Components. $\left(3^{\text {rd }}\right.$ ed $),($ p.136-140), CRC Press, Boca Raton, FL.

Smith, D. P., Fletcher, D. L. Buhr, R. J. \& Beyer. R. S. (1993). Pekin ducklings and broiler chicken pectoralis muscle structure and composition. Poultry Science, 72,202-208.

Smyth, A. B., O’Neill, E. O., \& Smith. D. M. (1999). Functional properties of muscle proteins in processed poultry products. In R. I. Richardson, and G. C. Mead, (Ed), Poultry Meat Science. (p. 377-396), CABI Publishing, New York, NY.

Stangierski, J., \& Kijowski, J. (2000). Optimization of conditions for myofibril preparation from mechanically recovered chicken meat. Nahrung, 44, 333-338.

Strasburg, G., Xiong, Y. L., \& Chiang, W. (2008). Physiology and chemistry of edible muscle tissues. In S. Damodaran, K. L. Parkin, \& O. R. Fennema(Eds.), Fennema's Food Chemistry (4 ${ }^{\text {th }}$ ,ed.). (p. 930-935\& 949-950). CRC Press, Boca Raton, (FL): Taylor and Francis Group.

Strom, T., \& Eggum, B.O. (1981). Nutritional value of fish viscera silage. Journal of the Science of Food Agriculture, 32, 115-20.

Suzuki, T. (1981). Fish and Krill Protein: Processing Technology, Applied Science Publishers, London.

Tabilo-Munizaga, G., \&Barbosa-Canovas, G. V. (2004). Color and textural parameters of pressurized and heat-treated surimi gels as affected by potato starch and egg white. Food Research International, 37,767-775.

Taguchi, T., Kikuchi, K., Oguni, M., Tanaka, M. \& Suzuki, K. (1978). Heat changes of myosin $\mathrm{B} \mathrm{Mg}^{2+}$ ATPase and setting of fish meat paste. Bulletin of the Japanese Society of Scientific Fisheries, 44, 1363.

Tahergorabi R, Hosseini S.V, Jaczynski J. 2011. Seafood Proteins. In: Philips G. O, Williams P.A, editors. Handbook of Food Proteins. (pp. 116-143). Woodhead Publishing Limited.

Taskaya, L., Chen, Y. C., \& Jaczynski, J. (2009a). Functional properties of proteins recovered from whole gutted silver carp (Hypophthalmichthys molitrix) by isoelectric solubilization /precipitation. LWT-Food Science and Technology, 42(6), 1082-1089. 
Taskaya, L., Chen, Y. C., Beamer, S., \& Jaczynski, J. (2009b). Texture and colour properties of proteins recovered from whole gutted silver carp (Hypophthalmichthys molitrix) using isoelectric solubilisation/precipitation. Journal of the Science of Food and Agriculture, 89(2), 349-358.

Taskaya, L., Chen, Y. C., Beamer, S., Tou, J. C., \& Jaczynski, J. (2009c). Compositional characteristics of materials recovered from whole gutted silver carp (Hypophthalmichthys molitrix) using isoelectric solubilization/precipitation. Journal of Agricultural and Food Chemistry, 57(10), 4259-4266.

Taskaya, L., Chen, Y. C., \& Jaczynski, J. (2010). Color improvement by titanium dioxide and its effect on gelation and texture of proteins recovered from whole fish using isoelectric solubilization/precipitation. LWT-Food Science and Technology, 43(3), 401-408.

Thawornchinsombut, S., \& Park, J.W. (2004). Role of pH in solubility and conformational changes of pacific whiting muscle proteins. Journal of Food Biochemistry, 28, 135-54.

Torres, J. A., Chen, Y. C., Rodrigo-Garcia, J., \& Jaczynski, J. (2007). Recovery of by-products from seafood processing streams. In F. Shahidi (Ed.), maximizing the value of marine byproducts (pp. 65-90). Boca Raton, USA: CRC Press.

Undeland, I., Ekstrand, B., \& Lingnert, H. (1998). Lipid oxidation in minced herring (Clupea harengus) during frozen storage. Effect of washing and precooking. Journal of Agricultural and Food Chemistry, 46(6), 2319-2328.

Undeland, I., Kelleher, S. D., \& Hultin, H. O. (2002). Recovery of functional proteins from herring light muscle by an acid or alkaline solubilization process. Journal of Agricultural and Food Chemistry, 50, 7371-7379.

Undeland, I., Kelleher, S.D., Hultin, H.O., McClements, J., \&Thongraung, C. (2003). Consistency and solubility changes in herring (Clupea harengus) light muscle homogenates as a function of pH. Journal of Agricultural and Food Chemistry, 51, 3992-8.

USDA. (2006). Sensory and physicochemical property relationships in food that define and predict end-use quality. http://www.reeis.usda.gov/web/crisprojectpages/402748.html Accessed June 2009.

Venugopal, V. (1997). Functionality and potential applications of thermostable water dispersions of fish meat. Trends in Food Science and Technology, 8 (8):271-6.

Venugopal, V., \& Shahidi, F. (1998). Traditional methods to process underutilized fish species for human consumption. Food Reviews International, 14(1):35-97.

Vodovotz, Y., Baik, M., Vittadini, E., \& Chinachoti. P. (2001). Instrumental techniques used in bread staling analysis in Bread Staling. P. Chinachoti, and Y. Vodovotz, eds. CRC Press, Boca Raton, FL. 
Weber, P., \& Raederstorff, D. (2000).Triglyceride-lowering effect of omega-3 LC polyunsaturated fatty acids. A review, Nutrition, Metabolism \& Cardiovascular Diseases, 10, 2837.

Whelton, P.K. et al. (1997). Effects of oral potassium on blood pressure. Meta-analysis of randomized controlled clinical trials. Journal of the American Medical Association, 277, 16241632. 


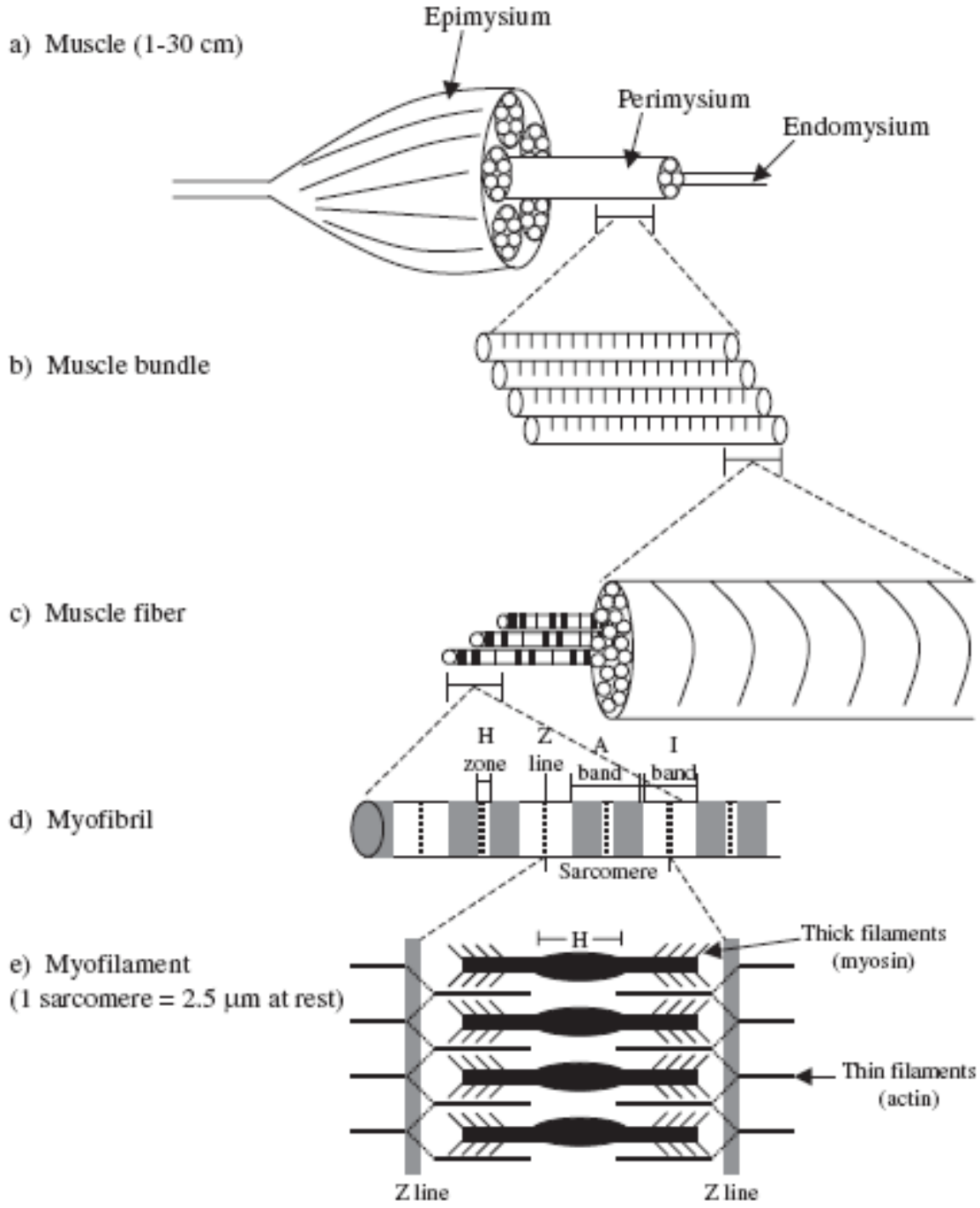

Figure 1. Schematic diagram of birds and mammals muscle structure, starting from a cross section of a whole muscle (a), including the layers of connective tissue, the muscle bundle (b), fibre (c), myofibril (d) and myofilaments (e). Reprinted from poultry products processing: an industry guide. Ebook by Shai Barbut. Copyright 2001 by Taylor \& Francis Group LLC - books. 


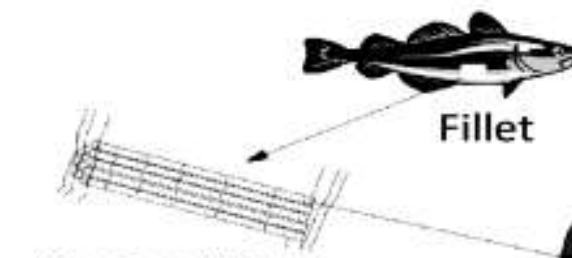

Myotome $1-2 \mathrm{~cm}$ across, visible flakes in cooked fish

Muscle fiber
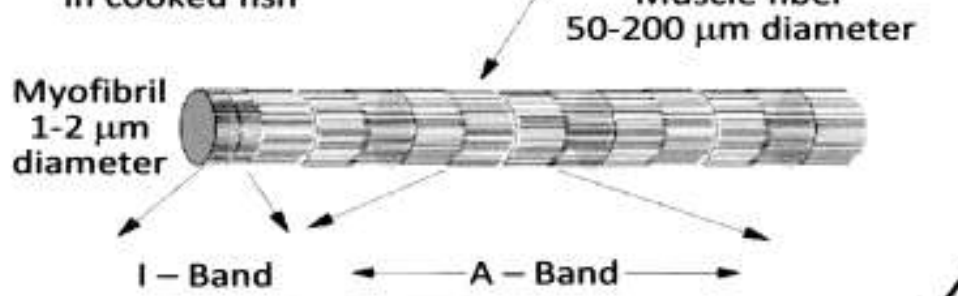

Thick filament
Myosin

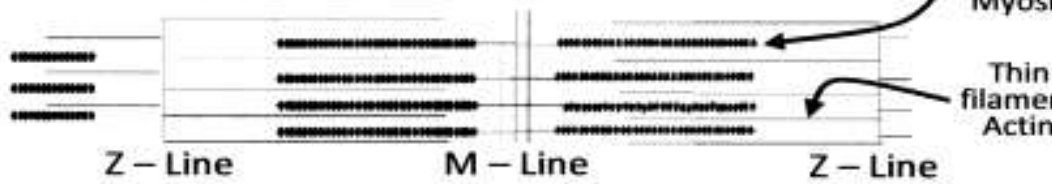

Z-Line

M-Line

Thin

Actin

Myosin molecule

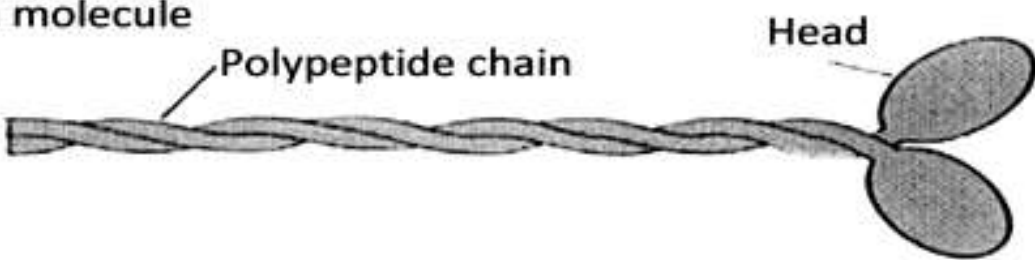

Myosin filament

Myosin heads

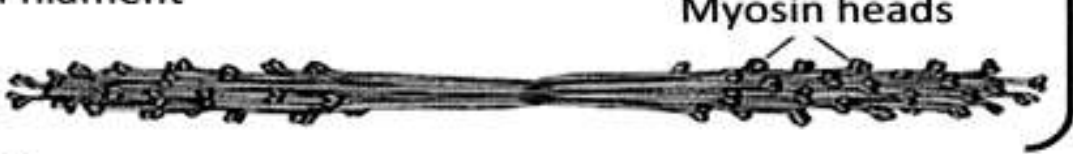

Actin filament

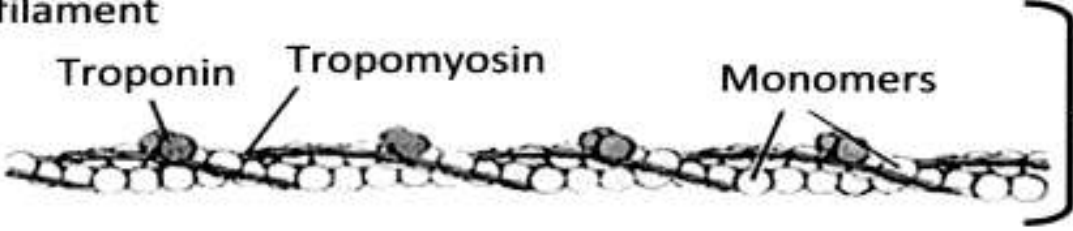

Figure 2. Structure of fish muscle tissue (Adapted from Tahergorabi et al., 2011). 


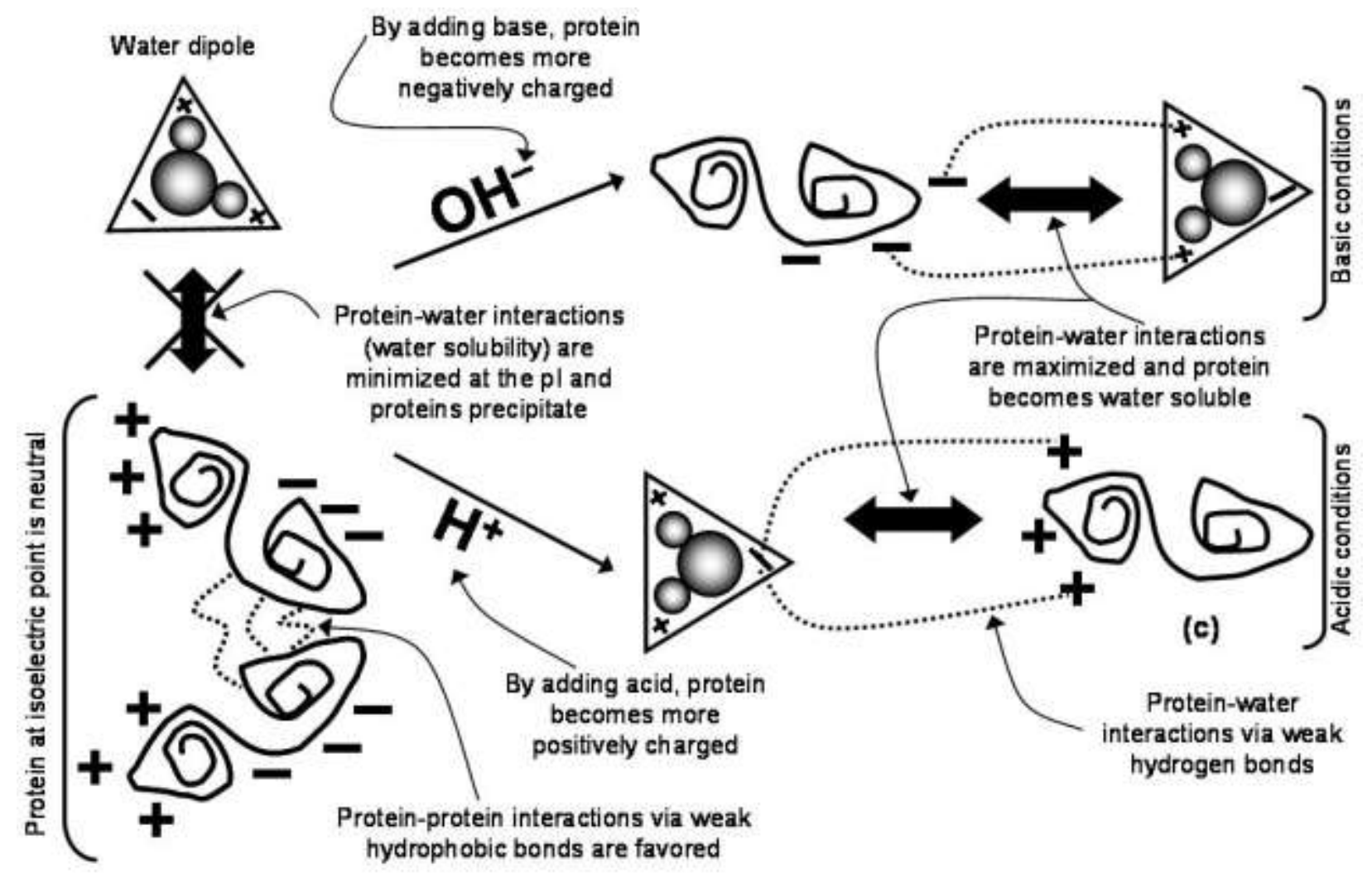

(a)

(b)

Figure 3. A protein at its isoelectric point (pI) has a zero net electrostatic charge (Adapted from Tahergorabi et al., 2011). (a) At its pI, protein-water interactions are at the minimum, while protein-protein interactions via weak hydrophobic bonds are at the maximum, causing protein precipitation (i.e., lowest water solubility). (b) Protein-water interactions prevail under acidic or basic conditions when the $\mathrm{pH}$ of protein solution is adjusted away from the pI, resulting in protein water solubility. 


\section{CHAPTER 1}

Effect of isoelectric solubilization/precipitation and titanium dioxide on whitening and texture of proteins recovered from dark chickenmeat processing by-products

Tahergorabi R, Beamer S, Matak K, Jaczynski, J. (2011). LWT - Food Science and Technology, 44(4):896-903 


\section{Abstract}

Processing of chicken generates by-products containing muscle proteins attached to bones and skin that, if recovered, could be a functional ingredient in restructured food products. However, color of restructured products made of proteins recovered from chicken processing byproducts is poor. The by-products contain bones, skin, fat, etc. that affect color of restructured products. Therefore, color properties need to be improved. The objectives of this study were to determine effects of isoelectric solubilization/precipitation (ISP) and $\mathrm{TiO}_{2}$ on instrumental color and texture properties of heat-set gels made of proteins recovered from dark chicken-meat processing by-products as compared to gels made of chicken breast meat. Skin-on bone-in chicken drumsticks were used as a model dark chicken-meat processing by-products. $\mathrm{TiO}_{2}$ at 0 $1 \mathrm{~g} / 100 \mathrm{~g}$ and canola oil at $10 \mathrm{~g} / 100 \mathrm{~g}$ were added to the ISP-recovered proteins followed by cooking. Due to higher $(\mathrm{P}<0.05)$ yellowness $\left(\mathrm{b}^{*}\right)$ and lower $(\mathrm{P}<0.05)$ lightness $\left(\mathrm{L}^{*}\right)$, the whiteness of drumstick gels without $\mathrm{TiO}_{2}$ was lower $(\mathrm{P}<0.05)$ than breast gels. $\mathrm{TiO}_{2}$ at $1 \mathrm{~g} / 100 \mathrm{~g}$ with canola oil resulted in slightly better $(\mathrm{P}<0.05)$ whiteness of drumstick gels than breast gels. $\mathrm{TiO}_{2}$ did not deteriorate gel texture, which was generally comparable to breast gels. This research indicates that ISP allows recovery of proteins from skin-on bone-in dark chicken-meat processing by-products without removal of bones, skin, and fat prior to processing. Addition of $\mathrm{TiO}_{2}$ to proteins recovered from these by-products allows development of heat-set gels with color and texture comparable to chicken breast gels. Although this study shows the potential for a novel, marketable food product, sensory tests are recommended. 
Key Words: chicken muscle proteins; protein recovery; isoelectric solubilization/precipitation; texture and color properties; titanium dioxide; food product development

\section{Introduction}

Chicken meat is a competitive source of animal proteins compared to meat from other farm animals. In addition, chicken meat generally has less total fat, saturated fat, and cholesterol than beef and pork (USDA, 2006). This is why the consumption of poultry meat has been increasing since 1940s and starting in 2000 the per capita consumption of chicken meat in the United States has become comparable to beef and greater than pork (USDA, 2006). According to the FAO, the world production of chicken meat in 1996 was 46 million tons (MT) which increased to $76 \mathrm{MT}$ in 2007. The U.S. production of chicken meat for the respective years was 11.5 and $16 \mathrm{MT}$. The world per capita consumption of poultry protein increased from $1 \mathrm{~g} /$ day in 1961 to $3 \mathrm{~g} /$ day in 1995 and $4 \mathrm{~g} /$ day in 2003 (FAO, 2009). These statistics clearly indicate the increasing popularity of chicken meat among consumers and its global importance in fulfilling human nutritional needs for protein.

Light chicken muscle (breast) and dark muscle (legs) are processed into light and dark chicken meat, respectively. Dark chicken meat has darker color as well as higher fat and cholesterol content than light chicken meat. Significant quantities of chicken thigh and drumstick meat are processed into various value-added products. The value-added food products derived from chicken meat have shown a steady growth in the U.S. and for example more than 90\% of all broilers are processed and sold as value-added products (Thornton \& O'keefe, 2002). However, the increased production of value-added products inevitably generates a large quantity 
of chicken-meat processing by-products that contain residual meat left on bones, skin, etc. (Dawson, Sheldon \& Ball, 1988). Mechanical deboning has been investigated and is commercially used to recover the residual meat from chicken-meat processing by-products (Yang \& Froning, 1992; Smyth \& O’Neill, 1997). However, mechanical deboning does not reduce myoglobin or total fat and cholesterol in the meat recovered from dark chicken-meat processing by-products. Therefore, mechanical deboning results in a typical dark color and high fat content of the recovered meat, which has been attributed to low sensory quality when compared to the products developed from light chicken meat (Perlo, Bonato, Teira, Fabres \& Kueider, 2006; Froning, 1976). It is desirable to devise a processing strategy allowing recovery of functional and nutritious muscle proteins with low fat content from low-value dark chickenmeat processing by-products for subsequent inclusion in value-added food products similar to light chicken-meat counterparts.

Unlike mechanical meat recovery such as deboning of chicken meat processing byproducts, the isoelectric solubilization/precipitation (ISP) allows selective, $\mathrm{pH}$-induced water solubility of meat proteins with concurrent separation of lipids and removal of materials not intended for human consumption such as bones, skin, etc. During ISP processing, the meat proteins are first solubilized in water at acidic or basic $\mathrm{pH}$ followed by centrifugation to separate neutral and membrane lipids by flotation and sedimentation, respectively. Bones, skin, and stroma proteins (connective tissue) are also removed in the sediment. The water-soluble meat proteins are then precipitated by adjusting the $\mathrm{pH}$ to 5.5 , which is the isoelectric point (pI) of meat proteins. The isoelectrically precipitated proteins are de-watered using centrifugation followed by their recovery. 
The role of $\mathrm{pH}$ in water solubility of muscle proteins has been described (Meinke, Rahman, \& Mattil, 1972; Meinke \& Mattil, 1973). The ISP processing of fish fillets with concurrent separation of lipids was proposed by Hultin \& Kelleher $(1999,2000)$. Muscle proteins from fish have thus far been recovered at the laboratory-scale ISP using a batch mode (Undeland, Kelleher, \& Hultin, 2002; Choi \& Park, 2002; Kristinsson \& Hultin, 2003; Kim, Park, \& Choi, 2003) and pilot plant-scale (Mireles DeWitt, Nabors, \& Kleinholz, 2007). The ISP processing has been applied to beef and fish processing by-products (Mireles DeWitt, Gomez, James, 2002; Chen \& Jaczynski, 2007a; 2007b). A bio-reactor system working in a continuous mode instead of batch has been proposed for the recovery of functional proteins and lipids from food processing by-products using ISP principles (Torres, Chen, Rodrigo-Garcia, \& Jaczynski, 2007; Jaczynski, 2010). The ISP processing allows high recovery yields for proteins while significantly reducing their fat content (Chen \& Jaczynski, 2007b; Taskaya, Chen, Beamer, \& Jaczynski, 2009b). Recovered proteins retain functional properties and nutritional value (Nosloe \& Undeland, 2009; Chen, Tou, \& Jaczynski, 2007; 2009; Gigliotti, Jaczynski, \& Tou, 2008; Taskaya et al., 2009a; 2009c). Due to extreme pH shifts during ISP, this technology results in mild, non-thermal pasteurization (Lansdowne, Beamer, Jaczynski, \& Matak, 2009a; 2009b). Therefore, ISP offers several advantages over mechanical deboning and may be a useful technology to recover functional and nutritious proteins from low-value dark chicken-meat processing by-products for subsequent application in value-added food products.

Although ISP allows efficient recovery of functional and nutritious proteins from food processing by-products; the heat-set gels developed from these proteins have poor color properties due to various pigments that are extracted and retained with the recovered proteins (Taskaya et al., 2009b). Titanium dioxide $\left(\mathrm{TiO}_{2}\right)$ is a whitening agent commonly used in the 
food and cosmetic industries. Therefore, $\mathrm{TiO}_{2}$ can be used in the development of value-added food products from the recovered proteins to obtain desired whiteness properties without affecting gelation and texture properties (Taskaya et al., 2009b). It is hypothesized that ISP of dark chicken-meat processing by-products will result in the recovery of functional proteins for a subsequent inclusion in restructured food products. Furthermore, addition of $\mathrm{TiO}_{2}$ to the recovered proteins will result in the color and texture similar to products developed from light chicken meat.

The overall objective of this study was to recover muscle proteins by ISP from model dark chicken-meat processing by-products (skin-on bone-in drumsticks) for the development of heat-set gels with color and texture similar to chicken breast meat gels. Specific objectives of this study were to determine: (1) feasibility of ISP to recover proteins from skin-on bone-in drumsticks; (2) effect of $\mathrm{TiO}_{2}$ on color and texture properties of gels made from recovered proteins as compared to gels made from chicken breast meat; (3) effect of ISP on color and texture of chicken protein gels.

\section{Materials and methods}

Sample preparation and protein recovery

Chicken drumsticks (skin-on bone-in), boneless skinless chicken drumstick meat, and boneless skinless chicken breast were purchased from a local chain grocery store. All of the meat was fresh, refrigerated, and of the same brand. Chicken drumsticks (skin-on bone-in) were used as a model dark chicken-meat processing by-products; while boneless skinless chicken drumstick meat and boneless skinless chicken breast meat were used as controls. Instrumental 
gel quality (color and texture properties, please see below) of proteins recovered by isoelectric solubilization/precipitation (ISP) from chicken drumsticks (skin-on bone-in) was compared to gels made from boneless skinless chicken drumstick meat and boneless skinless chicken breast meat.

A processing flowchart for the recovery of muscle proteins from the above chicken samples and subsequent development of chicken gels is shown in Fig. 1. Experimental treatments and treatment codes are presented in Table 1. Fresh, refrigerated chicken drumsticks (skin-on bone-in) or boneless skinless chicken breast meat were ground (meat grinder model 812 with $2.3 \mathrm{~mm}$ grinding plates, Biro, Marblehead, $\mathrm{OH}$ ) followed by homogenization with deionized water $\left(\mathrm{dd}_{2} \mathrm{O}\right)$ at 1:6 ratio (ground chicken : water, w : v) using a laboratory homogenizer (PowerGen 700, Fisher Scientific, Fairlawn, NJ) set at speed five for five minutes. Gels were also made from boneless skinless chicken drumstick meat and boneless skinless chicken breast meat without ISP (Table 1 and Fig. 1). Processing temperature was carefully controlled at either $32-34^{\circ} \mathrm{C}$ or $4^{\circ} \mathrm{C}$ during ISP (Table 1). Different temperatures were used to determine its effect on the efficiency of lipid separation from the recovered protein. The homogenization/mixing was continued with the PowerGen homogenizer set at speed three during subsequent $\mathrm{pH}$ adjustment steps. The total ISP processing time did not exceed $60 \mathrm{~min}$.

A $6 \mathrm{~L}$ aliquote of the homogenate was transferred to a beaker and the $\mathrm{pH}$ was adjusted to $11.50 \pm 0.05$ with 5 and $0.5 \mathrm{~mol} \mathrm{~L}^{-1} \mathrm{NaOH}$ (Chen et al., 2007; Chen \& Jaczynski, 2007a; 2007b; Taskaya et al., 2009a). The 5 and $0.5 \mathrm{~mol} \mathrm{~L}^{-1}$ reagents were used for crude and fine $\mathrm{pH}$ adjustments, respectively, during both protein solubilization and subsequent precipitation $(\mathrm{pH}=$ 5.5) (see below). The $\mathrm{pH} 11.50 \pm 0.05$ was held for $10 \mathrm{~min}$ followed by centrifugation at $10,000 \mathrm{x}$ $g$ and $32-34^{\circ} \mathrm{C}$ or $4^{\circ} \mathrm{C}$ for 10 min using a laboratory batch centrifuge (Sorvall Evolution RC 
Refrigerated Superspeed centrifuge equipped with Sorvall Fiber Lite rotor SLC-6000, Sorvall Centrifuges, Asheville, NC). The centrifugation resulted in three layers: top - chicken fat, middle - chicken muscle protein solution, and bottom - insolubles (bones, skin, insoluble proteins, membrane lipids, etc.).

The $\mathrm{pH}$ of the chicken muscle protein solution collected was adjusted to $5.50 \pm 0.05$ by 5 and $0.5 \mathrm{~mol} \mathrm{~L}^{-1} \mathrm{HCl}$ to isoelectrically precipitate chicken proteins. The $\mathrm{pH} 5.50 \pm 0.05$ was held for $10 \mathrm{~min}$. The solution with precipitated proteins was de-watered by centrifugation as above. The centrifugation resulted in two layers: top - process water, and bottom - precipitated and dewatered chicken muscle proteins. The precipitated and de-watered proteins were collected and used in the development of heat-set chicken gels.

\section{Development of heat-set chicken gels}

Chicken pastes were made using the procedure described by Jaczynski and Park (2004). The recovered proteins were stored in a refrigerator $\left(2^{\circ} \mathrm{C}\right)$ overnight and used within a day to formulate protein pastes for heat-set gels. The heat-set gels were also made from boneless skinless chicken drumstick meat or boneless skinless chicken breast meat (Table 1 and Fig. 1). The $\mathrm{pH}$ of precipitated and de-watered proteins or boneless skinless chicken drumstick meat or boneless skinless chicken breast meat was separately adjusted to $7.20 \pm 0.05$ with 0.5 mol L-1 $\mathrm{NaOH}$ in a temperature-controlled food processor (Sunbeam Mixmaster model 2350, Sunbeam Products Inc., Boca Raton, FL) followed by chopping at low speed for 1 min (Carvajal et al., 2005). A paste was obtained by adding salt ( $2 \mathrm{~g} / 100 \mathrm{~g})$ and chopping at low speed for $0.5 \mathrm{~min}$. Functional additives were added to the paste at the following final concentrations: $3 \mathrm{~g} / 100 \mathrm{~g}$ potato starch (PS) (Penbind 1000 modified potato startch, Penford Food Ingredients Corp., 
Centennial, CO) and $0.3 \mathrm{~g} / 100 \mathrm{~g}$ polyphosphate (PP) (Kena FP-28, Innophos, Cranbury, NJ). The functional additives were in a dry powder form. The above levels of functional additives were found in previous studies as optimal for texture development of muscle proteins recovered from food animal processing by-products using ISP (Chen \& Jaczynski, 2007a; 2007b; Taskaya et al., 2009a; 2009b; 2009c). In the present study, preliminary experiments (data not shown) were conducted to confirm these levels of functional additives as optimum for the recovered chicken proteins. Titanium dioxide $\left(\mathrm{TiO}_{2}\right)$ [Titanium (IV) oxide, Sigma-Aldrich, Inc., St. Louis, $\mathrm{MO}]$ was added to the paste at the following final concentrations: 0 (control), 0.1, 0.2, 0.3, 0.4, 0.5 , and $1.0 \mathrm{~g} / 100 \mathrm{~g}$. $\mathrm{TiO}_{2}$ was added to the paste together with the functional additives. Final moisture content was adjusted to $78 \mathrm{~g} / 100 \mathrm{~g}$ by adding ice to the paste, followed by chopping at low speed for 1 min. In treatment 12 (Table 1) canola oil purchased from a local grocery story was added at $10 \mathrm{~g} / 100 \mathrm{~g}$ to the paste. When oil is added to comminuted protein-based pastes, it results in light scattering, and therefore, improves whiteness of cooked gels. The oil replaced added ice at 1:1 (w:w) ratio (Park, 2005). Additional chopping was performed at high speed under vacuum (50 kPa) for the last $3 \mathrm{~min}$. During chopping, the paste temperature was controlled between $1-4^{\circ} \mathrm{C}$. Taskaya et al. (2009b) reported that addition of $\mathrm{TiO}_{2}$ to a protein paste resulted in poor gel quality due to the $\mathrm{pH}$ lowering effect of $\mathrm{TiO}_{2}$. Therefore, the final $\mathrm{pH}$ of the pastes in the present study was adjusted to $7.20 \pm 0.05$. Chicken pastes were prepared in 1 $\mathrm{kg}$ batches. Pastes prepared in this manner were used to develop gels for evaluation of color $\left(\mathrm{L}^{*} \mathrm{a}^{*} \mathrm{~b}\right)$ and texture properties (Kramer shear test and texture profile analysis).

Following formulation, chicken paste was stuffed into stainless steel tubes (length $=17.5$ $\mathrm{cm}$, internal diameter $=1.9 \mathrm{~cm}$ ) with screw end caps for determination of color and texture properties with tristimulus color values $\left(\mathrm{L}^{*} \mathrm{a}^{*} \mathrm{~b}\right)$, Kramer shear test, and texture profile analysis 
(TPA). The tubes were heated in a water bath set at $90^{\circ} \mathrm{C}$ for $15 \mathrm{~min}$. Following heating, tubes were chilled in ice slush and the chicken gel samples were stored at $4^{\circ} \mathrm{C}$ for $24 \mathrm{~h}$ before evaluation of color and texture.

\section{Color properties of heat-set chicken gels}

The chicken gel samples were equilibrated to room temperature for $2 \mathrm{~h}$ prior to the color measurement. The color properties of heat-set chicken gels were determined using a Minolta Chroma Meter CR-300 colorimeter (Minolta Camera Co. Ltd., Osaka, Japan). At least eight cylindrical gels $($ height $=2.54 \mathrm{~cm}$, diameter $=1.90 \mathrm{~cm}$ ) per treatment were used for color measurements. The values for the CIE (Commission Internationale d'Eclairage of France) color system using $\mathrm{L}^{*} \mathrm{a} * \mathrm{~b} *$ tristimulus color values were determined. Whiteness of gels was calculated by the following equation (Kristinsson et al., 2005; National Fisheries Institute, 1991):

$$
\text { Whiteness }=100-\left[\left(100-\mathrm{L}^{*}\right)^{2}+a^{* 2}+b^{*}\right]^{1 / 2}
$$

\section{Texture properties of heat-set chicken gels}

Two different methods were employed to determine texture: Kramer shear test and texture profile analysis (TPA). Although these texture measurements are commonly employed for determination of textural properties, each method provides slightly different information (Kim et al., 2005). The most comprehensive understanding of textural properties is provided by a combination of these methods. Therefore, these two different tests were employed in the present study. 
Chicken gel samples were equilibrated to room temperature for $2 \mathrm{~h}$ prior to the texture measurement. At least eight cylindrical gels (height $=8.0 \mathrm{~cm}$, diameter $=1.9 \mathrm{~cm}$ ) per treatment were subjected to Kramer shear test using a texture analyzer (Model TA-HDi, Texture Technologies Corp., Scarsdale, NY) with a Kramer cell attachment (Taskaya et al., 2009c; Kassis et al., 2009). The Kramer shear cell consisted of five 3.0-mm thick and 70-mm wide shear blades passing through a cell having a corresponding number of slots. Individual gel samples were weighed and placed under the blades in the Kramer cell. Shear force was measured at a $127 \mathrm{~mm} / \mathrm{min}$ crosshead speed and expressed as maximum peak force $(\mathrm{N}$ peak force/g of gel sample).

Texture profile analysis (TPA) of the gels was performed according to Cheret et al. (2005). At least eight cylindrical gels (height $=2.54 \mathrm{~cm}$, diameter $=1.90 \mathrm{~cm}$ ) per treatment were used for the TPA measurement. Gel samples were subjected to two-cycle compression at 50\% compression using the texture analyzer with a 70-mm TPA compression plate attachment moving at a speed of $127 \mathrm{~mm} / \mathrm{min}$. From the resulting force-time curves, hardness, springiness, cohesiveness, gumminess, and chewiness were determined.

\section{Determination of total fat in heat-set chicken gels}

Total fat content was determined according to the Soxhlet extraction method (AOAC, 1995) and expressed as $\mathrm{g} / 100 \mathrm{~g}$ (dry weight basis). To determine total fat content on a dry weight basis, chicken gel samples were analyzed for moisture content. For determination of moisture content, $2 \mathrm{~g}$ of sample was placed on an aluminum dish (Fisher Scientific Co., 
Fairlawn, NJ), spread evenly across the dish and oven-dried $\left(105^{\circ} \mathrm{C}\right.$ for $\left.24 \mathrm{~h}\right)(\mathrm{AOAC}, 1995)$.

The total fat content is reported as a mean value of at least three replicates.

\section{Statistics}

The experiments were triplicated $(n=3)$. In each triplicate at least eight measurements were performed for determination of color (i.e., $\mathrm{L}^{*} \mathrm{a}^{*} \mathrm{~b}^{*}$ ) and texture properties (i.e., Kramer shear test and TPA); and at least three measurements were performed to determine total fat content. Data were subjected to one-way analysis of variance (ANOVA). A significant difference was determined at 0.05 probability level and differences between treatments were tested using the Fisher's Least Significant Difference (LSD) test (Freud \& Wilson, 1997). All statistical analyses of data were performed using SAS (2002). The data are reported as mean values \pm standard deviation $(\mathrm{SD})$.

\section{Results and Discussion}

Proper color and texture are critical quality attributes of restructured food products. However, when food processing by-products containing bones, skin, etc. are processed in order to recover functional proteins as a base ingredient for restructured products, the recovered proteins often have unacceptably poor color properties (Taskaya et al., 2009b; 2010). There have been attempts to optimize processing conditions to produce surimi-like protein isolates from mechanically deboned poultry meat (Hernandez, Baker \& Hotchkiss, 1986; Wimmer, Sebranek \& Mcketch, 1993; Kijowski \& Richardson, 1996). Surimi processing is a technology that allows recovery and concentration of muscle proteins (mainly myofibrillar). Surimi 
processing is commercially used for headed-and-gutted fish (i.e., clean muscle tissue). Among other limitations, surimi processing cannot be applied to food processing by-products and offers relatively low recovery yields when compared to ISP (Gehring, Gigliotti, Moritz, Tou, \& Jaczynski, 2010). This is why surimi technology cannot be directly applied to dark chicken-meat processing by-products unless meat if first recovered by mechanical deboning. Proteins recovered from mechanically deboned chicken meat using surimi technology often have unacceptable color and the heat-set gels made from these proteins have poor texture (i.e., gelation), color properties, and also undesirable smell (Stangierski \& Kijowski, 2000). In contrast, proteins recovered from food processing by-products containing bones, skin, etc. with ISP have been shown to retain gel-forming ability; and therefore, gels made from these proteins have good texture and also color properties if $\mathrm{TiO}_{2}$ is added (Taskaya et al., 2010).

The ISP at basic rather than acidic $\mathrm{pH}$ allows recovery of proteins with better functionalities; and therefore, better thermal gelation and consequently, texture as well as color (i.e., whiteness) properties (Kristinsson \& Hultin, 2003; Kristinsson \& Liang, 2006; Nosloe \& Undeland, 2009). In addition, ISP at basic pH yields proteins with higher nutritional quality as assessed by a greater amount of essential amino acids (EAA) compared to ISP at acidic $\mathrm{pH}$ (Chen et al., 2007; 2009; Gigliotti et al., 2008). Lipids are also removed to a greater degree from the recovered proteins when ISP is conducted at basic pH (Chen \& Jaczynski, 2007a; 2007b; Taskaya et al., 2009b). For these reasons ISP at pH 11.5 instead of acidic $\mathrm{pH}$ or surimi technology was applied in the present study to recover proteins from model dark chicken-meat processing by-products (skin-on bone-in drumsticks). $\mathrm{TiO}_{2}$ is often added to various food products to improve whiteness (Meacock, Taylor, Knowles, \& Himonides, 1997; Taskaya et al., 2010). Benjakul et al. (2004) demonstrated that $\mathrm{TiO}_{2}$ improves whiteness of surimi gels without 
affecting heat-induced protein gelation. This is why in the present study various levels of $\mathrm{TiO}_{2}$ were added to the recovered proteins in order to match the whiteness of gels made from the recovered proteins with gels made from boneless skinless chicken breast. Canola oil was also added (treatment 12 only, Table 1) to aid $\mathrm{TiO}_{2}$ in whiteness improvement. Vegetable oils are commonly used in surimi-based products as a color and texture enhancer. It has been shown that oil addition results in proportional increase of lightness $\left(\mathrm{L}^{*}\right)$ due to light scattering; and therefore, improved whiteness of surimi gels (Park, 2005). The ISP processing in the present study was conducted at elevated temperature $\left(32-34^{\circ} \mathrm{C}\right)$ and refrigeration $\left(4^{\circ} \mathrm{C}\right)$. Higher temperature typically results in less viscous fat; and therefore, increased fat separation by centrifugation, which in turn, would facilitate fat reduction including cholesterol in the recovered proteins. Skin-on bone-in drumsticks (i.e., the starting material for ISP in the present study) typically contain more fat than boneless skinless chicken breast meat. Therefore, ISP at elevated temperature could yield proteins with fat content comparable to boneless skinless chicken breast meat.

In the present study, some dark pigment components were likely extracted from skin-on bone-in chicken drumsticks and retained with the recovered proteins. When $\mathrm{TiO}_{2}$ was not added to proteins recovered from drumsticks, the gel whiteness was very poor (59.4, treatment 4 in Fig. 2) and much lower $(\mathrm{P}<0.05)$ than for the gels made of boneless skinless chicken drumstick $(71.0$, treatment 3 in Fig. 2) or boneless skinless chicken breast (76.0 and 77.4, treatments 1 and 2 in Fig. 2). However, $\mathrm{TiO}_{2}$ improved gel whiteness $(\mathrm{P}<0.05)$ (63.9-80.6, treatments 5-12 in Fig. 2). Taskaya et al. (2010) reported similar whiteness values for gels with added $\mathrm{TiO}_{2}$ made of proteins recovered by ISP from whole gutted fish (containing bones, skin, etc.). The lower whiteness of gels made from ISP-recovered proteins without $\mathrm{TiO}_{2}$ in the present study was 
generally due to the higher yellowness $\left(b^{*}\right)$ and lower lightness $\left(\mathrm{L}^{*}\right)$ (Table 3$)$. The addition of $\mathrm{TiO}_{2}$ at $1 \mathrm{~g} / 100 \mathrm{~g}$ and canola oil at $10 \mathrm{~g} / 100 \mathrm{~g}$ (treatment 12 , Table 1) resulted in the highest $(\mathrm{P}<0.05)$ whiteness $(80.6$, treatment 12 in Fig. 2$)$ due to increased $(\mathrm{P}<0.05) \mathrm{L}^{*}$ and generally lower $\mathrm{b}^{*}$ (Table 3). Gel whiteness for treatment $12(80.6)$ was slightly higher $(\mathrm{P}<0.05)$ than for the gels made of boneless skinless chicken breast (76.0-77.4). Therefore, it is possible to develop restructured food products from skin-on bone-in drumsticks (i.e., dark-meat chicken processing by-products) by using ISP and $\mathrm{TiO}_{2}$ that resemble whiteness of restructured light chicken-meat products. It appears that finely dispersed white particles of $\mathrm{TiO}_{2}$ considerably increased $\mathrm{L}^{*}$ due to light scattering and at the same time, $\mathrm{TiO}_{2}$ masked the yellow (b*) hue of the gels which consequently resulted in increased whiteness of the drumstick gels. The elevated temperature $\left(32-34^{\circ} \mathrm{C}\right)$ during ISP resulted in less $(\mathrm{P}<0.05)$ efficient fat removal from the recovered proteins. The proteins recovered with ISP conducted at $32-34^{\circ} \mathrm{C}$ had higher $(\mathrm{P}<0.05)$ fat content compared to the proteins recovered at $4^{\circ} \mathrm{C}$ (Table 2). Chicken fat has a yellow color. The proteins recovered with ISP at lower temperature (i.e., $\left.4^{\circ} \mathrm{C}\right)$ had higher $(\mathrm{P}<0.05)$ whiteness (treatment 8 vs. 9 and 11 vs. 12 in Fig. 2) probably due to lower chicken fat content.

Hernandez et al. (1986) showed that surimi processing of mechanically deboned turkey neck meat improves whiteness of cooked turkey surimi gels due to increased $\mathrm{L}^{*}$ and reduced $\mathrm{a}^{*}$ values. Surimi processing reduces fat content and other water-soluble impurities such as myoglobin. Hernandez et al. (1986) reported $\mathrm{L}^{*} 60.6$ and $\mathrm{a}^{*}$ 3.9. The $\mathrm{a}^{*}$ was comparable to the $a^{*}$ in the present study, but $L^{*}$ was considerably lower in the Hernandez et al.'s (1986) study. In the present study, ISP and $\mathrm{TiO}_{2}$ were used which likely account for the differences. Kelleher and Hultin (2000) used ISP to recover proteins from chicken thigh and leg muscle. However, fat was trimmed and bones as well as skin were removed prior to ISP. $\mathrm{TiO}_{2}$ was not used either. The 
gels made from the ISP-recovered proteins had $\mathrm{L}^{*} 69.0, \mathrm{a}^{*}-0.2$, and $\mathrm{b}^{*} 12.8$. The $\mathrm{L}^{*}$ in the present study for treatment $5\left(\mathrm{~L}^{*} 70.5\right)$ is very similar (Table 3$)$. However, subsequent additions of $\mathrm{TiO}_{2}$ resulted in higher $\mathrm{L}^{*}$ in the present study. By comparing values obtained with surimi processing (Hernandez et al., 1986 - L* 60.6 and a* 3.9) vs. ISP (Kelleher and Hultin, 2000 $\left.\mathrm{L}^{*} 69.0, \mathrm{a}^{*}-0.2\right)$, it is clear that ISP processing results in better color properties of cooked gels. The $\mathrm{a}^{*}$ and $\mathrm{b}^{*}$ reported by Kelleher and Hultin (2000) are lower than in the present study probably because their starting material for ISP did not have bones and skin as well as the fat was trimmed. Based on the $\mathrm{L}^{*} \mathrm{a} * \mathrm{~b} *$ values reported by Kelleher and Hultin (2000) and using the same equation as in the present study, the whiteness in Kelleher and Hultin's (2000) study is 66.5. This value is similar to treatment $6\left(\mathrm{~L}^{*} 66.9\right)$ in the present study which used $0.2 \mathrm{~g} / 100 \mathrm{~g}$ $\mathrm{TiO}_{2}$, but considerably lower than treatments 7-12 (L*67.7-80.6) and gels made from boneless skinless chicken breast ( $\left.\mathrm{L}^{*} 76.0-77.4\right)$. This further confirms that $\mathrm{TiO}_{2}$ and ISP allow development of restructured chicken-meat products with comparable color properties to light chicken-meat restructured products without removal of bones, skin, or fat from the starting material prior to ISP processing.

Many studies have indicated differences in protein functional properties of light and dark poultry meat. In restructured chicken products, light meat has better water binding properties than the dark meat (Froning \& Norman, 1966; Maesso et al., 1970). Protein extractability is also greater for light meat (Richardson \& Jones, 1987). Therefore, the differences in protein functionalities of light and dark chicken muscle may translate into differences of textural properties in the restructured chicken products. Mechanically deboned poultry meat may contain some bone residue, which may interfere with proper texture development of the restructured chicken products. Stroma proteins (connective tissue) impair texture by interfering with the 
formation of heat-induced protein gel network (Yang \& Froning, 1992). Therefore, for proper textural properties of the restructured chicken products, the proteins should have functionalities uncompromised due to the recovery technique, while stroma proteins and bone residue should be reduced as much as possible. Since stroma proteins and bones are water insoluble, surimi processing cannot remove these impurities from mechanically deboned poultry meat. However, Liang and Hultin (2003) showed that ISP removes stroma proteins and bone residue from mechanically deboned turkey meat in the sediment during the first centrifugation step (Figure 1). It has also been demonstrated that the ISP-recovered proteins retain functionalities that are important in gelation and texture (Kristinsson \& Hultin, 2003; Kristinsson \& Liang, 2006). Therefore, in terms of the final texture, ISP seems a better strategy to recover proteins from skinon bone-in drumsticks (i.e., dark-meat chicken processing by-products) than surimi processing. When boneless skinless chicken breast was processed with ISP (treatment 2), the resultant gels showed the highest $(\mathrm{P}<0.05)$ Kramer shear force $($ Fig. 3). When skin-on bone-in chicken drumsticks were processed with ISP (treatments 4-12), the shear force generally increased with the increasing levels of $\mathrm{TiO}_{2}$. Similar trend was confirmed for hardness using texture profile analysis (TPA) (Fig. 4). Skin-on bone-in drumstick gels without $\mathrm{TiO}_{2}$ (treatment 4) generally had the lowest textural properties (Figs. 3 and 4, Table 4). Drumstick gels with 1 $\mathrm{g} / 100 \mathrm{~g}$ of $\mathrm{TiO}_{2}$ and $10 \mathrm{~g} / 100 \mathrm{~g}$ of canola oil (treatment 12) had similar ( $\left.\mathrm{P}>0.05\right)$ hardness and generally similar shear force to gels made of boneless skinless chicken breast (Figs. 3 and 4). The TPA parameters, springiness, cohesiveness, gumminess, and chewiness are shown in Table 4. The drumstick gels with $1 \mathrm{~g} / 100 \mathrm{~g}$ of $\mathrm{TiO}_{2}$ and $10 \mathrm{~g} / 100 \mathrm{~g}$ of canola oil (treatment 12) generally had the best TPA parameters. Jin, Kim, Choi, Park, and Yang (2008) showed very similar trends for texture. However, these authors used chicken breast meat to compare ISP at 
acidic and basic $\mathrm{pH}$ with surimi processing. Jin et al. (2008) demonstrated that ISP at basic $\mathrm{pH}$ results in better texture of cooked chicken breast gels than ISP at acidic $\mathrm{pH}$ or surimi processing. The total fat content in starting material (skin-on bone-in chicken drumstick) was the highest $(\mathrm{P}<0.05)(30.4 \mathrm{~g} / 100 \mathrm{~g}$, dry weight, Table 2$)$. Fat content was reduced in the recovered proteins to 15.8 and $4.7 \mathrm{~g} / 100 \mathrm{~g}$ when ISP was conducted at $32-34$ and $4{ }^{\circ} \mathrm{C}$, respectively. Myosin, a major muscle protein has been shown to undergo partial denaturation and aggregation when subjected to ISP. In addition, myosin aggregation, the initial step in heat-induced denaturation starts in mid $30^{\circ} \mathrm{C}$ (Yongswatdigul \& Park, 2004). When ISP was conducted at 32$34^{\circ} \mathrm{C}$ proteins were probably aggregating which might have resulted in entrapment of fat. This fat entrapment might have caused less efficient fat separation during first centrifugation (Fig. 1). This is probably why proteins recovered at $32-34^{\circ} \mathrm{C}$ contained more fat than at $4^{\circ} \mathrm{C}$. The ISP processing at elevated temperatures is not recommended for chicken. The fat content in proteins recovered with ISP at $4^{\circ} \mathrm{C}$ (fat $4.7 \mathrm{~g} / 100 \mathrm{~g}$, dry weight) was slightly lower $(\mathrm{P}<0.05)$ than in boneless skinless chicken breast (fat $6.1 \mathrm{~g} / 100 \mathrm{~g}$, dry weight, Table 2). Kelleher and Hultin (2000) reported very similar fat content for protein isolate (fat $4.1 \mathrm{~g} / 100 \mathrm{~g}$, dry weight) recovered from boneless skinless chicken leg muscle (fat $20.4 \mathrm{~g} / 100 \mathrm{~g}$, dry weight). Liang and Hultin (2003) reported very similar fat reduction in the protein isolate (fat 3.2-4.1 g/100 g, dry weight) recovered from mechanically deboned turkey meat (fat 49.5-60.3 g/100 g, dry weight).

\section{Conclusions}

Isoelectric solubilization/precipitation (ISP) was evaluated as a means to recover proteins from model dark chicken-meat processing by-products (skin-on bone-in drumsticks) for the development of heat-set gels with color and texture similar to chicken breast meat gels. The 
proteins recovered from drumsticks using ISP at $\mathrm{pH} 11.5$ formed good quality gel and when 1 $\mathrm{g} / 100 \mathrm{~g}$ of $\mathrm{TiO}_{2}$ was added the gel whiteness was similar to $(\mathrm{P}>0.05)$ to chicken breast gels. $\mathrm{TiO}_{2}$ improved $(\mathrm{P}<0.05)$ whiteness of drumsticks gels due to increased lightness $\left(\mathrm{L}^{*}\right)$. The addition of $\mathrm{TiO}_{2}$ at $1 \mathrm{~g} / 100 \mathrm{~g}$ and canola oil at $10 \mathrm{~g} / 100 \mathrm{~g}$ resulted in the highest $(\mathrm{P}<0.05)$ whiteness without chalky or artificially white appearance. Texture properties of drumsticks gels were generally poorer than chicken breast gels. However, some treatments resulted in comparable $(\mathrm{P}>0.05)$ Kramer shear force and texture profile analysis (TPA) parameters. Furthermore, the proteins recovered by ISP at $4^{\circ} \mathrm{C}$ had the lowest $(\mathrm{P}<0.05)$ fat content that was slightly lower $(\mathrm{P}<0.05)$ than in boneless skinless chicken breast meat. Although the results of this study point towards the potential for a novel, marketable food product, sensory tests are recommended. 


\section{References}

Association of Official Analytical Chemists. (1995). Official Methods of Analysis. 16th ed., Washington, DC: Association of Official Analytical Chemists.

Benjakul, S., Visessanguan, W., \& Kwalumtharn, Y. (2004). The effect of whitening agents on the gel-forming ability and whiteness of surimi. International Journal of Food Science and Technology, 39,773-781.

Carvajal, P. A., Lanier, T. C., \& Macdonald, G. A. (2005). Stabilization of proteins in surimi. In J. W. Park, Surimi and Surimi Seafood, $2^{\text {nd }}$, ed. (p 163-225). Boca Raton (FL): Taylor and Francis Group.

Chen, Y. C., \& Jaczynski, J. (2007a). Gelation of protein recovered from Antarctic krill (Euphausia superba) by isoelectric solublization/precipitation as affected by function additives. Journal of Agricultural and Food Chemistry, 55, 1814-1822.

Chen, Y. C., \& Jaczynski, J. (2007b). Protein recovery from rainbow trout (Oncorhynchus mykiss) processing by-products via isoelectric solubilization / precipitation and its gelation properties as affected by functional additives. Journal of Agricultural and Food Chemistry, $55,9079-9088$.

Chen, Y. C., Tou J. C., \& Jaczynski, J. (2007). Amino acid, fatty acid, and mineral profiles of materials recovered from rainbow trout (Oncorhynchus mykiss) processing by-products using isoelectric solubilization / precipitation. Journal of Food Science, 72(9), C527-535.

Chen, Y. C., Tou, J. C., \& Jaczynski, J. (2009). Amino acid and mineral composition of protein and other components and their recovery yields from whole Antarctic krill (Euphausia superba) using isoelectric solubilization / precipitation. Journal of Food Science, 74(2), H31-H39.

Cheret, R., Chapleau, N., Delbarre-Ladrat, C., Verrez-Bagnis, V., \& Lamballerie, M. D. (2005). Effects of high pressure on texture and microstructure of sea bass (Dicentrarchus labrax L.) fillets. Journal of Food Science, 70, E477-483.

Choi, Y. J., \& Park, J. W. (2002). Acid-aided protein recovery from enzyme-rich Pacific whiting. Journal of Food Science, 67, 2962-2967.

Dawson, P. L., Sheldon, B. W., \& Ball, H. R. (1988).Extraction of lipid and pigment components from mechanically deboned chicken meat. Journal of Food Science, 53, 16151617.

Food and Agriculture Organization of the United Nations. (2009). The consumption of poultry meat. FAO statistical yearbook. Rome, Italy 
Freud, R. J., \& Wilson, W.J. (1997). Design of experiments (p 464). San Diego (CA): Academic Press.

Froning, G. W., \& Norman, G. (1966). Binding and water retention properties of light and dark chicken meat. Journal of Poultry Science, 45, 797-800.

Froning, G. W. (1976). Mechanically-deboned poultry meat. Food Technology, 30, 50-63.

Gehring, C. K., Gigliotti, J. C., Moritz, J. S., Tou, J. C., \& Jaczynski, J. (2011). Functional and nutritional characteristics of proteins and lipids recovered by isoelectric processing of fish by-products and low-value fish - a review. Food Chemistry, 124(2), 422-431.

Gigliotti, J. C., Jaczynski, J., \& Tou, J. C. (2008). Determination of the nutritional value, protein quality and safety of krill protein concentrate isolated using an isoelectric solubilization / precipitation technique. Food Chemistry, 111(1), 209-214.

Hernandez, A., Baker, R. C., \& Hotchkiss, J. H. (1986). Extraction of pigments from mechanically deboned turkey meat. Journal of Food Science, 51, 865-867.

Hultin, H. O. \& Kelleher, S. D. (1999). Process for isolating a protein composition from a muscle source and protein composition. U.S. Patent and Trademark Office, patent number $6,005,073$.

Hultin, H. O., \& Kelleher, S. D. (2000). High efficiency alkaline protein extraction. U.S. Patent and Trademark Office, patent number 6,136,959.

Jaczynski J. (2010). Continuous protein and lipid recovery from food animal processing byproducts. U.S. Patent and Trademark Office, patent number 7,763,717.

Jaczynski, J., \& Park, J. W. (2004). Physicochemical changes in Alaska Pollock surimi and surimi gel as affected by electron beam. Journal of Food Science, 69, 53-57.

Jin, S. K., Kim, I. S., Choi, Y. J., Park, G. B., \& Yang, H. S. (2008). Quality characteristics of chicken breast surimi as affected by water washing time and $\mathrm{pH}$ adjustment. AsianAustralasian Journal of Animal Sciences, 21(3), 449-455.

Kassis, N., Drake, S. R., Beamer, S. K., Matak, K. E., Jaczynski, J. (2009). Development of nutraceutical egg products with omega-3-rich oils. LWT-Food Science and Technology, 43(5), 777-783.

Kijowski, J., \& Richardson, R. I. (1996). The effect of cryoprotectants during freezing or freeze drying upon properties of washed mechanically recovered broiler meat. International Journal of Food Science and Technology, 31(1), 45-54.

Kim, Y. S., Park, J. W., \& Choi, Y. J. (2003). New approaches for the effective recovery of fish proteins and their physicochemical characteristics. Fisheries Science, 69(6), 1231-1239. 
Kim, B. Y., Park, J. W., \& Yoon, W. B. (2005). Rheology and texture properties of surimi gels. In J. W. Park, Surimi and Surimi Seafood, $2^{\text {nd }}$ ed. (p 491-582). Boca Raton (FL): Taylor and Francis Group.

Kelleher, S. D., \& Hultin, H. O. (2000). Functional chicken muscle protein isolates prepared using low ionic strength, acid solubilization/precipitation. In proc. Reciprocal Meat Conference; Meat Science the New Millennium. pp 76-81, American Meat Science Association, Savoy, IL.

Kristinsson, H. G., \& Hultin, H. O. (2003). Changes in conformation and subunit assembly of cod myosin at low and high $\mathrm{pH}$ and after subsequent refolding. Journal of Agricultural and Food Chemistry, 51(24), 7187-7196.

Kristinsson, H. G., \& Liang, Y. (2006). Effect of pH-shift processing and surimi processing on Atlantic croaker (Micropogonias undulates) muscle proteins. Journal of Food Science, 71, 304-312.

Kristinsson, H. G., Theodore, A. E., Demir, N., \& Ingadottir, B. (2005). A comparative study between acid- and alkali-aided processing and surimi processing for the recovery of proteins from channel catfish muscle. Journal of Food Science, 70, C298-C306.

Lansdowne, L., Beamer, S., Jaczynski, J., \& Matak, K. E. (2009a). Survival of Escherichia coli after isoelectric solubilization / precipitation of fish. Journal of Food Protection, 72(7), 1398-1403.

Lansdowne, L., Beamer, S., Jaczynski, J., \& Matak, K. E. (2009b). Survival of Listeria innocua after isoelectric solubilization and precipitation of fish protein. Journal of Food Science, 74(4), M201-205.

Liang, Y., \& Hultin, O. H. (2003). Functional protein isolates from mechanically deboned turkey by alkaline solubilization with isoelectric precipitation. Journal of Muscle Food, 14, 195-205.

Maesso, E. R., Baker, R. C., \& Vadehra, D. V. (1970). The effect of vacuum, pressure, pH and different meat types on the binding ability of poultry meat. Journal of Poultry Science, 49, 697-700.

Meacock, G., Taylor, K. D. A., Knowles, M. J., \& Himonides, A. (1997). The improved whitening of minced cod flesh using dispersed titanium dioxide. Journal of Science of Food and Agriculture, 73, 221-225.

Meinke, W. W., \& Mattil, K. F. (1973). Autolysis as a factor in the production of protein isolates from whole fish. Journal of Food Science, 38, 864-866.

Meinke, W. W., Rahman, M. A., \& Mattil, K. F. (1972). Some factors influencing the production of protein isolates from whole fish. Journal of Food Science, 37, 195-198. 
Mireles DeWitt, C. A., Gomez, G., \& James, J. M. (2002). Protein extraction from beef heart using acid solubilization. Journal of Food Science, 67, 3335-3341.

Mireles DeWitt, C. A., Nabors, R. L., \& Kleinholz, C. W. (2007). Pilot plant scale production of protein from catfish treated by acid solubilization/isoelectric precipitation. Journal of Food Science, 72, E351-E355.

National Fisheries Institute. (1991). A Manual of Standard Methods for Measuring and Specifying the Properties of Surimi. Washington (D.C.): National Fisheries Institute.

Nolsoe, H., \& Undeland, I. (2009). The acid and alkaline solubilization process for the isolation of muscle proteins: State of the art. Food Bioprocess Technology, 2, 1-27.

Park, J. W. (2005). Ingredient technology for surimi and surimi seafood. In J. W. Park, Surimi and Surimi Seafood, $2^{\text {nd }}$, ed. (p 649-707). Boca Raton (FL): Taylor and Francis Group.

Perlo, F., Bonato, P., Teira, G., Fabre, R., \& Kueider, S. (2006). Physicochemical and sensory properties of chicken nuggets with washed mechanically deboned chicken meat: Research note. Journal of Meat Science, 72, 785-788.

Richardson, R. I., \& Jones, J. M. (1987). The effect of salt concentration and pH upon waterbinding, water-holding and protein extractability of turkey meat. International Journal of Food Science and Technology, 22, 683-692.

SAS Institute (2002). SAS/STAT guide for personal computers, version 8.1. Cary (NC):SAS Institute.

Smyth, A. B., \& O’Neill, E. (1997). Heat induced gelation properties of surimi from mechanically separated chicken. Journal of Food Science, 62, 326-330.

Stangierski, J., \& Kijowski, J. (2000). Optimization of conditions for myofibril preparation from mechanically recovered chicken meat. Nahrung, 44, 333-338.

Taskaya, L., Chen, Y. C., \& Jaczynski, J. (2009a). Functional properties of proteins recovered from whole gutted silver carp (Hypophthalmichthys molitrix) by isoelectric solubilization / precipitation. LWT - Food Science and Technology, 42(6), 1082-1089.

Taskaya, L., Chen, Y. C., Beamer, S., \& Jaczynski, J. (2009b). Texture and colour properties of proteins recovered from whole gutted silver carp (Hypophthalmichthys molitrix) using isoelectric solubilisation / precipitation. Journal of the Science of Food and Agriculture, 89(2), 349-358.

Taskaya, L., Chen, Y. C., Beamer, S., Tou, J. C., \& Jaczynski, J. (2009c). Compositional characteristics of materials recovered from whole gutted silver carp (Hypophthalmichthys 
molitrix) using isoelectric solubilization/precipitation. Journal of Agricultural and Food Chemistry, 57(10), 4259-4266.

Taskaya, L., Chen, Y. C., \& Jaczynski, J. (2010). Color improvement by titanium dioxide and its effect on gelation and texture of proteins recovered from whole fish using isoelectric solubilization/precipitation. LWT - Food Science and Technology, 43(3), 401- 408.

Torres, J. A., Chen, Y. C., Rodrigo-Garcia, J., \& Jaczynski, J. (2007). Recovery of byproducts from seafood processing streams. In F. Shahidi (Ed.), Maximising the value of marine by-products (pp. 65-90). Boca Raton, USA: CRC Press.

Thornton, G., \& O'keefe, T. (2002), Value addition - the US poultry meat industry's second transformation, Poultry International, October, 10-14.

Undeland, I., Kelleher, S. D., \& Hultin, H. O. (2002). Recovery of functional proteins from herring light muscle by an acid or alkaline solubilization process. Journal of Agricultural and Food Chemistry, 50, 7371-7379.

USDA. (2006). Amber waves: The economics of food, farming, natural resources, and rural America. Accessed on March 16, 2010. http://www.ers.usda.gov/AmberWaves/April06/Findings/Chicken.htm

Wimmer, M. P., Sebranek, J. G., \& Mckeith, F. K. (1993). Washed mechanically separated pork as a surimi-like meat-product ingredient. Journal of Food Science, 58, 254-258.

Yang, T. S., \& Froning, G. W. (1992). Selected washing processes affect thermal gelation properties and microstructure of mechanically separated chicken meat. Journal of Food Science, 57, 325-329.

Yongswatdigul, J., \& Park, J. W. (2004). Effects of alkali and acid solubilization on gelation characteristics of rockfish muscle proteins. Journal of Food Science, 69, 499-505. 
Table 1. Description of experimental treatments and treatment codes. Chicken gels were formulated prior to cooking to contain 78 $\mathrm{g} / 100 \mathrm{~g}$ moisture, $3 \mathrm{~g} / 100 \mathrm{~g}$ potato starch (PS), $2 \mathrm{~g} / 100 \mathrm{~g} \mathrm{NaCl}, 0.3 \mathrm{~g} / 100 \mathrm{~g}$ polyphosphate (PP), and $\mathrm{pH}$ was adjusted to 7.2 . Source of protein, isoelectric solubilization/precipitation, concentration of $\mathrm{TiO}_{2}$, processing temperature, and oil addition were experimental variables.

\begin{tabular}{|c|c|c|c|c|c|}
\hline $\begin{array}{l}\text { Experimental } \\
\text { treatment code }\end{array}$ & Source of proteins for gels & $\begin{array}{c}\text { Isoelectric } \\
\text { solubilization/precipitation }\end{array}$ & $\begin{array}{l}\text { Concentration of } \\
\mathrm{TiO}_{2}(\mathrm{~g} / \mathbf{1 0 0} \mathrm{g})\end{array}$ & $\begin{array}{c}\text { Processing } \\
\text { temperature }\left({ }^{\circ} \mathrm{C}\right)\end{array}$ & $\begin{array}{l}\text { Oil addition } \\
(10 \mathrm{~g} / 100 \mathrm{~g})\end{array}$ \\
\hline 1 & Boneless skinless chicken breast & No & 0 & $32-34$ & No \\
\hline 2 & Boneless skinless chicken breast & Yes & 0 & $32-34$ & No \\
\hline 3 & Boneless skinless chicken drumstick & No & 0 & $32-34$ & No \\
\hline 4 & Skin-on bone-in chicken drumstick & Yes & 0 & $32-34$ & No \\
\hline 5 & Skin-on bone-in chicken drumstick & Yes & 0.1 & $32-34$ & No \\
\hline 6 & Skin-on bone-in chicken drumstick & Yes & 0.2 & $32-34$ & No \\
\hline 7 & Skin-on bone-in chicken drumstick & Yes & 0.3 & $32-34$ & No \\
\hline 8 & Skin-on bone-in chicken drumstick & Yes & 0.4 & $32-34$ & No \\
\hline 9 & Skin-on bone-in chicken drumstick & Yes & 0.4 & 4 & No \\
\hline 10 & Skin-on bone-in chicken drumstick & Yes & 0.5 & $32-34$ & No \\
\hline 11 & Skin-on bone-in chicken drumstick & Yes & 1.0 & $32-34$ & No \\
\hline 12 & Skin-on bone-in chicken drumstick & Yes & 1.0 & 4 & Yes \\
\hline
\end{tabular}


Table 2. Total fat content ${ }^{a}$.

\begin{tabular}{|c|c|c|c|c|c|}
\hline & $\begin{array}{l}\text { Skin-on bone-in } \\
\text { chicken drumstick } \\
\text { (starting material for } \\
\text { ISP) }\end{array}$ & $\begin{array}{l}\text { Boneless skinless } \\
\text { chicken drumsticks }\end{array}$ & $\begin{array}{l}\text { Chicken PI at } \\
32-34^{\circ} \mathrm{C}\end{array}$ & $\begin{array}{c}\text { Boneless skinless } \\
\text { chicken breast }\end{array}$ & $\begin{array}{c}\text { Chicken PI } \\
\text { at } 4^{\circ} \mathrm{C}\end{array}$ \\
\hline $\begin{array}{l}\text { Total fat } \\
\text { content } \\
\text { (g/100 g, } \\
\text { dry weight) }\end{array}$ & $\begin{array}{c}30.41 \pm 0.37 \\
\mathrm{a}\end{array}$ & $\begin{array}{c}20.86 \pm 1.05 \\
b\end{array}$ & $\begin{array}{c}15.79 \pm 0.31 \\
\mathrm{c}\end{array}$ & $\begin{array}{c}6.11 \pm 0.27 \\
\mathrm{~d}\end{array}$ & $\begin{array}{c}4.69 \pm 1.06 \\
\mathrm{e}\end{array}$ \\
\hline
\end{tabular}

${ }^{a}$ Data are given as mean \pm SEM $(n=3)$. Mean values in columns with different letters indicate significant differences (Least Squared Difference test; $\mathrm{P}<0.05)$. ISP - isoelectric solubilization/precipitation; Chicken PI at $35^{\circ} \mathrm{C}$ - chicken protein isolate recovered with ISP at $32-34^{\circ} \mathrm{C}$; Chicken PI at $4^{\circ} \mathrm{C}$ - chicken protein isolate recovered with ISP at $4^{\circ} \mathrm{C}$. 
Table 3. Color properties ${ }^{a}$ of chicken gels.

\begin{tabular}{|c|c|c|c|}
\hline $\begin{array}{l}\text { Experimental } \\
\text { treatment code }^{b}\end{array}$ & $\mathbf{L}^{*}$ & $\mathbf{a}^{*}$ & $\mathbf{b}^{*}$ \\
\hline 1 & $83.4 \pm 1.3 b$ & $-0.7 \pm 0.4 \mathrm{f}$ & $17.2 \pm 0.9 \mathrm{~d}$ \\
\hline 2 & $81.3 \pm 0.9 \mathrm{c}$ & $-3.2 \pm 0.5 \mathrm{~g}$ & $12.2 \pm 0.9 \mathrm{~g}$ \\
\hline 3 & $77.0 \pm 0.5 \mathrm{e}$ & $3.3 \pm 0.3 \mathrm{ab}$ & $17.3 \pm 0.4 \mathrm{~d}$ \\
\hline 4 & $63.6 \pm 0.9 \mathrm{~h}$ & $3.9 \pm 0.2 \mathrm{a}$ & $17.6 \pm 0.8 \mathrm{~d}$ \\
\hline 5 & $70.5 \pm 0.4 \mathrm{~g}$ & $2.9 \pm 0.1 \mathrm{bc}$ & $20.6 \pm 0.3 \mathrm{a}$ \\
\hline 6 & $73.8 \pm 0.3 \mathrm{f}$ & $2.6 \pm 0.2 \mathrm{~cd}$ & $20.0 \pm 0.1 \mathrm{ab}$ \\
\hline 7 & $74.1 \pm 0.6 \mathrm{f}$ & $2.2 \pm 0.9 \mathrm{cde}$ & $19.0 \pm 1.0 \mathrm{c}$ \\
\hline 8 & $78.2 \pm 0.2 \mathrm{~d}$ & $1.7 \pm 0.1 \mathrm{e}$ & $19.2 \pm 0.3 \mathrm{bc}$ \\
\hline 9 & $80.9 \pm 0.3 \mathrm{c}$ & $2.9 \pm 0.2 \mathrm{bc}$ & $16.2 \pm 0.1 \mathrm{e}$ \\
\hline 10 & $78.9 \pm 0.2 \mathrm{~d}$ & $2.6 \pm 0.4 \mathrm{~cd}$ & $17.8 \pm 0.3 \mathrm{~d}$ \\
\hline 11 & $82.4 \pm 0.4 \mathrm{~b}$ & $2.8 \pm 0.2 \mathrm{bc}$ & $13.8 \pm 0.3 \mathrm{f}$ \\
\hline 12 & $87.0 \pm 0.2 \mathrm{a}$ & $2.1 \pm 0.2 \mathrm{de}$ & $14.2 \pm 0.3 \mathrm{f}$ \\
\hline
\end{tabular}

${ }^{a}$ Data are given as mean $\pm \operatorname{SEM}(n=3)$. Mean values in columns with different letters indicate significant differences (Least Squared Difference test; $\mathrm{P}<0.05$ ).

${ }^{b}$ Experimental treatment codes are shown in Table 1. 
Table 4. Texture profile analysis ${ }^{a}$ (TPA) of chicken gels.

\begin{tabular}{cccccc}
\hline $\begin{array}{c}\text { Experimental } \\
\text { treatment code }\end{array}$ & Springiness & Cohesiveness & Gumminess & Chewiness \\
\hline $\mathbf{1}$ & $2.00 \pm 0.13 \mathrm{a}$ & $0.72 \pm 0.08 \mathrm{abcd}$ & $1459 \pm 738 \mathrm{ab}$ & $2270 \pm 1258 \mathrm{abcd}$ \\
$\mathbf{2}$ & $1.94 \pm 0.02 \mathrm{a}$ & $0.67 \pm 0.05 \mathrm{cde}$ & $1481 \pm 293 \mathrm{ab}$ & $2879 \pm 565 \mathrm{a}$ \\
$\mathbf{3}$ & $2.00 \pm 0.07 \mathrm{a}$ & $0.61 \pm 0.02 \mathrm{de}$ & $1123 \pm 223 \mathrm{abcd}$ & $2239 \pm 437 \mathrm{abcd}$ \\
$\mathbf{4}$ & $2.03 \pm 0.13 \mathrm{a}$ & $0.67 \pm 0.09 \mathrm{bcde}$ & $538 \pm 263 \mathrm{ef}$ & $1064 \pm 543 \mathrm{ef}$ \\
$\mathbf{5}$ & $2.04 \pm 0.06 \mathrm{a}$ & $0.60 \pm 0.09 \mathrm{e}$ & $483 \pm 186 \mathrm{f}$ & $988 \pm 352 \mathrm{f}$ \\
$\mathbf{6}$ & $2.04 \pm 0.13 \mathrm{a}$ & $0.79 \pm 0.08 \mathrm{a}$ & $761 \pm 204 \mathrm{def}$ & $1508 \pm 386 \mathrm{def}$ \\
$\mathbf{7}$ & $1.93 \pm 0.01 \mathrm{a}$ & $0.77 \pm 0.03 \mathrm{ab}$ & $1420 \pm 82 \mathrm{ab}$ & $2726 \pm 160 \mathrm{ab}$ \\
$\mathbf{8}$ & $1.96 \pm 0.09 \mathrm{a}$ & $0.75 \pm 0.08 \mathrm{abcd}$ & $875 \pm 228 \mathrm{cdef}$ & $1830 \pm 264 \mathrm{cde}$ \\
$\mathbf{9}$ & $2.03 \pm 0.02 \mathrm{a}$ & $0.72 \pm 0.11 \mathrm{abc}$ & $1282 \pm 165 \mathrm{abc}$ & $2415 \pm 225 \mathrm{abc}$ \\
$\mathbf{1 0}$ & $1.93 \pm 0.01 \mathrm{a}$ & $0.73 \pm 0.03 \mathrm{abc}$ & $1015 \pm 167 \mathrm{bcde}$ & $1840 \pm 200 \mathrm{cde}$ \\
$\mathbf{1 1}$ & $2.01 \pm 0.02 \mathrm{a}$ & $0.65 \pm 0.03 \mathrm{cde}$ & $1036 \pm 43 \mathrm{bcd}$ & $2011 \pm 143 \mathrm{bcd}$ \\
$\mathbf{1 2}$ & $2.02 \pm 0.02 \mathrm{a}$ & $0.64 \pm 0.02 \mathrm{cde}$ & $1599 \pm 241 \mathrm{a}$ & $3013 \pm 327 \mathrm{a}$ \\
\hline
\end{tabular}

${ }^{a}$ Data are given as mean \pm SEM $(\mathrm{n}=3)$. Mean values in columns with different letters indicate significant differences (Least Squared Difference test; $\mathrm{P}<0.05$ ).

${ }^{b}$ Experimental treatment codes are shown in Table 1. 


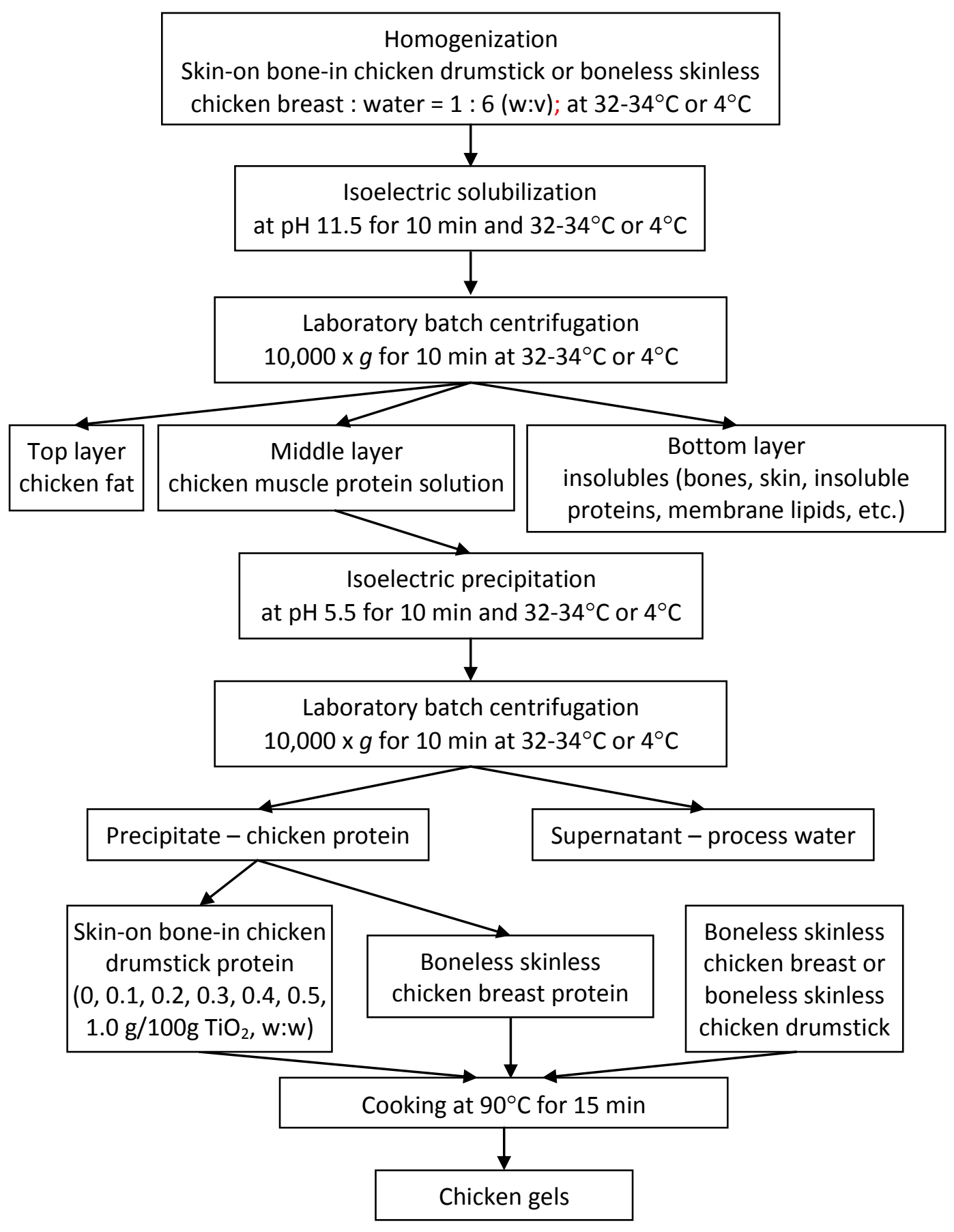

Figure 1. A flowchart for protein recovery and subsequent development of chicken gels. The gels were formulated to contain $78 \mathrm{~g} / 100 \mathrm{~g}$ moisture, $3 \mathrm{~g} / 100 \mathrm{~g}$ of potato starch (PS), $2 \mathrm{~g} / 100 \mathrm{~g} \mathrm{NaCl}$, $0.3 \mathrm{~g} / 100 \mathrm{~g}$ of polyphosphate (PP), and $\mathrm{pH}$ was adjusted to 7.2. Experimental treatments are shown in Table 1. 


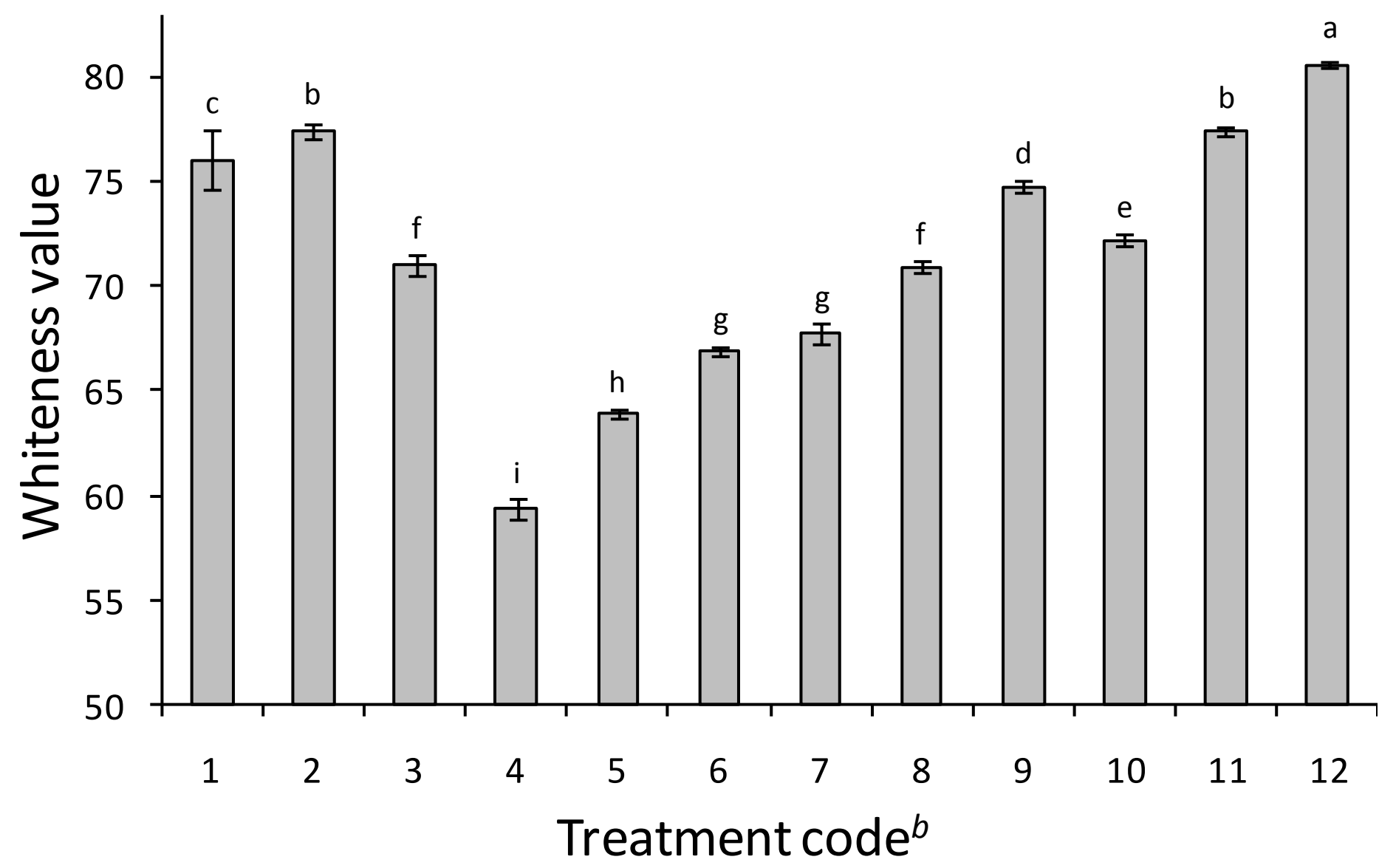

Figure 2. Whiteness ${ }^{a}$ of chicken gels. ${ }^{a}$ Data are given as mean $\pm \operatorname{SEM}(n=3)$. Different letters on the top of data bars indicate significant differences between mean values (Least Squared Difference test; $\mathrm{P}<0.05$ ).

${ }^{b}$ Experimental treatment codes are shown in Table 1. 


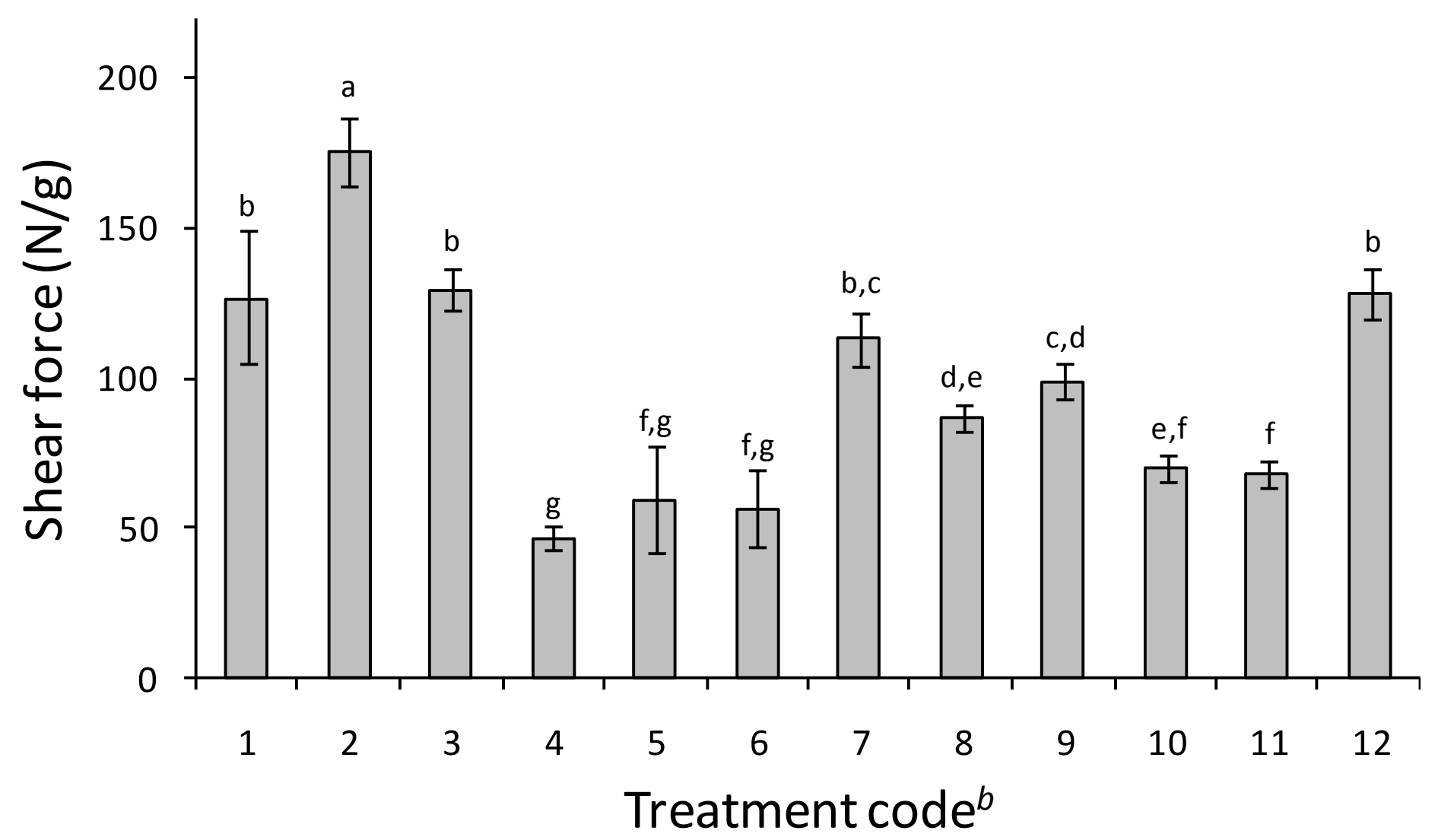

Figure 3. Kramer shear forcea of chicken gels. ${ }^{a}$ Data are given as mean \pm SEM $(n=3)$. Different letters on the top of data bars indicate significant differences between mean values (Least Squared Difference test; $\mathrm{P}<0.05)$.

${ }^{b}$ Experimental treatment codes are shown in Table 1. 


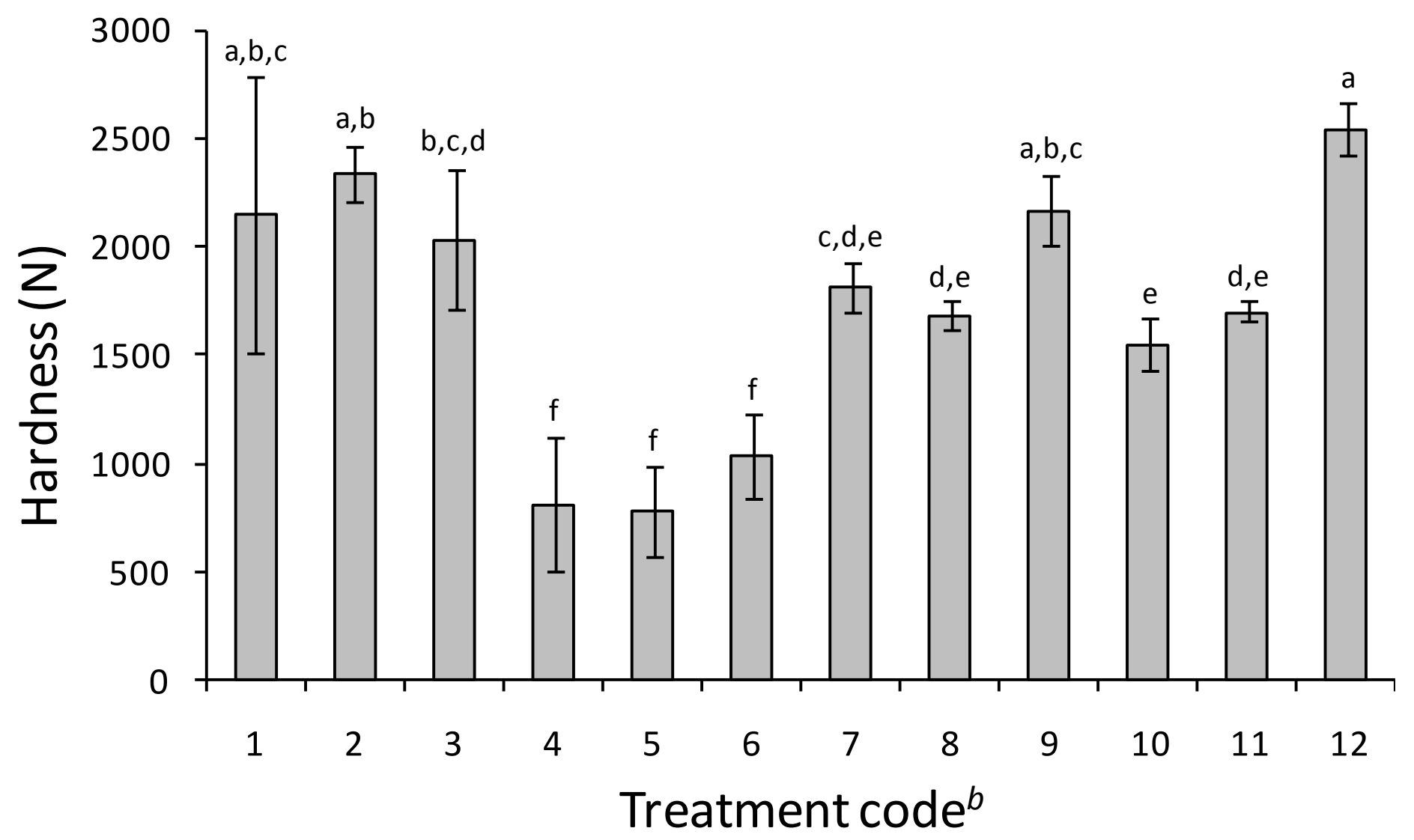

Figure 4. Hardness (Texture Profile Analysis) of chicken gels.

${ }^{a}$ Data are given as mean \pm SEM $(n=3)$. Different letters on the top of data bars indicate significant differences between mean values (Least Squared Difference test; $\mathrm{P}<0.05$ ).

${ }^{b}$ Experimental treatment codes are shown in Table 1. 


\section{CHAPTER 2}

Salt substitution in surimi seafood and its effects on instrumental quality attributes

Tahergorabi R, Beamer S, Matak K, Jaczynski, J. (2012). LWT - Food Science and Technology, DOI: 10.1016/j.lwt.2012.03.004. 


\begin{abstract}
A reduction of dietary sodium intake (i.e., from food products) is one of the strategies to decrease the risk for cardiovascular disease (CVD). Salt $(\mathrm{NaCl})$ is commonly added during processing of seafood products to enhance protein gelation, and hence, texture and flavor as well as to increase microbial safety. This study compared effects of salt substitute and salt on physicochemical properties of heat-set surimi gels. Salt or salt substitute at 0 (control), 0.17 , 0.34 , and $0.51 \mathrm{~mol} / \mathrm{L}$ was added to surimi. Addition of salt and salt substitute at 0.17 and 0.34 $\mathrm{mol} / \mathrm{L}$ greatly enhanced $(\mathrm{P}<0.05)$ gel texture. However, the level of enhancement was generally better with salt than with the salt substitute. Gel whiteness decreased $(\mathrm{P}<0.05)$ for surimi with salt at 0.34 and $0.51 \mathrm{~mol} / \mathrm{L}$ and salt substitute at $0.51 \mathrm{~mol} / \mathrm{L}$. Although salt and salt substitute exceeding $0.17 \mathrm{~mol} / \mathrm{L}$ lowered $(\mathrm{P}<0.05)$ gel lightness $\left(\mathrm{L}^{*}\right)$, they also generally reduced gel redness $\left(a^{*}\right)$ and yellowness $\left(b^{*}\right)$. Water activity of gels with salt and salt substitute was reduced $(\mathrm{P}<0.05)$, which is indicative of increased microbial safety. Addition of salt substitute greatly reduced $(\mathrm{P}<0.05)$ sodium content in surimi gels. This study demonstrated that salt substitute and salt resulted in similar physicochemical properties of surimi gels, but gels developed with salt substitute have much lower sodium content. Therefore, salt substitute can be used to replace $\mathrm{NaCl}$ in low-sodium surimi seafood products.
\end{abstract}

Keywords: surimi; texture; color; salt; salt substitute; food product development. 


\section{Introduction}

There is evidence that excessive dietary salt intake raises blood pressure, which is the major cause of cardiovascular disease (CVD) (World Health Organization, 2002; Intersalt Cooperative Research Group, 1988; Poulter et al., 1990; Forte, Miguel, Miguel, de Padua, \& Rose, 1989; He \& MacGregor, 2002; Lifton, 1996). Current average dietary sodium intake in the United States exceeds 3,400 mg/day, which is considerably higher than the recommended maximum intake level of 2,300 mg/day (United States Department of Agriculture, 2010). The Centres for Disease Control and Prevention (CDC) has proposed a limit of 1,500 mg/day (CDC, 2009). It has been estimated that approximately $70 \%$ of the recommended maximum daily sodium intake is added during food processing (Scientific Advisory Committee on Nutrition, 2003). Therefore, reduction or replacement of sodium at the food processing level has the greatest potential to reduce salt-related CVD.

Surimi is a concentrated fish myofibrillar protein mixed with cryoprotectants. Surimi is commercially prepared by washing deboned fish mince with water to remove blood, lipids, enzymes, and sarcoplasmic proteins (Suzuki, 1981; Vilhelmsson, 1997). Surimi is used as a main and functional ingredient in numerous seafood-flavored products such as crab-flavored seafood, seafood salads, and the like. During manufacturing of these products salt is required to extract myofibrillar proteins and consequently develop desired texture upon cooking. Salt also lowers water activity, and therefore, suppresses growth of foodborne pathogens. Surimi-based seafood products contain 1-3 g/100 g of salt. Recent trends indicate that many consumers are interested in reducing their dietary sodium intake. Thus, the development of low-sodium surimibased seafood products will allow processors diversification of their offerings by targeting this market. 
Efforts to reduce sodium in processed meat products have been aimed at the reduction or replacement of $\mathrm{Na}^{+}$with other cations such as $\mathrm{K}^{+}, \mathrm{Mg}^{2+}$ or $\mathrm{Ca}^{2+}$. Most attention has been focused on the use of potassium chloride (Gelabert, Gou, Guerrero, \& Arnau, 2003; Hand, Terrell, \& Smith, 1982; Ibanez, Quintanilla, Cid, Astiasaran, \& Bello, 1996; Ibanez, Quintanilla, Cid, Astiasaran, \& Bello, 1997; Ibanez et al., 1995; Riera, Martinez, Salcedo, Juncosa, \& Sellart, 1996; Ruusunen \& Puolanne, 2005). Unlike sodium, which increases hypertension, potassium has antihypertensive properties and much higher recommended maximum intake level than sodium (Na-2,300 mg/day, K - 4,700 mg/day) (Geleijnse, Witteman, Bak, den Breeijen, \& Grobbee, 1994; McGuire \& Beerman, 2007).

It is possible to reduce sodium content in surimi-based seafood products by replacing salt with a salt substitute. However, texture and color properties of surimi seafood drive consumer acceptance. It is necessary to determine the effect of salt substitution on these critical properties. To our knowledge there are no reports on this topic. Therefore, it is hypothesized that equal molar concentration of salt substitute and salt will results in similar texture and color properties of surimi-based seafood, but salt substitute will decrease sodium content. Specific objectives of this study were to compare (1) texture, (2) color, (3) water activity, and (4) sodium content of heat-set surimi gels made with salt substitute and salt.

\section{Materials and methods}

\section{Surimi}


Frozen Alaska pollock surimi grade A was purchased from Trident Seafoods Corp.

(Seattle, WA). Surimi contained cryoprotectants (4 g/100 g of sorbitol and $4 \mathrm{~g} / 100 \mathrm{~g}$ of sucrose), $0.15 \mathrm{~g} / 100 \mathrm{~g}$ of sodium tripolyphosphate, and $0.15 \mathrm{~g} / 100 \mathrm{~g}$ of tetrasodium pyrophosphate.

Frozen surimi blocks (10 kg each) were shipped overnight in heavily insulated industrial strength boxes filled with ice. Upon arrival surimi blocks were cut into approximately $800 \mathrm{~g}$ units, vacuum-packaged and stored at $-80^{\circ} \mathrm{C}$ until needed.

Preparation of surimi gels

Surimi gels with different concentration of salt and salt substitute were made by using a previously described procedure (Jaczynski \& Park, 2004; Taskaya, Chen, \& Jaczynski, 2009a). Frozen surimi was thawed at $4^{\circ} \mathrm{C}$ for $24 \mathrm{~h}$ followed by chopping in a universal food processor (Model UMC5, Stephan Machinery Corp., Columbus, $\mathrm{OH}$ ) at low speed for 1 min. In order to make surimi paste, myofibrillar proteins were extracted with salt (non-iodized Morton ${ }^{\circledR}$ salt, Morton International Inc., Chicago, IL) or KCl-based salt substitute (AlsoSalt ${ }^{\circledR}$ sodium-free salt substitute, AlsoSalt, Maple Valley, WA). The salt substitute contained $68 \mathrm{~g} / 100$ of $\mathrm{KCl}$ and Llysine mono-hydrochloride and calcium stearate. According to the manufacturer, the patented Llysine derivative masks the metallic-bitter aftertaste of $\mathrm{KCl}$. Salt was added to surimi at 10.0, 20.0, and $30.0 \mathrm{~g}$ per $1000 \mathrm{~g}$ batch. These concentrations of salt correspond to $0.17,0.34$, and $0.51 \mathrm{~mol} / \mathrm{L}$ of $\mathrm{NaCl}$, respectively. The molecular weight of $\mathrm{KCl}$ and $\mathrm{NaCl}$ is 74.5 and $58.5 \mathrm{~g}$, respectively. In order to add the same number of $\mathrm{KCl}$ and $\mathrm{NaCl}$ molecules to the surimi paste, salt substitute was added at the same, equal molar concentrations as salt. Thus, $0.17,0.34$, and $0.51 \mathrm{~mol} / \mathrm{L}$ correspond to $18.6,37.3$, and $55.9 \mathrm{~g}$ of salt substitute per $1000 \mathrm{~g}$ batch [e.g.; 0.17 
$\mathrm{mol} / \mathrm{L} * 74.5 \mathrm{~g} *(100 / 68)=18.6 \mathrm{~g}]$. Therefore, $18.6,37.3$, and $55.9 \mathrm{~g}$ of salt substitute were equal molar concentrations to $10.0,20.0$, and $30.0 \mathrm{~g}$ of $\mathrm{NaCl}$, respectively, added to $1000 \mathrm{~g}$ batch. Hereafter, only molar concentrations of salt and salt substitute will be used. After adding salt or salt substitute, chopping at low speed for 0.5 min resulted in surimi paste. A surimi batch without salt or salt substitute was also made and used as a control treatment. The experimental treatments are listed in Table 1.

Following chopping, final moisture content of surimi paste was adjusted to $78 \mathrm{~g} / 100 \mathrm{~g}$ by adding ice. Fish myofibrillar proteins are a gelling agent in surimi. The protein concentration along with moisture content is responsible for texture properties of heat-set surimi gels. Therefore, in order to maintain the same protein concentration and moisture content for all treatment groups, but variable concentration of salt and salt substitute, silicon dioxide $\left(\mathrm{SiO}_{2}\right)$ was added to surimi paste as inert filler (Table 1). Silicon dioxide is inert and does not contribute to texture development. This formulation allowed determination of salt and salt substitute contribution to gel texture without confounding factors associated with different protein concentration and water content. Crab-flavored surimi seafood typically contains crab flavor. Water-soluble crab flavor (F-11019, Activ International, Mitry-Mory Cedex, France) was added to the surimi paste at $3.7 \mathrm{~g} / 100 \mathrm{~g}$ (Perez-Mateos, Boyd, \& Lanier, 2004). Surimi paste with added ice, $\mathrm{SiO}_{2}$, and crab flavor was mixed in the universal food processor (Model UMC5, Stephan Machinery Corp., Columbus, $\mathrm{OH}$ ) at low speed for 1 min. Additional mixing was performed at high speed under vacuum $(50 \mathrm{kPa})$ for the last $3 \mathrm{~min}$. The paste temperature was controlled at $1-4^{\circ} \mathrm{C}$ during entire paste preparation.

The paste was extruded into stainless steel tubes $($ inner diameter $=1.9 \mathrm{~cm}$, length $=17.5$ $\mathrm{cm})$ with stainless steel screw end caps and heated in a water bath at $90^{\circ} \mathrm{C}$ for $15 \mathrm{~min}$. Following 
heating, tubes were chilled in ice slush and surimi gels were removed for analysis. The heat-set gels were used for determination of texture (Kramer shear test and texture profile analysis) and color (tristimulus color values $\mathrm{L}^{*} \mathrm{a}^{*} \mathrm{~b}$ ). The gels were also used to determine sodium and potassium content as well as water activity.

\section{Texture properties of surimi gels}

Two different methods were employed to determine texture: Kramer shear test and texture profile analysis (TPA). Although these measurements are commonly employed for determination of textural properties, each method provides slightly different information (Kim, Park, \& Yoon, 2005). The most comprehensive understanding of textural properties is provided by a combination of methods. Therefore, these two different tests were employed in the present study. Surimi gels were equilibrated to room temperature for $2 \mathrm{~h}$ prior to texture measurements.

At least eight cylindrical gels $($ height $=8.0 \mathrm{~cm}$, diameter $=1.9 \mathrm{~cm})$ per treatment were subjected to Kramer shear test using a texture analyzer (Model TA-HDi, Texture Technologies Corp., Scarsdale, NY) with a Kramer cell attachment (Taskaya, Chen, Beamer, \& Jaczynski, 2009b; Tahergorabi, Beamer, Matak, \& Jaczynski, 2011). The Kramer shear cell consisted of

five 3.0-mm thick and 70-mm wide shear blades passing through a cell having a corresponding number of slots. Individual gel samples were weighed and placed under the blades in the Kramer cell. Shear force was measured at a $127 \mathrm{~mm} / \mathrm{min}$ crosshead speed and expressed as maximum peak force ( $\mathrm{N}$ peak force/g of gel sample).

Texture profile analysis (TPA) of the gels was performed according to Cheret, Chapleau, Delbarre-Ladrat, Verrez-Bagnis, \& Lamballerie (2005). At least eight cylindrical gels (height $=$ 
$2.54 \mathrm{~cm}$, diameter $=1.90 \mathrm{~cm}$ ) per treatment were used for the TPA measurement. Gel samples were subjected to two-cycle compression at $50 \%$ compression using the texture analyzer with a 70-mm TPA compression plate attachment moving at a speed of $127 \mathrm{~mm} / \mathrm{min}$. From the resulting force-time curves, hardness, springiness, cohesiveness, gumminess, chewiness, and resilience were determined.

\section{Color properties of surimi gels}

The surimi gel samples were equilibrated to room temperature for $2 \mathrm{~h}$ prior to the color measurement. The color properties of heat-set surimi gels were determined using a Minolta Chroma Meter CR-300 colorimeter (Minolta Camera Co. Ltd., Osaka, Japan) calibrated with white calibration plate supplied by the manufacturer (Chen \& Jaczynski, 2007a; 2007b). At least eight cylindrical gels $($ height $=2.54 \mathrm{~cm}$, diameter $=1.90 \mathrm{~cm})$ per treatment were used for color measurements. The $\mathrm{L}^{*}$ (lightness) $\mathrm{a}^{*}$ (red to green) $\mathrm{b}^{*}$ (yellow to blue) tristimulus color values using CIE (Commission Internationale d'Eclairage of France) color system were determined. Whiteness of gels was calculated by the following equation (National Fisheries Institute, 1991; Taskaya, Chen, \& Jaczynski, 2010):

$$
\text { Whiteness }=100-\left[\left(100-\mathrm{L}^{*}\right)^{2}+\mathrm{a}^{*^{2}}+\mathrm{b}^{*^{2}}\right]^{1 / 2}
$$

Sodium and potassium content of surimi gels

All glassware was washed overnight in a solution of $0.3 \mathrm{~mol} \mathrm{~L}^{-1} \mathrm{HCl}$ in deionized

distilled water $\left(\mathrm{ddH}_{2} \mathrm{O}\right)$ prior to use. Ashed samples were dissolved in $2 \mathrm{~mL}$ of $7.7 \mathrm{~mol} \mathrm{~L}^{-1}$ nitric 
acid. The acidified samples were neutralized in $5 \mathrm{~mL}$ of $\mathrm{ddH}_{2} \mathrm{O}$ and filtered through Whatman \#1 paper (Whatman International Ltd., Maidstone, United Kingdom). Samples were diluted to volume with $\mathrm{ddH}_{2} \mathrm{O}$ in a $50 \mathrm{~mL}$ volumetric flask. Sodium and potassium content were determined using inductively coupled plasma optical emission spectrometry (model P400, Perkin Elmer, Shelton, $\mathrm{CN})$. The measurements were performed in triplicate and mean values \pm standard deviation are reported.

Water activity $\left(a_{w}\right)$ measurement

The surimi gel samples were equilibrated to $25^{\circ} \mathrm{C}$ for $2 \mathrm{~h}$ prior to the $\mathrm{a}_{\mathrm{w}}$ measurement. Water activity was measured at $25^{\circ} \mathrm{C}\left( \pm 0.2^{\circ} \mathrm{C}\right)$ using an electronic dew-point water activity meter (Aqualab Series 4 model TE, Decagon Devices, Pullman, WA). The $\mathrm{a}_{\mathrm{w}}$ meter was equipped with a temperature control to maintain a constant temperature and was calibrated with saturated salt solutions. The measurements were performed in triplicate and mean values \pm standard deviation are reported.

\section{Statistics}

The experiments were triplicated $(n=3)$. In each triplicate at least eight measurements were performed for determination of Kramer shear force, TPA, and color ( $\left.\mathrm{L}^{*} \mathrm{a}^{*} \mathrm{~b}^{*}\right)$; and at least three for $\mathrm{Na}$ and $\mathrm{K}$ content as well as $\mathrm{a}_{\mathrm{w}}$. Data were subjected to one-way analysis of variance (ANOVA). A significant difference was determined at 0.05 probability level and differences between treatments were tested using the Fisher's Least Significant Difference (LSD) test (Freud 
\& Wilson, 1997). All statistical analyses of data were performed using SAS (2002). The data are reported as mean values \pm standard deviation $(\mathrm{SD})$.

\section{Results and Discussion}

Texture properties of surimi gels

Kramer shear force is often used for texture measurements of gelled meat products including surimi-based seafood (Gehring, Gigliotti, Moritz, Tou, \& Jaczynski, 2011). Kramer shear is considered an empirical test (Kim et al., 2005). Surimi gels required higher $(\mathrm{P}<0.05)$ force to shear when salt or salt substitute was added up to $0.34 \mathrm{~mol} / \mathrm{L}$ (Fig. 1). However, the extent of this increase was generally slightly smaller for salt substitute. Salt and salt substitute at $0.51 \mathrm{~mol} / \mathrm{L}$ caused a decrease $(\mathrm{P}<0.05)$ of shear force when compared to 0.34 and $0.17 \mathrm{~mol} / \mathrm{L}$. Gels with salt substitute at $0.51 \mathrm{~mol} / \mathrm{L}$ resulted in similar $(\mathrm{P}>0.05)$ shear force to surimi gels without salt or salt substitute (i.e., control treatment). These results are in agreement with Martinez-Alvarez, Borderias, \& Gomez-Guillen's (2005) study who replaced $\mathrm{NaCl}$ with $\mathrm{KCl}$ in cod.

Hardness of surimi gels increased $(\mathrm{P}<0.05)$ when salt or salt substitute was added at all tested concentrations (Fig. 2). Salt $(\mathrm{NaCl})$ results in a compaction of the myofibrillar structure, which in part explains the increased hardness in the present study (Shomer, Weinberg, \& Vailiver, 1987). Similar to Kramer shear stress, the level of hardness increase was slightly smaller $(\mathrm{P}<0.05)$ when salt substitute was added to surimi. Gou, Guerrero, Gelabert, \& Arnau (1995) and Gimeno, Astiasaran, \& Bello (1999) also found that replacing $\mathrm{NaCl}$ with $\mathrm{KCl}$ results 
in softer texture of restructured meat products. Also, hardness of surimi gels decreased when $0.51 \mathrm{~mol} / \mathrm{L}$ of salt or salt substitute was added compared to 0.34 and $0.17 \mathrm{~mol} / \mathrm{L}$. The texture results from the present study are in agreement with salt replacement studies in fish products (Iseya, Sugiura, \& Saki, 1998) and dry-cured meat (Ruiz-Ramirez, Arnau, Serra, \& Gou, 2005; Andres, Cava, Ventanas, Thovar, \& Ruiz, 2004).

Szczesniak (1963) defined springiness as "the rate at which a deformed material goes back to its undeformed condition after the deforming force is removed" and cohesiveness as "the strength of the internal bonds making up the body of the product". In the present study, springiness of surimi gels with salt and salt substitute was similar ( $\mathrm{P}>0.05)$; however, much higher $(\mathrm{P}<0.05)$ compared to the control (Table 2$)$. Gel cohesiveness, gumminess, chewiness, and resilience were generally slightly lower when salt substitute was added compared to respective salt concentration, but much higher $(\mathrm{P}<0.05)$ compared to the control. Gimeno et al. (1999) showed similar trends.

Based on the texture data from the present study, $0.34 \mathrm{~mol} / \mathrm{L}$ of salt substitute may replace respective salt concentration in surimi-based seafood products.

\section{Color properties of surimi gels}

Surimi (mainly fish myofibrillar proteins) is used as a main and functional ingredient in surimi-based products. Proper color along with texture are two critical quality attributes for surimi-based products. Surimi is made by washing deboned fish mince with water to remove myoglobin, fat, and other impurities; thus, increasing lightness $\left(\mathrm{L}^{*}\right)$ and decreasing redness $\left(\mathrm{a}^{*}\right)$ and yellowness $\left(b^{*}\right)$. Table 3 shows the tristimulus color values $\left(\mathrm{L}^{*} \mathrm{a}^{*} \mathrm{~b}^{*}\right)$ of surimi gels made 
with salt and salt substitute. The $\mathrm{L}^{*}$ of surimi gels slightly decreased $(\mathrm{P}<0.05)$ from 88.7 to 86.8 and $\mathrm{a}^{*}$ decreased from 2.4 to -1.6 as salt concentration increased to $0.51 \mathrm{~mol} / \mathrm{L}$ (Table 3 ). As a result, whiteness of gels with salt slightly decreased $(\mathrm{P}<0.05)$ (Fig. 3). Kang, Hunt, \& Park (2008) also showed that addition of salt to Alaska pollock surimi decreases $(\mathrm{P}<0.05)$ whiteness.

Surimi gels with salt substitute had generally comparable $\mathrm{L}^{*}$ to the gels with respective salt concentration (Table 3). However, $\mathrm{a}^{*}$ and $\mathrm{b}^{*}$ were generally slightly lower than the control samples and gels with respective salt concentration. These results are in accordance with those obtained by Gimeno, Astiasaran, \& Bello (1999) who studied the effects of $\mathrm{NaCl}$ replacement with $\mathrm{KCl}$ on color of fermented sausage. In contrast, Gou, Guerrero, Gelabert, \& Arnau (1995) showed that substitution of $\mathrm{NaCl}$ with $\mathrm{KCl}$ in cured meat did not affect color. Leak, Kemp, Fox, \& Langlois (1987) studied the color of cured ham in which $\mathrm{NaCl}$ was replaced with $\mathrm{KCl}$. They concluded that subjective evaluations of color and general appearance were not affected. Although instrumental color differences were detected in the present study, these differences were small.

Na and K content of surimi gels

$\mathrm{Na}$ and $\mathrm{K}$ content of surimi gels are presented in Fig. 4. Significant reduction $(\mathrm{P}<0.05)$ of the $\mathrm{Na}$ content was achieved through the substitution of $\mathrm{NaCl}$ with the $\mathrm{KCl}$-based salt substitute. Potassium has antihypertensive properties, and therefore, may counteract the negative effects of $\mathrm{Na}$ associated with elevating blood pressure in humans (McGuire \& Beerman, 2007). The muscle of saltwater fish contains a variety of salts that are equivalent to a solution with an ionic strength of 0.11-0.15 mol/L NaCl (Stefansson \& Hultin, 1994; Lin \& Park, 1996). In addition, 
small amounts of various forms of $\mathrm{Na}$ phosphates are added to surimi with cryoprotectants. Therefore, a low level of $\mathrm{Na}$ is expected in surimi-based seafood products. The Na content of surimi gels with salt substitute was similar $(\mathrm{P}>0.05)$ to control gels (i.e., without salt or salt substitute) at approximately $100 \mathrm{mg} / 100 \mathrm{~g}$. The recommended maximum intake of $\mathrm{Na}$ is 2,300 $\mathrm{mg} / \mathrm{day}$. If salt substitute is used to manufacture surimi-based seafood and the serving size is $100 \mathrm{~g}$, such seafood would contribute $4 \%$ of the $2300 \mathrm{mg} /$ day maximum. In contrast, if salt is used at $0.17-0.51 \mathrm{~mol} / \mathrm{L}$ (equivalent of $1-3 \%$ ), the 100-g serving of such seafood would contribute $16-44 \%$ of the $2300 \mathrm{mg}$ /day maximum.

According to the Dietary Reference Intakes from the Institute of Medicine, the Adequate Intake of potassium is 4,700 mg/day (McGuire \& Beerman, 2007). In the present study surimi gels made with salt substitute at $0.17,0.34$, and $0.51 \mathrm{~mol} / \mathrm{L} \mathrm{KCl}$ contained 395,670 , and 1033 $\mathrm{mg} / 100 \mathrm{~g}$ of $\mathrm{K}$, respectively; while gels made with salt contained under $30 \mathrm{mg} / 100 \mathrm{~g}$ of K (Fig. 4). It has been estimated that a $600 \mathrm{mg}$ /day increase of dietary $\mathrm{K}$ intake lowers blood pressure by $133 \mathrm{~Pa}$ (ICRG, 1988). Also, increasing current K intake to the recommended level may reduce the risk of stroke mortality by $8-15 \%$ and the risk of heart disease mortality by $6-11 \%$ (ICRG, 1988). This is of similar magnitude to what can be achieved by lowering dietary Na intake and highlights the importance of dietary strategies focusing on a simultaneous reduction of $\mathrm{Na}$ intake and increase of $\mathrm{K}$ intake.

Water activity $\left(a_{w}\right)$ of surimi gels

Salt $(\mathrm{NaCl})$ preserves food by reducing $\mathrm{a}_{\mathrm{w}}$. The $\mathrm{a}_{\mathrm{w}}$ is a measure of water in food that is available for microbial growth and chemical reactions (Aberoumand, 2010). The $\mathrm{a}_{\mathrm{w}}$ for surimi 
gels is shown in Table 4. One of the problems associated with using $\mathrm{NaCl}$ substitutes in restructured meat products is that the $\mathrm{a}_{\mathrm{w}}$ reduction may not be as strong as with $\mathrm{NaCl}$ ( $\mathrm{Ruiz}$, 2007). In the present study, salt and salt substitute reduced $(\mathrm{P}<0.05) \mathrm{a}_{\mathrm{w}}$ in surimi gels. The differences in $\mathrm{a}_{\mathrm{w}}$ between gels with salt and the salt substitute could be due to the fact that $\mathrm{NaCl}$ decreases $\mathrm{a}_{\mathrm{w}}$ more than $\mathrm{KCl}$. The values of parameter " $\mathrm{B}$ " characterizing electrolytes in the Pitzer-Bromley $\mathrm{a}_{\mathrm{w}}$ model are 0.057 and 0.024 for $\mathrm{NaCl}$ and $\mathrm{KCl}$, respectively. The $\mathrm{a}_{\mathrm{w}}$ results from the present study are also in agreement with Zanardi, Ghidini, Conter, \& Ianieri (2010) and Alino et al. (2010) who studied the effects of $\mathrm{NaCl}$ replacement on physicochemical properties of salami and dry-cured loins, respectively.

\section{Conclusion}

The results indicate that surimi gels developed with salt substitute contained significantly less sodium, while their texture and color could be considered acceptable although slight modifications were detected. This study points towards the potential for a reduced sodium surimi-based seafood product; however, sensory tests and storage stability study are recommended. 


\section{References}

Aberoumand, A. (2010). The effect of water activity on preservation quality of fish, a review article. World Journal of Fish and Marine Sciences, 2(3), 221-225.

Alino, M., Grau, R., Toldra, F., Blesa, E., Pagan, J., Jose, M., \& Barat, M. (2010).

Physicochemical properties and microbiology of dry-cured loins obtained by partial sodium replacement with potassium, calcium and magnesium. Meat Science, 85, 580-588.

Andres, A., Cava, R., Ventanas, J., Thovar, V., \& Ruiz, J. (2004). Sensory characteristics of Iberian ham: Influence of salt content and processing conditions. Meat Science, 68, 45-51.

Centers for Disease Control and Prevention. (2009). Americans consume too much salt. Available from: http://www.cdc.gov/media/pressrel/2009/r090326.htm. Accessed March 7, 2011.

Chen, Y.C., \& Jaczynski, J. (2007a). Gelation of protein recovered from whole Antarctic krill (Euphausia superba) by isoelectric solubilization/precipitation as affected by functional additives. Journal of Agricultural and Food Chemistry, 55, 1814-1822.

Chen, Y.C., \& Jaczynski, J. (2007b). Protein recovery from rainbow trout (Oncorhynchus mykiss) processing by-products via isoelectric solubilization / precipitation and its gelation properties as affected by functional additives. Journal of Agricultural and Food Chemistry, 55, 9079-9088.

Cheret, R., Chapleau, N., Delbarre-Ladrat, C., Verrez-Bagnis, V., \& Lamballerie, M.D. (2005). Effects of high pressure on texture and microstructure of sea bass (Dicentrarchus labrax L.) fillets. Journal of Food Science, 70, E477-483.

Forte, J.G., Miguel, J.M., Miguel, M.J., de Padua, F., \& Rose, G. (1989). Salt and blood pressure: A community trial. Journal of Human Hypertension, 3, 179-184.

Freud, R.J., \& Wilson, W.J. (1997). Design of experiments (p 464). San Diego (CA): Academic Press.

Gelabert, J., Gou, P., Guerrero, L., \& Arnau, J. (2003). Effect of sodium chloride replacement on some characteristics of fermented sausages. Meat Science, 65, 833-839.

Geleijnse, J.M., Witteman, J.C., Bak, A.A., den Breeijen, J.H., \& Grobbee, D.E. (1994). Reduction in blood pressure with a low sodium, high potassium, high magnesium salt in older subjects with mild to moderate hypertension. British Medical Journal, 309, 436-440.

Gehring, C.K., Gigliotti, J.C., Moritz, J.S., Tou, J.C., \& Jaczynski, J. (2011). Functional and nutritional characteristics of proteins and lipids recovered by isoelectric processing of fish byproducts and low-value fish - a review. Food Chemistry, 124(2), 422-431. 
Gimeno, O., Astiasaran, I., \& Bello, J. (1999). Influence of partial replacement of NaCl with $\mathrm{KCl}$ and $\mathrm{CaCl}_{2}$ on texture and color of dry fermented sausages. Journal of Agricultural and Food Chemistry, 47, 873-877.

Gou P., Guerrero, L., Gelabert, J., \& Arnau, J. (1995). Potassium chloride, potassium lactate and glycine as sodium chloride substitutes in fermented sausages and in dry-cured pork loin. Meat Science, 42, 37-48.

Hand, L.W., Terrell, R.N., \& Smith, G.C. (1982). Effects of chloride salts on physical, chemical and sensory properties of frankfurters. Journal of Food Science, 47, 1800-1802.

He, F.J., \& MacGregor, G.A. (2002). Effect of modest salt reduction on blood pressure: a meta analysis of randomized trial. Journal of Human Hypertension, 16, 761-770.

Ibanez, C., Quintanilla, L., Irigoyen, A., Garcia-Jalon, I., Cid, C., Astiasaran, I., et al. (1995). Partial replacement of $\mathrm{NaCl}$ with $\mathrm{KCl}$ in dry fermented sausages: Influence on carbohydrate fermentation and the nitrosation process. Meat Science, 40, 45-53.

Ibanez, C., Quintanilla, L., Cid, C., Astiasaran, I., \& Bello, J. (1996). Dry fermented sausages elaborated with Lactobacillus plantarum - Staphylococcus carnosus part I: Effect of partial replacement of $\mathrm{NaCl}$ with $\mathrm{KCl}$ on the stability and the nitrosation process. Meat Science, 44(4), 227-234.

Ibanez, C., Quintanilla, L., Cid, C., Astiasaran, I., \& Bello, J. (1997). Dry fermented sausages elaborated with Lactobacillus plantarum - Staphylococcus carnosus. Part II: Effect of partial replacement of $\mathrm{NaCl}$ with $\mathrm{KCl}$ on the proteolytic and insolubilization processes. Meat Science, 46(3), 277-284.

Intersalt Cooperative Research Group. (1988). Intersalt: an international study of electrolyte excretion and blood pressure. Results for 24 hour urinary sodium and potassium excretion. British Medical Journal, 297, 319-328.

Iseya, Z., Sugiura, S., \& Saeki, H. (1998). Effect of curing with NaCl solution on drying characteristics of fish meat and its textural changes during drying. Fisheries Science, 64(6), 969-972.

Jaczynski, J., \& Park, J.W. (2004). Physicochemical changes in Alaska pollock surimi and surimi gel as affected by electron beam. Journal of Food Science, 69, 53-57.

Kang, E.J., Hunt, A.L., \& Park, J.W. (2008). Effects of salinity on physicochemical properties of Alaska Pollock surimi after repeated freeze-thaw cycles. Journal of Food Science, 73(5), C347-355.

Kim, B.Y., Park, J.W., \& Yoon, W.B. (2005). Rheology and texture properties of surimi gels. In J.W. Park, Surimi and Surimi Seafood, $2^{\text {nd }}$ ed. (p 491-582). Boca Raton (FL): Taylor and Francis Group. 
Leak, F.W., Kemp, J.D., Fox, J., Langlois D. (1987). Effects of boning time, mechanical tenderization and partial replacement of sodium chloride on the quality and microflora of boneless dry-cured ham. Journal of Food Science, 52, 263-266.

Lifton, R.P. (1996). Molecular genetics of human blood pressure variation. Science, 272, 676680 .

Lin, T.M., \& Park, J.W. (1996) Extraction of proteins from Pacific whiting mince at various washing conditions. Journal of Food Science, 61, 432-438.

Martinez-Alvarez, O., Borderias, A.J., Gomez-Guillen, M.C. (2005). Sodium replacement in the cod (Gadus morhua) muscle salting process. Food Chemistry, 93, 125-133.

McGuire, M., \& Beerman, K.A. (2007). Nutritional sciences, From fundamentals to food. Belmont (CA): Thomson Learning, (Chapter 13).

National Fisheries Institute. (1991). A Manual of Standard Methods for Measuring and Specifying the Properties of Surimi. Washington (D.C.): National Fisheries Institute.

Perez-Mateos, M., Boyd, L., \& Lanier, T. (2004). Stability of omega-3 fatty acids in fortified surimi seafoods during chilled storage, Journal of Agricultural and Food Chemistry, 52, 79447949.

Poulter, N.R., Khaw, K.T., Hopwood, B.E., Mugambi, M., Peart, W.S., Rose, G., et al. (1990). The Kenyan law migration study: Observation on the initiation of a rise in blood pressure. British Medical Journal, 300, 967-972.

Riera, J.B., Martinez, M.R., Salcedo, R.C., Juncosa, G.M., \& Sellart, J.C. (1996). Process for producing a low sodium meat product. U.S. Patent and Trademark Office, patent number $5,534,279$.

Ruusunen, M., \& Puolanne, E. (2005). Reducing sodium intake from meat products. Meat Science, 70, 531-541.

Ruiz, J. (2007). Ingredients. In F. Toldra (Ed.), Handbook of fermented meat and poultry (pp. 59-76). Iowa, USA: Blackwell Publishing.

Ruiz-Ramirez, J., Arnau, J., Serra, X., Gou, P. (2005). Relationship between water content, $\mathrm{NaCl}$ content, $\mathrm{pH}$ and texture parameters in dry-cured muscles, Meat Science, 70, 579-587.

SAS Institute. (2002). SAS/STAT guide for personal computers, version 8.1. Cary (NC):SAS Institute.

Scientific advisory committee on nutrition. (2003). Salt and health. Norwich, UK: The Stationary Office. 
Shomer, I., Weinberg, Z.G., \& Vasiliver, R. (1987). Structural binding properties of silver carp (Hypophtalmicthys molitrix) muscle affected by $\mathrm{NaCl}$ and $\mathrm{CaCl}_{2}$ treatments. Food Microstructure, 6, 199-207.

Stefansson, G., \& Hultin, H.O. (1994). On the solubility of cod muscle in water. Journal of Agricultural and Food Chemistry, 42, 2656-2664.

Suzuki, T. (1981). Fish and krill protein: processing technology, pp. 31-34, Applied Science Publishers, London, UK.

Szczesniak, A. S. (1963). Classification of textural characteristics. Journal of Food Science, 28, 385-389.

Tahergorabi, R., Beamer, S.K., Matak, K.E., \& Jaczynski, J. (2011). Effect of isoelectric solubilization/precipitation and titanium dioxide on whitening and texture of proteins recovered from dark chicken-meat processing by-products. LWT-Food Science and Technology 44(4), 896-903.

Taskaya, L., Chen, Y. C., \& Jaczynski, J. (2009a). Functional properties of proteins recovered from whole gutted silver carp (Hypophthalmichthys molitrix) by isoelectric solubilization / precipitation. LWT - Food Science and Technology, 42(6), 1082-1089.

Taskaya, L., Chen, Y.C., Beamer, S., \& Jaczynski, J. (2009b). Texture and color properties of proteins recovered from whole gutted silver carp (Hypophthalmichthys molitrix) using isoelectric solubilisation / precipitation. Journal of the Science of Food and Agriculture, 89(2), 349-358.

Taskaya, L., Chen, Y.C., \& Jaczynski, J. (2010). Color improvement by titanium dioxide and its effect on gelation and texture of proteins recovered from whole fish using isoelectric solubilization/precipitation. LWT - Food Science and Technology, 43(3), 401-408.

United States Department of Agriculture. 2011. Dietary guidelines for Americans, 2010. Available from http://health.gov/dietaryguidelines/2010.asp. Accessed February 8, 2012.

Vilhelmsson, O. (1997). The state of enzyme biotechnology in the fish processing industry. Trends in Food Science and Technology, 8, 266-270.

World Health Organization. (2002). World Health Report 2002. Reducing risks, promoting healthy life. Geneva, Switzerland. Available at: http://www.who.int/whr/2002. Accessed February 20, 2010.

Zanardi, E., Ghidini, S., Conter, M., Ianieri, A. (2010). Mineral composition of Italian salami and effect of $\mathrm{NaCl}$ partial replacement on compositional, physico-chemical and sensory parameters. Meat Science, 86, 742-74. 
Table 1. Final batter formulations. Batters with different levels of salt and salt substitute were formulated to contain $78 \mathrm{~g} / 100 \mathrm{~g}$ moisture and equal amount of protein, water, and water-based crab flavor by using inert filler, silicon dioxide $\left(\mathrm{SiO}_{2}\right)$. The three levels of addition of salt and salt substitute were standardized based on equal molar concentration. Salt contained over $99 \mathrm{~g} / 100 \mathrm{~g} \mathrm{NaCl}$ and salt substitute contained $68 \mathrm{~g} / 100 \mathrm{~g} \mathrm{KCl}$; molecular weight $\left(\mathrm{M}_{\mathrm{w}}\right)$ of $\mathrm{NaCl}=58.5 \mathrm{~g}$ and $\mathrm{M}_{\mathrm{w}}$ of $\mathrm{KCl}=74.5 \mathrm{~g}$. Batch size was $1000 \mathrm{~g}$.

\begin{tabular}{|c|c|c|c|c|c|c|c|c|}
\hline \multicolumn{2}{|c|}{ SALT } & \multicolumn{2}{|c|}{ SALT SUBSTITUTE } & \multirow[b]{2}{*}{$\begin{array}{c}\text { Filler }-\mathrm{SiO}_{2} \\
\text { (g/1000 g) }\end{array}$} & \multirow[b]{2}{*}{$\begin{array}{c}\text { Surimi } \\
\text { (g/1000 g) }\end{array}$} & \multirow[b]{2}{*}{$\begin{array}{c}\text { Water } \\
\text { (g/1000 g) }\end{array}$} & \multirow[b]{2}{*}{$\begin{array}{l}\text { Crab flavor } \\
\text { (g/1000 g) }\end{array}$} & \multirow[b]{2}{*}{$\begin{array}{c}\text { Batch weight } \\
\text { (g) }\end{array}$} \\
\hline $\begin{array}{c}\text { Molar } \\
\text { concentration }\end{array}$ & $\begin{array}{l}\text { Weight } \\
\text { (g/1000 g) }\end{array}$ & $\begin{array}{c}\text { Molar } \\
\text { concentration }\end{array}$ & $\begin{array}{l}\text { Weight } \\
\text { (g/1000 g) }\end{array}$ & & & & & \\
\hline 0.0 (control) & 0.0 (control) & 0.0 (control) & 0.0 (control) & 55.9 & 656.4 & 250.7 & 37.0 & 1000.0 \\
\hline $0.17 \mathrm{~mol} / \mathrm{L}$ & 10.0 & 0.0 & 0.0 & 45.9 & 656.4 & 250.7 & 37.0 & 1000.0 \\
\hline $0.34 \mathrm{~mol} / \mathrm{L}$ & 20.0 & 0.0 & 0.0 & 35.9 & 656.4 & 250.7 & 37.0 & 1000.0 \\
\hline $0.51 \mathrm{~mol} / \mathrm{L}$ & 30.0 & 0.0 & 0.0 & 25.9 & 656.4 & 250.7 & 37.0 & 1000.0 \\
\hline 0.0 & 0.0 & $0.17 \mathrm{~mol} / \mathrm{L}$ & 18.6 & 37.3 & 656.4 & 250.7 & 37.0 & 1000.0 \\
\hline 0.0 & 0.0 & $0.34 \mathrm{~mol} / \mathrm{L}$ & 37.3 & 18.6 & 656.4 & 250.7 & 37.0 & 1000.0 \\
\hline 0.0 & 0.0 & $0.51 \mathrm{~mol} / \mathrm{L}$ & 55.9 & 0.0 & 656.4 & 250.7 & 37.0 & 1000.0 \\
\hline
\end{tabular}


Table 2. Effect of salt and salt substitute on texture profile analysis* (TPA) of surimi gels.

\begin{tabular}{|c|c|c|c|c|c|c|c|}
\hline & Control & $\begin{array}{c}0.17 \mathrm{~mol} / \mathrm{L} \\
\mathrm{NaCl}\end{array}$ & $\begin{array}{c}0.34 \mathrm{~mol} / \mathrm{L} \\
\mathrm{NaCl}\end{array}$ & $\begin{array}{c}0.51 \mathrm{~mol} / \mathrm{L} \\
\mathrm{NaCl}\end{array}$ & $\begin{array}{c}0.17 \mathrm{~mol} / \mathrm{L} \\
\text { salt substitute }\end{array}$ & $\begin{array}{c}0.34 \mathrm{~mol} / \mathrm{L} \\
\text { salt substitute }\end{array}$ & $\begin{array}{c}0.51 \mathrm{~mol} / \mathrm{L} \\
\text { salt substitute }\end{array}$ \\
\hline Springiness & $1.45 \pm 0.49 \mathrm{~b}$ & $2.03 \pm 0.01 \mathrm{a}$ & $1.99 \pm 0.02 \mathrm{a}$ & $2.01 \pm 0.02 \mathrm{a}$ & $2.05 \pm 0.01 \mathrm{a}$ & $2.00 \pm 0.10 \mathrm{a}$ & $2.04 \pm 0.01 \mathrm{a}$ \\
\hline Cohesiveness & $0.37 \pm 0.03 d$ & $0.69 \pm 0.01 b$ & $0.72 \pm 0.02 a$ & $0.69 \pm 0.02 b$ & $0.66 \pm 0.02 c$ & $0.66 \pm 0.02 c$ & $0.65 \pm 0.02 c$ \\
\hline Gumminess & $195 \pm 26 f$ & $1262 \pm 78 a$ & $1290 \pm 131 \mathrm{a}$ & $1136 \pm 100 \mathrm{~b}$ & $1028 \pm 99 \mathrm{c}$ & $931 \pm 81 \mathrm{~d}$ & $791 \pm 64$ e \\
\hline Chewiness & $394 \pm 52 f$ & $2550 \pm 163 a$ & $2491 \pm 278 a$ & $2281 \pm 199 \mathrm{~b}$ & $2104 \pm 206 c$ & $1857 \pm 199 d$ & $1618 \pm 131 \mathrm{e}$ \\
\hline Resilience & $0.48 \pm 0.06 \mathrm{a}$ & $0.38 \pm 0.01 b c$ & $0.40 \pm 0.02 \mathrm{~b}$ & $0.38 \pm 0.01 b c$ & $0.35 \pm 0.01 d$ & $0.36 \pm 0.01 \mathrm{~d}$ & $0.36 \pm 0.01 \mathrm{~cd}$ \\
\hline
\end{tabular}

* Data are given as mean \pm SD $(n=3)$. Mean values in rows with different letters indicate significant differences (Least Squared

Difference test; $\mathrm{P}<0.05)$. 
Table 3. Effect of salt and salt substitute on color properties* of surimi gels.

\begin{tabular}{|c|c|c|c|c|c|c|c|}
\hline & Control & $\begin{array}{c}0.17 \mathrm{~mol} / \mathrm{L} \\
\mathrm{NaCl}\end{array}$ & $\begin{array}{c}0.34 \mathrm{~mol} / \mathrm{L} \\
\mathrm{NaCl}\end{array}$ & $\begin{array}{c}0.51 \mathrm{~mol} / \mathrm{L} \\
\mathrm{NaCl}\end{array}$ & $\begin{array}{c}0.17 \mathrm{~mol} / \mathrm{L} \\
\text { salt substitute }\end{array}$ & $\begin{array}{c}0.34 \mathrm{~mol} / \mathrm{L} \\
\text { salt substitute }\end{array}$ & $\begin{array}{c}0.51 \mathrm{~mol} / \mathrm{L} \\
\text { salt substitute }\end{array}$ \\
\hline$L^{*}$ & $88.9 \pm 0.3 a$ & $88.7 \pm 0.6 \mathrm{a}$ & $87.4 \pm 1.0 \mathrm{~b}$ & $86.8 \pm 0.3 c$ & $88.9 \pm 0.8 \mathrm{a}$ & $87.1 \pm 0.4$ bc & $80.0 \pm 0.6 d$ \\
\hline$a^{*}$ & $0.9 \pm 0.4 \mathrm{~b}$ & $2.37 \pm 1.2 \mathrm{a}$ & $-0.5 \pm 0.04 c$ & $-1.6 \pm 0.04$ e & $-1.0 \pm 0.04 d$ & $-1.8 \pm 0.04$ e & $-3.6 \pm 0.04 f$ \\
\hline$b^{*}$ & $7.7 \pm 0.2 b$ & $6.8 \pm 1.0 \mathrm{c}$ & $8.2 \pm 0.2 \mathrm{a}$ & $6.3 \pm 0.2 \mathrm{~d}$ & $7.7 \pm 0.4 \mathrm{ab}$ & $5.2 \pm 0.1 \mathrm{e}$ & $1.7 \pm 0.4 \mathrm{f}$ \\
\hline
\end{tabular}

* Data are given as mean \pm SD $(n=3)$. Mean values in rows with different letters indicate significant differences (Least Squared Difference test; $\mathrm{P}<0.05)$. 
Table 4. Effect of salt and salt substitute on water activity $\left(\mathrm{A}_{\mathrm{w}}\right)$ of surimi gels.

\begin{tabular}{|c|c|c|c|c|c|c|c|}
\hline & Control & $\begin{array}{c}0.17 \mathrm{~mol} / \mathrm{L} \\
\mathrm{NaCl}\end{array}$ & $\begin{array}{c}0.34 \mathrm{~mol} / \mathrm{L} \\
\mathrm{NaCl}\end{array}$ & $\begin{array}{c}0.51 \mathrm{~mol} / \mathrm{L} \\
\mathrm{NaCl}\end{array}$ & $\begin{array}{c}0.17 \mathrm{~mol} / \mathrm{L} \\
\text { salt substitute }\end{array}$ & $\begin{array}{c}0.34 \mathrm{~mol} / \mathrm{L} \\
\text { salt substitute }\end{array}$ & $\begin{array}{c}0.51 \mathrm{~mol} / \mathrm{L} \\
\text { salt substitute }\end{array}$ \\
\hline$A_{w}$ & $\begin{array}{c}0.991 \pm 0.001 \\
a\end{array}$ & $\begin{array}{c}0.985 \pm 0.003 \\
\text { bc }\end{array}$ & $\begin{array}{c}0.985 \pm 0.002 \\
\text { bc }\end{array}$ & $\begin{array}{c}0.983 \pm 0.002 \\
c\end{array}$ & $\begin{array}{c}0.988 \pm 0.001 \\
a b\end{array}$ & $\begin{array}{c}0.991 \pm 0.004 \\
a\end{array}$ & $\begin{array}{c}0.970 \pm 0.005 \\
d\end{array}$ \\
\hline
\end{tabular}

* Data are given as mean \pm SD $(n=3)$. Mean values in rows with different letters indicate significant differences (Least Squared

Difference test; $\mathrm{P}<0.05)$. 


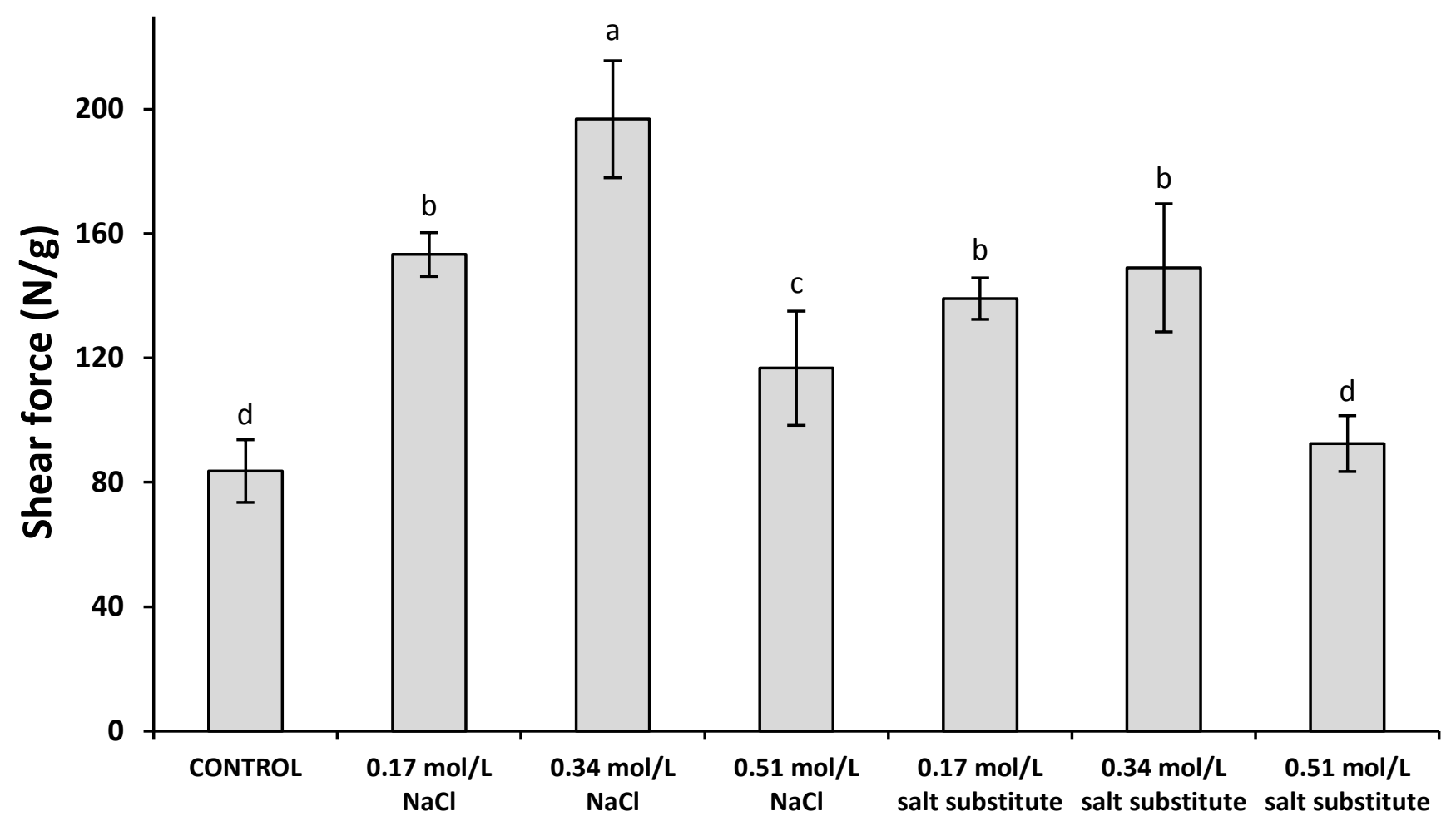

Figure 1. Effect of salt and salt substitute on Kramer shear force* of surimi gels.

* Data are given as mean \pm SD $(n=3)$. The small bars of the top of data bars indicate SD. Different letters on the top of SD bars indicate significant differences between mean values (Least Squared Difference test; $\mathrm{P}<0.05$ ). 


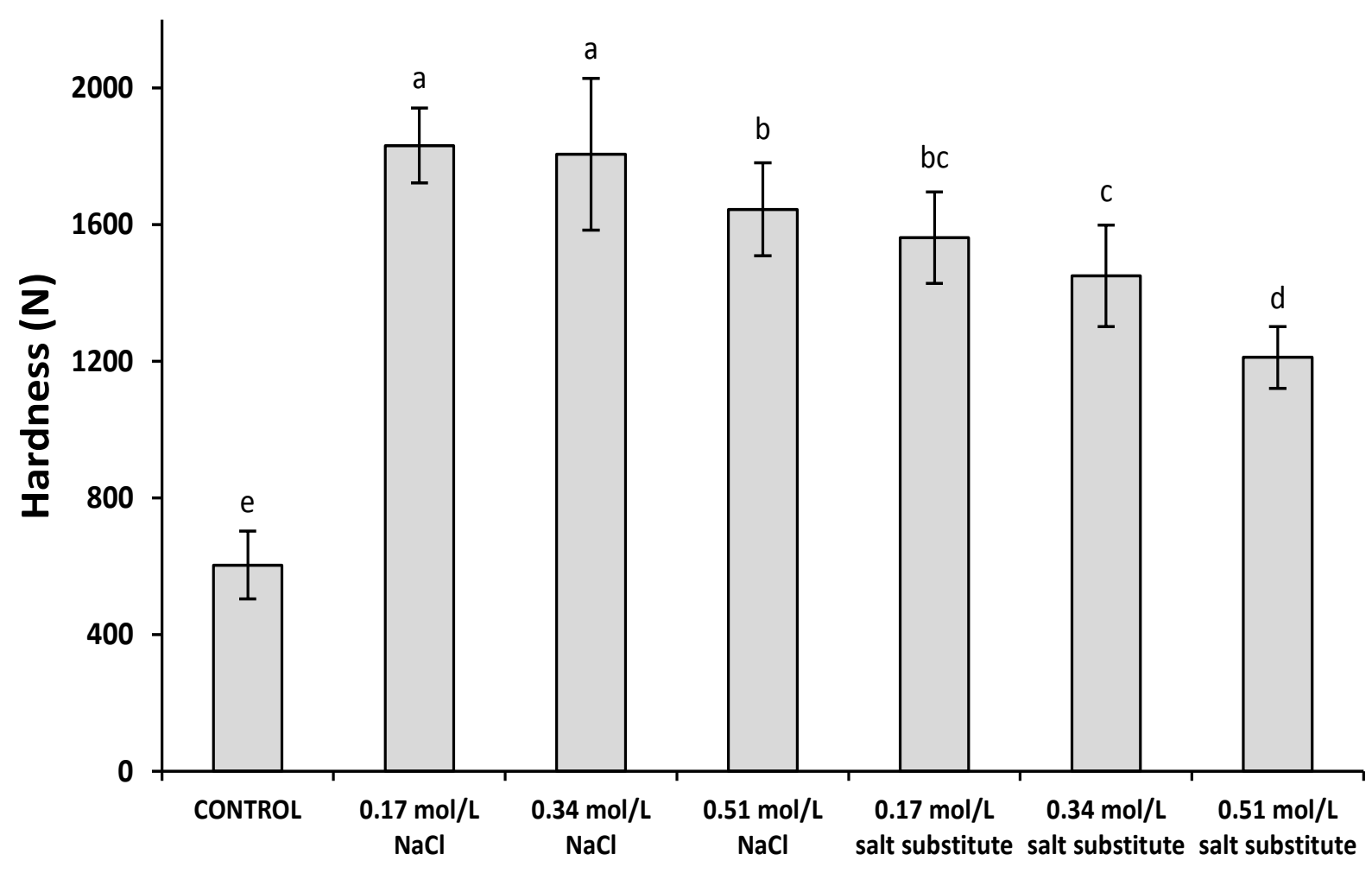

Figure 2. Effect of salt and salt substitute on hardness* of surimi gels.

* Data are given as mean \pm SD $(n=3)$. The small bars of the top of data bars indicate SD. Different letters on the top of SD bars indicate significant differences between mean values (Least Squared Difference test; $\mathrm{P}<0.05$ ). 


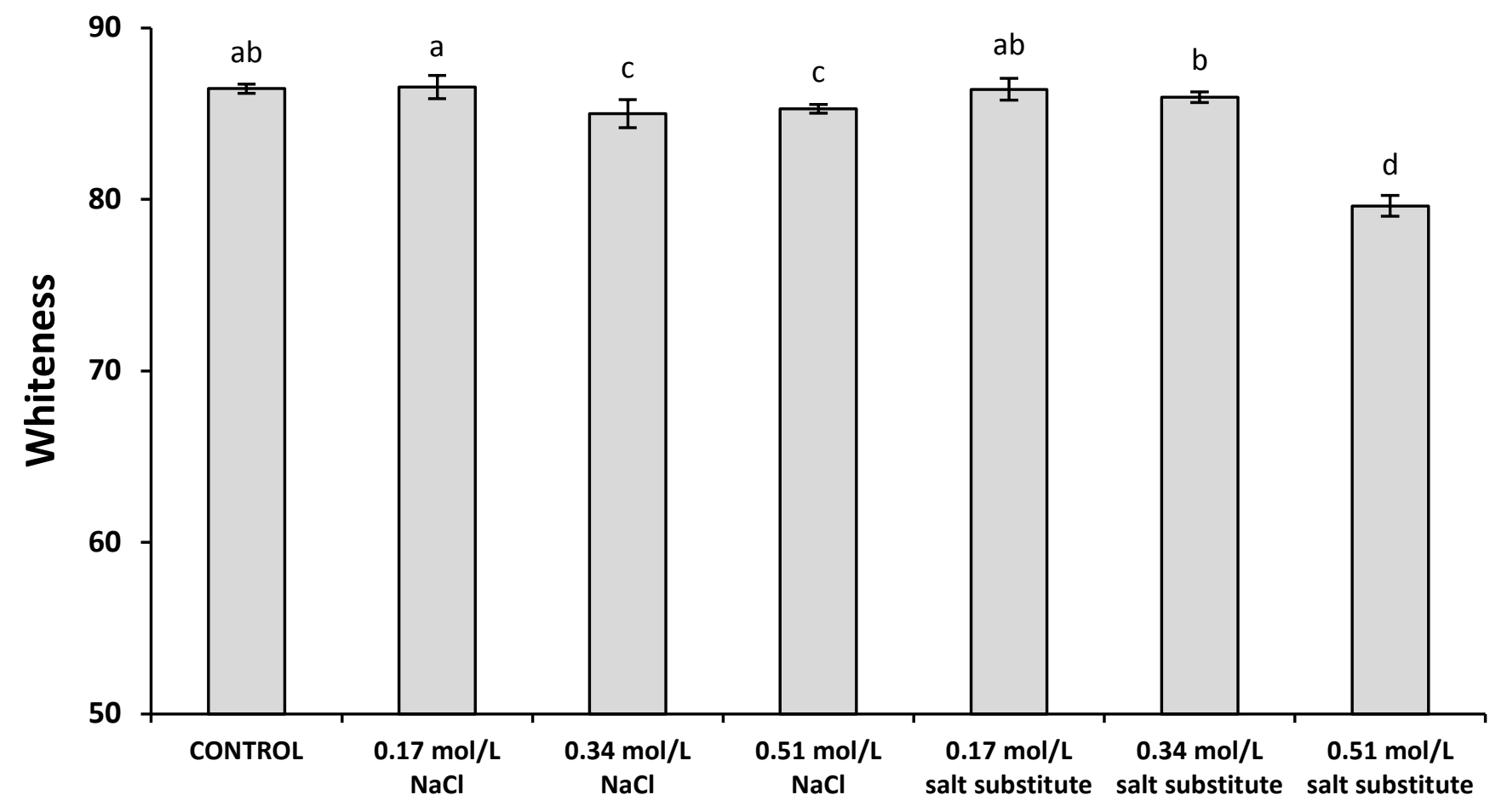

Figure 3. Effect of salt and salt substitute on whiteness* of surimi gels.

* Data are given as mean \pm SD $(n=3)$. The small bars of the top of data bars indicate SD. Different letters on the top of SD bars indicate significant differences between mean values (Least Squared Difference test; $\mathrm{P}<0.05$ ). 


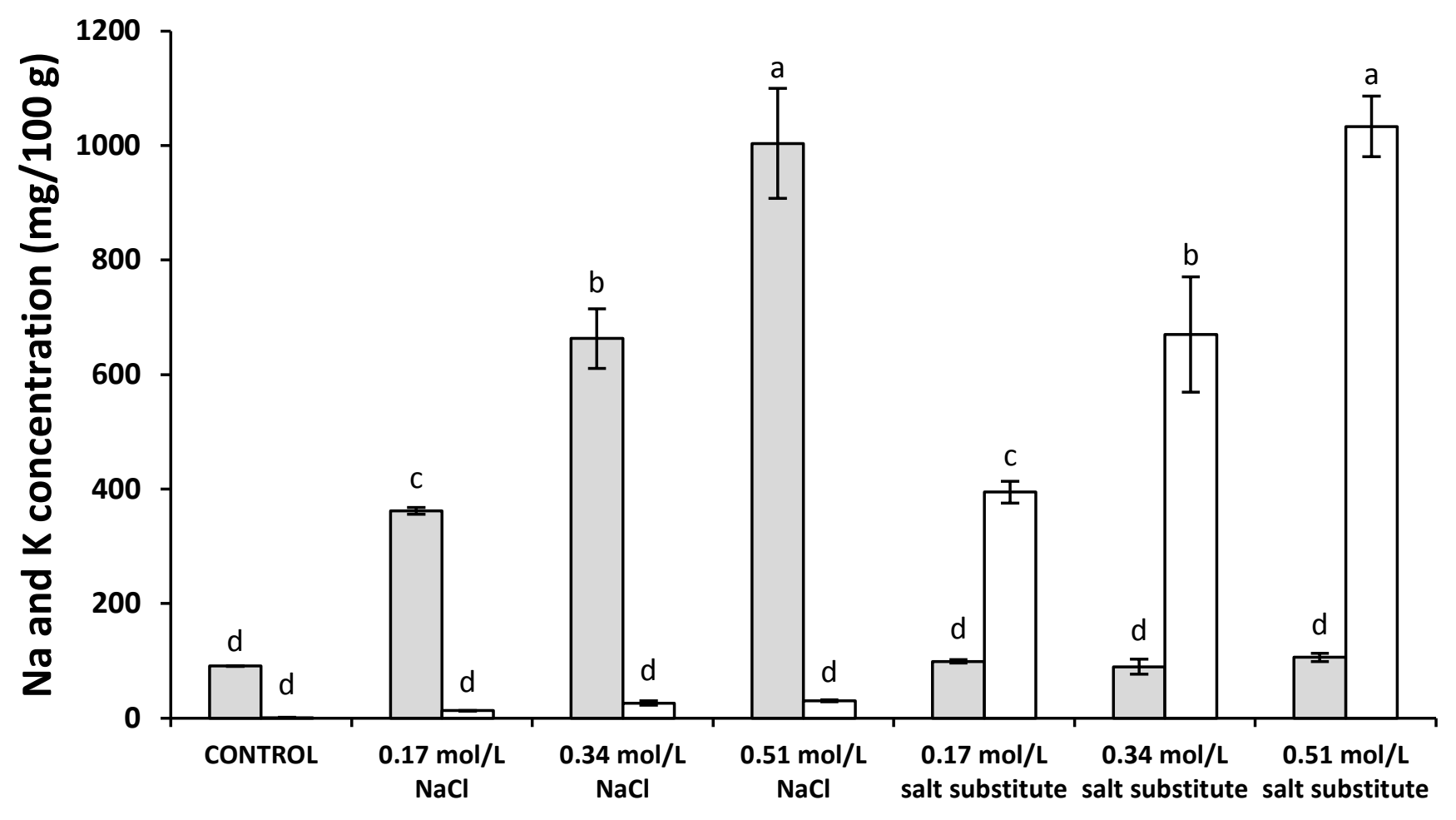

Figure 4. Effect of salt and salt substitute on sodium* and potassium* content of surimi gels.

* Data are given as mean \pm SD $(n=3)$. The small bars of the top of data bars indicate SD. Different letters on the top of SD bars indicate significant differences between mean values within sodium or potassium content (Least Squared Difference test; $\mathrm{P}<0.05$ ). 


\section{CHAPTER 3}

Physicochemical changes in surimi with salt substitute

Tahergorabi R, Jaczynski, J. (2012).Food Chemistry.132: 1281-1286 


\begin{abstract}
Excessive consumption of sodium in processed food products containing salt $(\mathrm{NaCl})$ contributes to cardiovascular disease (CVD). Surimi-based seafood products are processed foods widely accepted worldwide. A reduction of dietary sodium intake (i.e., from processed food) is a strategy to decrease the risk for CVD. However, salt extracts myofibrillar proteins contributing to protein gelation, and therefore, proper texture in surimi-based seafood. Low-sodium products are one of the current trends in favor with many health-conscious consumers. Therefore, it is desirable, to develop reduced-sodium surimi-based seafood without affecting protein gelation and texture. In this study, protein endothermic transitions (thermal denaturation), rheological properties (protein gelation), and fundamental texture properties (shear stress and strain at mechanical fracture) of Alaska pollock surimi gels made with 0 (control), 1, 2, and $3 \mathrm{~g} / 100$ of salt $(\mathrm{NaCl})$ were determined and compared with equal molar concentration of salt substitute. Salt and salt substitute shifted the onset of myosin transition to higher temperature and resulted in larger myosin peaks (i.e., transition enthalpy). Endothermic transitions showed similar trends to rheological properties. The elastic modulus $\left(G^{\prime}\right)$ increased when salt or salt substitute was added to surimi except the highest concentration of salt and salt substitute. Salt and salt substitute also induced the onset of protein gelation (i.e., as measured by significant increase of G') at lower temperature. Surimi gels with salt substitute and salt at equal molar concentrations had similar texture properties (shear stress and strain). Based on the present study, salt substitute can be used in the development of low-sodium surimi seafood products without significant change in gelation and texture. However, sensory and microbial storage stability studies are also recommended.
\end{abstract}


Key Words: Surimi; salt substitute; differential scanning calorimetry; rheology; texture

\section{Introduction}

The health impacts of excessive sodium consumption have been well-researched including high blood pressure, heart disease, and stroke. It has been estimated that processed food products are responsible for $80 \%$ of the excessive sodium consumption in the United States. This is why reduction or replacement of salt $(\mathrm{NaCl})$ at the food processing level has the greatest potential to reduce sodium-related health issues. Food processors have been under increasing pressure to reduce sodium content in food products. However, this presents challenges for sensory quality and food safety of processed food products. The American Heart Association (AHA), Centres for Disease Control and Prevention (CDC), and the U.S. Food and Drug Administration (FDA) have been working on sodium reduction in processed food products by $50 \%$ (CDC, 2009).

Restructured fish products such as surimi-based flavored seafood products are examples of typical processed foods. Salt $(\mathrm{NaCl})$ at $2-3 \mathrm{~g} / 100 \mathrm{~g}$ is typically added during manufacturing of surimi seafood. Among many functions, salt extracts fish myofibrillar proteins in surimi resulting in a viscous protein paste that transitions into elastic surimi gel during cooking, and thus, proper texture and other sensory attributes are developed in final surimi seafood products. Salt concentration is critical because it affects the amount of extracted surimi protein, and therefore, has an effect on protein gelation. Less salt typically has a negative effect on the functional and mechanical properties of restructured fish products such as surimi seafood (Pedro \& Nunes, 2007; Tahergorabi et al., 2011b). 
In general, strategies for reducing sodium content in processed food products have focused on: (1) lowering the concentration of added salt $(\mathrm{NaCl})$; (2) replacing all or part of the salt ( $\mathrm{NaCl})$ by other chloride salts $\left(\mathrm{KCl}, \mathrm{CaCl}_{2}\right.$, and $\left.\mathrm{MgCl}_{2}\right)$, flavors, and preservatives; and (3) combinations of the above approaches. Most attention has been focused on $\mathrm{KCl}$. Many commercial products utilize $\mathrm{KCl}$ as a partial replacer for $\mathrm{NaCl}$ (Gelabert, Gou, Guerrero, \& Arnau, 2003; Riera, Martinez, Salcedo, Juncosa, \& Sellart, 1996; Ruusunen \& Puolanne, 2005). Unlike sodium, which increases hypertension, $\mathrm{K}$ has antihypertensive properties and much higher recommended maximum intake level than sodium (sodium - 2,300 mg/day, potassium 4,700 mg/day) (Geleijnse, Witteman, Bak, den Breeijen, \& Grobbee, 1994; McGuire \& Beerman, 2007).

Similar to other muscle protein sources, fish myofibrillar proteins have the ability to form a stable 3-dimensional gel network when subjected to heat. Ionic strength (i.e., type of salt and its concentration) is an important factor that influences protein behavior during cooking, affecting protein endothermic transitions (i.e., protein thermal denaturation), rheological properties (i.e., protein gelation), and ultimately texture. Textural properties are one of the critical quality attributes for surimi seafood. Many studies have qualitatively compared the changes in endothermic transitions and rheological properties of seafood proteins during heatinduced gelation (Autio, Kiesvaara, \& Polvinen, 1989; Hamann, 1992; Yoon, Kim, \& Park, 1999; Kim \& Park, 2000; Benjakul, Visessanguan, Ishizaki, \& Tanaka, 2001a; Ni, Nozawa, \& Seki, 2001; Ferry, 1980). The fundamental texture properties, shear stress and strain of surimi seafood gels can be determined with torsion test at mechanical fracture (Kim, Park, \& Yoon, 2005). Torsion test strongly correlates with sensory tests (Hamann \& MacDonald, 1992). Differential scanning calorimetry (DSC) and oscillatory dynamic rheology are typically used to 
determine protein endothermic transitions (thermal denaturation) and rheological properties (protein gelation), respectively.

It is hypothesized that salt $(\mathrm{NaCl})$ and equal molar concentration of $\mathrm{KCl}$-based salt substitute will result in similar endothermic transitions, rheological properties, and texture of surimi gels. To test this hypothesis, surimi pastes with 1,2 , and $3 \mathrm{~g} / 100 \mathrm{~g}$ of salt $(\mathrm{NaCl})$ and equal molar concentrations of KCl-based salt substitute were prepared, heated, and their properties determined and compared. The objectives of this study were to compare (1) protein endothermic transitions (thermal denaturation) using DSC (2) rheological properties (protein gelation) using oscillatory dynamic rheometer, and (3) fundamental texture properties using torsion shear stress and strain at mechanical fracture of heat-set surimi gels made with salt $(\mathrm{NaCl})$ and $\mathrm{KCl}$-based salt substitute.

\section{Materials and Methods}

Surimi

Frozen Alaska pollock surimi grade A was purchased from Trident Seafoods Corp. (Seattle, WA). Surimi contained cryoprotectants (4 g/100 g of sorbitol and $4 \mathrm{~g} / 100 \mathrm{~g}$ of sucrose), $0.15 \mathrm{~g} / 100 \mathrm{~g}$ of sodium tripolyphosphate, and $0.15 \mathrm{~g} / 100 \mathrm{~g}$ of tetrasodium pyrophosphate. Frozen surimi blocks (10 kg each) were shipped overnight in heavily insulated industrial strength boxes filled with ice. Upon arrival surimi blocks were cut into approximately $800 \mathrm{~g}$ units, vacuum-packaged and stored at $-80^{\circ} \mathrm{C}$ until needed. 
Preparation of Alaska pollock surimi paste

Surimi pastes with different concentration of salt $(\mathrm{NaCl})$ and $\mathrm{KCl}$-based salt substitute were prepared by using a previously described procedure (Jaczynski \& Park, 2003; 2004; Taskaya, Chen, \& Jaczynski, 2009; 2010). Frozen surimi was thawed at $4^{\circ} \mathrm{C}$ for $24 \mathrm{~h}$ followed by chopping in a universal food processor (Model UMC5, Stephan Machinery Corp., Columbus, $\mathrm{OH})$ at low speed for $1 \mathrm{~min}$. In order to make surimi paste, myofibrillar proteins were extracted with $\mathrm{NaCl}$ (non-iodized Morton $®$ salt, Morton International Inc., Chicago, IL) (hereafter called salt) or KCl-based salt substitute (AlsoSalt ${ }^{\circledR}$ sodium-free salt substitute, AlsoSalt, Maple Valley, WA) (hereafter called salt substitute). The salt substitute contained $68 \mathrm{~g} / 100$ of $\mathrm{KCl}$ and Llysine mono-hydrochloride and calcium stearate. According to the manufacturer, the patented Llysine derivative masks the metallic-bitter aftertaste of $\mathrm{KCl}$. Salt was added to surimi at 10.0, 20.0 , and $30.0 \mathrm{~g}$ per $1000 \mathrm{~g}$ batch $(0.17,0.34$, and $0.51 \mathrm{M}$ of $\mathrm{NaCl}$, respectively). In order to add the same number of $\mathrm{KCl}$ and $\mathrm{NaCl}$ molecules to the surimi paste, salt substitute was added at the same, equal molar concentrations as salt. Thus, $0.17,0.34$, and $0.51 \mathrm{M}$ correspond to 18.6, 37.3, and $55.9 \mathrm{~g}$ of salt substitute per $1000 \mathrm{~g}$ batch [e.g.; $0.17 \mathrm{M} * 74.5 \mathrm{~g} *(100 / 68)=18.6 \mathrm{~g}$; molecular weight of $\mathrm{KCl}=74.5]$. Hereafter, only molar concentrations of salt and salt substitute will be used. After adding salt or salt substitute, chopping at low speed for 0.5 min resulted in surimi paste. A surimi paste without salt or salt substitute was also prepared and used as a control treatment. The experimental treatments are listed in Table 1.

Following chopping, final moisture content of surimi paste was adjusted to $78 \mathrm{~g} / 100 \mathrm{~g}$ by adding water (ice). Fish myofibrillar proteins are a gelling agent in surimi. The protein concentration along with moisture content is responsible for texture properties of heat-set surimi 
gels. Therefore, in order to maintain the same protein concentration and moisture content for all treatment groups, but variable concentration of salt and salt substitute, silicon dioxide $\left(\mathrm{SiO}_{2}\right)$ was added to surimi paste as inert filler (Table 1). Silicon dioxide is inert and does not contribute to texture development. This formulation allowed determination of salt and salt substitute contribution to the gel texture without confounding factors associated with different protein concentration and water content. Crab-flavored surimi seafood typically contains crab flavor. Water-soluble crab flavor (F-11019, Activ International, Mitry-Mory Cedex, France) was added to the surimi paste at $3.7 \mathrm{~g} / 100 \mathrm{~g}$ (Perez-Mateos, Boyd, \& Lanier, 2004). Surimi paste with added water (ice), $\mathrm{SiO}_{2}$, and crab flavor was mixed in the universal food processor (Model UMC5, Stephan Machinery Corp., Columbus, $\mathrm{OH}$ ) at low speed for 1 min. Additional mixing was performed at high speed under vacuum $(0.5 \mathrm{bar})$ for the last $3 \mathrm{~min}$. The paste temperature was controlled at $1-4^{\circ} \mathrm{C}$ during entire paste preparation.

Pastes prepared in this manner were used to determine protein endothermic transitions with a differential scanning calorimeter and rheological properties (storage modulus, G') with a dynamic rheometer as well as to develop surimi gels for torsion test.

\section{Differential scanning calorimetry (DSC)}

Alaska pollock surimi pastes were tested to determine the net heat energy (enthalpy, $\Delta \mathrm{H}$ ) as well as the onset $\left(\mathrm{T}_{\text {onset }}\right)$ and maximum $\left(\mathrm{T}_{\max }\right)$ temperatures for endothermic transitions of myosin and actin using differential scanning calorimeter (DSC Infinity Series F5010, Instrument Specialists, Inc., Spring Grove, IL). Approximately $20 \mathrm{mg}$ of surimi paste was hermetically sealed in an aluminum pan and scanned between 20 and $90^{\circ} \mathrm{C}$ at a heating rate of $10^{\circ} \mathrm{C} / \mathrm{min}(\mathrm{Park}$ 
\& Lanier, 1989; Yongswatdigul \& Park., 2004; Taskaya et al., 2009). Careful attention was paid to ensure good contact between the paste sample and the bottom of the aluminum pan. Temperature calibrations were performed prior to measurements according to the manufacturer and an empty pan was used as reference. The thermogram, $\Delta \mathrm{H}(\mathrm{J} / \mathrm{g}), \mathrm{T}_{\text {onset }}\left({ }^{\circ} \mathrm{C}\right)$, and $\mathrm{T}_{\max }\left({ }^{\circ} \mathrm{C}\right)$ are reported as mean values of five DSC measurements per treatment.

\section{Oscillatory dynamic rheology}

The non-destructive gelation properties of Alaska pollock surimi pastes were determined using a cone and plate geometry attached to a dynamic rheometer (Bohlin CVOR 200, Malvern Instruments Ltd., Worcestershire, UK) in oscillation mode. Once the sample was pressed by lowering the cone, the excess sample was removed. The gap between the cone and peltier plate was adjusted to $150 \mu \mathrm{m}$. The storage modulus (G') was measured with a temperature increasing from 25 to $90^{\circ} \mathrm{C}$ at the heating rate of $1^{\circ} \mathrm{C} / \mathrm{min}$ (Chen \& Jaczynski 2007a; 2007b; Taskaya et al., 2009). Tests were conducted at $1 \%$ strain and $0.1 \mathrm{~Hz}$ frequency. A plastic cover supplied by the manufacturer was used to prevent moisture evaporation during measurement. The rheogram is reported as a mean value of three measurements of elastic modulus $(\mathrm{kPa})$ per treatment.

\section{Development of Alaska pollock surimi gels for torsion test}

Following formulation, surimi pastes were separately stuffed into hour-glass pre-molded stainless steel torsion tubes $($ length $=17.5 \mathrm{~cm}$, end diameter $=1.9 \mathrm{~cm}$, midsection diameter $=1.0$ $\mathrm{cm}$ ) with screw end caps for determination of shear stress and strain at mechanical fracture using 
torsion test (Kassis, Drake, Beamer, Matak, \& Jaczynski, 2010; Pietrowski, Tahergorabi, Matak, Tou, \& Jaczynski, 2011). The tubes were heated in a water bath at $90^{\circ} \mathrm{C}$ for $15 \mathrm{~min}$. Following heating, tubes were chilled in ice slush and surimi gels were removed for the torsion test. Torsion test was performed according to the previously described procedure (Tahergorabi et al., 2011a). The gel samples were equilibrated to room temperature for $2 \mathrm{~h}$ prior to the measurement. At least eight hour-glass gels $($ length $=2.9 \mathrm{~cm}$, end diameter $=1.9 \mathrm{~cm}$, and midsection diameter $=1.0 \mathrm{~cm}$ ) per treatment were subjected to torsional shear using a Hamman Gelometer (Gel Consultant, Raleigh, NC) set at $2.5 \mathrm{rpm}$. Shear stress (kPa) and shear strain (no units, the ratio between gel's deformation length and gel's initial length) at mechanical fracture were measured to determine gel strength and gel cohesiveness, respectively (Kim et al., 2005).

There are several types of texture measurements, with each method providing slightly different information. Torsion test is considered a fundamental test for texture, while for example texture profile analysis (TPA) and Kramer shear test are empirical tests (Kim et al., 2005). Therefore, torsion test is a preferred methodology for determination of fundamental texture properties.

\section{Statistics}

The experiments were independently triplicated $(n=3)$. In each triplicate at least five DSC tests, three storage modulus measurements, and eight torsion tests were performed. A significant difference was determined at 0.05 probability level and differences between treatments were tested using the Fisher's Least Significant Difference (LSD) test (Freud \& Wilson, 1997). All statistical analyses of data were performed using SAS (2002). The data are reported as mean values \pm standard deviation (SD). 


\section{Results and Discussion}

\section{Endothermic transitions of surimi proteins}

Differential scanning calorimetry (DSC) is often employed to study the effects of various treatments on thermal behavior of seafood proteins and other protein sources. Thermal unfolding, the initial event of protein denaturation, requires heat input (i.e., endothermic reaction) that disrupts hydrogen bonds stabilizing the 3-dimentional, native structure (Privalov \& Khechinashvili, 1974). Surimi is manufactured by extensive washing of mechanically deboned and minced fish muscle to remove impurities including sarcoplasmic proteins. Therefore, surimi contains mainly myofibrillar proteins. Surimi is the main and functional ingredient in the restructured seafood products called surimi seafood (e.g., crab-flavored seafood). The surimi myofibrillar proteins in their native structure typically have excellent gel-forming ability, a protein functionality that surimi seafood depends on for the development of the desired texture (Park \& Lanier, 1989).

Endothermic transitions of surimi myofibrillar proteins with added salt and salt substitute are shown in Fig. 1 and Table 2. DSC detects endothermic peaks representing heat uptake by the protein structure as it gradually unfolds upon heating and transitions into its denatured structure (Spink, 2008). There are typically two peaks. The first peak corresponds to endothermic transition of myosin and the second to actin (Wright, Leach, \& Wilding, 1977). A typical thermogram for surimi without salt or salt substitute (control in Fig. 1) was recorded showing the onset of myosin transition at $31^{\circ} \mathrm{C}$ (Table 2). It is important to note that at this resolution of DSC, the actin peak for was not detected. The addition of salt and salt substitute shifted 
endothermic transition of myosin to higher temperature and resulted in larger size of myosin peaks (and $\Delta \mathrm{H}$ ). This suggests that in the presence of salt or salt substitute myosin requires more heat (i.e., higher temperature) to initiate unfolding, but once started, it unfolds to a greater extent. This greater extent of myosin unfolding is likely indicative of its lower stability due to increased salt concentration. Salt caused more profound transition of myosin than the salt substitute as shown by the greater size of myosin peaks (and $\Delta \mathrm{H}$ ) even though salt and salt substitute were added to surimi at the same molar concentration (i.e., the same number of $\mathrm{NaCl}$ and $\mathrm{KCl}$ molecules). These findings are in accordance with Fernandez-Martin, Fernandez, Carballo, \& Jimenez-Colmenero (2000) who reported that addition of salt $(\mathrm{NaCl})$ to pork and chicken meat batters increased the onset temperature and extent of protein denaturation. In contrast, Park and Lanier (1989) showed that salt addition shifted protein transition to lower temperature and decreased the transition enthalpy $(\Delta \mathrm{H})$.

\section{Dynamic rheological properties of surimi proteins}

Unlike other heat-set food gels, surimi gels exhibit rubber-like elastic properties at high water content (>75\%) because surimi myofibrillar proteins efficiently form covalent and noncovalent bonds (Niwa, 1992; Lee, Lanier, \& Hamann, 1997; Benjakul et al., 2001a; Benjakul, Visessanguan, \& Srivilai 2001b). This elastic behavior translates into textural properties of surimi seafood, one of the most critical quality attributes. Thus, rheology is the primary technique for quality control of surimi seafood. The elastic modulus (G') is a measure of gel's ability to be non-permanently deformed. The G' is often employed to characterize a transition from viscous protein paste to a solid, but elastic gel. 
A typical G' pattern for Alaska pollock surimi paste was recorded (Fig. 2). When salt or salt substitute was added to surimi the G' showed only marginal change until $55^{\circ} \mathrm{C}$, followed by a marked increase which leveled at approximately $75^{\circ} \mathrm{C}$. However, for surimi without salt or salt substitute, the marked increase started at about $60^{\circ} \mathrm{C}$ and stabilized at $80^{\circ} \mathrm{C}$. The increase in elasticity (i.e., G') has been attributed to the ordered protein aggregation followed by formation of the 3-dimentional gel network with water entrapped in the gel matrix (Dileep, Shamasundar, Binsi, Badii, \& Howell, 2005). Addition of salt or salt substitute resulted in increased G' (except $0.51 \mathrm{M}$ ) when compared to the control treatment (i.e., no salt or salt substitute), which confirms larger myosin DSC peaks (Fig. 1). However, G' decreased with increasing the salt and salt substitute concentration. This decrease might have been due to denaturation of the myosin tail (light mermyosin) which induced the redistribution of inter- and intra-molecular forces, thereby weakening the elastic component of the pre-gel structure and leading to increased fluidity (Egelansdal, Martinsen, \& Autio, 1995).

Overall, the G' patterns for Alaska pollock surimi with salt and salt substitute were similar. This is in accordance with Lian et al. (2002) who partially replaced $\mathrm{NaCl}$ with $\mathrm{KCl}$ in surimi gels. The $\mathrm{Cl}^{-}$is thought to be responsible for the effect of $\mathrm{NaCl}$ on the myofibrillar proteins because it interacts strongly with the positive charges on the protein, while $\mathrm{Na}^{+}$is only weakly bound (Puolanne \& Terrell, 1983; Asghar, Samejima, \& Yasui, 1985). The present study confirms this hypothesis that $\mathrm{Cl}^{-}$is the main contributor to gel formation since the substitution of $\mathrm{NaCl}$ with $\mathrm{KCl}$ did not significantly alter surimi gelation pattern (i.e., G'). Based on the nuclear magnetic resonance, Belton, Packer, \& Southon (1987) found that the $\mathrm{Cl}^{-}$causes repulsion of myofibrillar proteins regardless of the presence of cation. The rheological properties (Fig. 2) showed similar trends to the DSC thermograms (Fig. 1) confirming that the addition of salt or 
salt substitute increases protein unfolding, leading to greater denaturation and eventually to the development of a more elastic surimi gel.

\section{Fundamental texture properties of surimi gels}

The shear stress and strain at fracture determined with the torsion test are considered a fundamental test for texture properties because they provide objective texture measurements (Kim et al., 2005). Shear stress and strain of Alaska pollock surimi gels with different concentrations of salt and salt substitute are shown in Fig. 3. Alaska pollock surimi typically results in excellent gel texture. Therefore, grade A of this surimi was used in the present study to determine the effects of salt substitution on gel texture. Torsion shear stress and strain indicate strength and cohesiveness of surimi gels, respectively (Kim et al., 2005). Alaska pollock surimi gels with salt substitute had similar $(\mathrm{P}>0.05)$ strength and cohesiveness to the surimi gels with salt at equal molar concentrations. Addition of salt and salt substitute increased $(\mathrm{P}<0.05)$ gel strength approximately by two fold compared to the strength of surimi gels without salt or salt substitute. However, gel strength and cohesiveness decreased $(\mathrm{P}<0.05)$ for the highest concentration $(0.51 \mathrm{M})$ of both, salt and salt substitute. Therefore, based on the present study, the optimum level of salt or salt substitute for texture development of surimi seafood is $0.34 \mathrm{M}$. At this level, surimi gels made with salt or salt substitute had the highest, but similar $(\mathrm{P}>0.05)$ strength and cohesiveness. The torsion data also confirms the rheology (Fig. 2) and DSC (Fig. 1) trends. The addition of salt substitute results in similar texture of surimi seafood as salt, while reducing sodium content in final product. 


\section{Conclusions}

The effect of salt and salt substitute on protein endothermic transitions (thermal denaturation), rheological properties (protein gelation), and fundamental texture properties of Alaska pollock surimi were determined and compared. Salt and salt substitute shifted the onset of myosin transition to higher temperature and resulted in larger myosin peaks (i.e., transition enthalpy). Endothermic transitions showed similar trends to rheological properties. The elastic modulus (G’) increased when salt or salt substitute was added to surimi except the highest concentration of salt and salt substitute. Salt and salt substitute also induced the onset of protein gelation (i.e., as measured by significant increase of G') at lower temperature. Surimi gels with salt substitute and salt at equal molar concentrations had similar texture properties (shear stress and strain). Based on the present study, salt substitute can be used in the development of low sodium surimi seafood products without significant change in gelation and texture. Further studies are suggested to determine sensory quality and microbial storage stability. 


\section{References}

Asghar, A., Samejima, K., \& Yasui, T. (1985). Functionality of muscle proteins in gelation mechanisms of structured meat products. CRC Critical Review in Food Science and Nutrition, 22(1), 27-106.

Autio, K., Kiesvaara, M., \& Polvinen, K. (1989). Heat-induced gelation of minced rainbow trout (Salmo gairdneri): effect of pH, sodium chloride and setting. Journal of Food Science, 54(4), 805-808.

Belton, P.S., Packer, K.J., \& Southon, T.E. (1987). ${ }^{35} \mathrm{Cl}$ nuclear magnetic resonance studies of the interaction of chloride ions with meat in the presence of tripolyphosphate. Journal of the Science of Food and Agriculture, 41(3), 267-275.

Benjakul, S., Visessanguan, W., Ishizaki, S., \& Tanaka, M. (2001a). Differences in gelation characteristics of natural actomyosin from two species of bigeye snapper, Priacanthus tayenus and Priacanthus macracanthus. Journal of Food Science, 66(9), 1311-1318.

Benjakul, S., Visessanguan, W., \& Srivilai, C. (2001b). Gel properties of bigeye snapper (Priacanthus tayenus) surimi as affected by setting and porcine plasma proteins. Journal of Food Quality, 24(5), 453-471.

Chen, Y.C., \& Jaczynski, J. (2007a). Gelation of protein recovered from whole Antarctic krill (Euphausia superba) by isoelectric solubilization/precipitation as affected by functional additives. Journal of Agricultural and Food Chemistry, 55, 1814-1822.

Chen, Y.C., \& Jaczynski, J. (2007b). Protein recovery from rainbow trout (Oncorhynchus mykiss) processing by-products via isoelectric solubilization/precipitation and its gelation properties as affected by functional additives. Journal of Agricultural and Food Chemistry, 55, 9079-9088.

Centers for Disease Control and Prevention. (2009). Americans consume too much salt. Available from: http://www.cdc.gov/media/pressrel/2009/r090326.htm. Accessed July 7, 2011.

Dileep, A.O., Shamasundar, B.A., Binsi, P.K., Badii, F., \& Howell, N.K. (2005). Effect of ice storage on the physicochemical and dynamic viscoelastic properties of ribbonfish meat. Journal of Food Science, 70(9), E537-545.

Egelansdal, B., Martinsen, B., \& Autio, K. (1995). Rheological parameters as predictor of protein functionality: a model study using myofibrils of different fiber-type composition. Meat Science, 39(1), 97-111.

Fernandez-Martin, F., Fernandez, P., Carballo, J., \& Jimenez-Colmenero, F. (2000). DSC study on the influence of meat source, salt and fat levels, and processing parameters on batters pressurization. European Food Research and Technology, 211, 387-392. 
Ferry, J.D. (1980). Viscoelastic properties of polymers (3rd ed.). New York: John Wiley \& Sons.

Freud, R.J., \& Wilson, W.J. (1997). Design of experiments. San Diego (CA): Academic Press.

Gelabert, J., Gou P., Guerrero, L, \& Arnau, J. (2003). Effect of sodium chloride replacement on some characteristics of fermented sausages. Meat Science, 65(2), 833-839.

Geleijnse, J.M., Witteman, J.C., Bak, A.A., den Breeijen, J.H., \& Grobbee, D.E. (1994). Reduction in blood pressure with a low sodium, high potassium, high magnesium salt in older subjects with mild to moderate hypertension. British Medical Journal, 309, 436-440.

Hamann, D.D. (1992). Rheological studies of fish proteins. Pages 4-49 in International Conference and Industrial Exhibition on Food Hydrocolloids. Japanese Society of Food Hydrocolloids, Tokyo, Japan.

Hamann, D.D., \& MacDonald, G.A. (1992). Rheology and texture properties of surimi and surimi-based foods. In T.C. Lanier, \& C.M. Lee (Eds.), Surimi technology. New York: Marcel Dekker.

Jaczynski, J., \& Park, J.W. (2003). Physicochemical properties of surimi seafood as affected by electron beam and heat. Journal of Food Science, 68(5), 1626-1630.

Jaczynski, J., \& Park, J.W. (2004). Physicochemical changes in Alaska Pollock surimi and surimi gel as affected by electron beam. Journal of Food Science, 69, 53-57.

Kassis, N., Drake, S.R., Beamer, S.K., Matak, K.E., \& Jaczynski, J. (2010). Development of nutraceutical egg products with omega-3-rich oils. LWT - Food Science and Technology, 43(5), 777-783.

Kim, B.Y., \& Park, J.W. (2000). Rheology and texture properties of surimi gels. Food Science and Technology, 101, 267-324.

Kim, B.Y., Park, J.W., \& Yoon, W.B. (2005). Rheology and texture properties of surimi gels. In J.W. Park (Ed.), Surimi and Surimi Seafood (2nd ed). Boca Raton (FL): Taylor and Francis.

Lee, H.G., Lanier, T.C., \& Hamann, D.D. (1997). Chemically induced covalent crosslinks affect thermorheological profiles of fish protein gels. Journal of Food Science, 62(1), 29-32.

Lian, P.Z., Lee, C.M., \& Chung, K.H. (2002). Textural and physical properties of acid-induced and potassium-substituted low-sodium surimi gels. Journal of Food Science, 67(1), 109-112.

McGuire, M., \& Beerman, K.A. (2007). Nutritional sciences, From fundamentals to food. Belmont (CA): Thomson Learning.

Ni, S., Nozawa, H., \& Seki, N. (2001). Effect of pH on the gelation of walleye pollack surimi and carp actomyosin pastes. Fisheries Science, 67(5):920-927. 
Niwa, E. (1992). Chemistry of surimi gelation. In T.C. Lanier, \& C.M. Lee (Eds.), Surimi technology. New York: Marcel Dekker.

Park, J.W., \& Lanier, T.C. (1989). Scanning calorimetric behavior of tilapia myosin and actin due to processing of muscle and protein purification. Journal of Food Science, 54, 49-51.

Pedro, S., \& Nunes, M.L. (2007). Reducing salt in seafood products. In D. Kilcast, \& F. Angus (Eds.), Reducing salt in foods: Practical strategies. Cambridge: Woodhead Publishing.

Perez-Mateos, M., Boyd, L., \& Lanier, T. (2004). Stability of omega-3 fatty acids in fortified surimi seafoods during chilled storage. Journal of Agricultural and Food Chemistry, 52, 79447949.

Pietrowski, B.N., Tahergorabi, R., Matak, K.E., Tou, J.C., \& Jaczynski, J. (2011). Chemical properties of surimi seafood nutrified with $\omega-3$ rich oils. Food Chemistry, 129, 912-919.

Privalov, P.L., \& Khechinashvili, N.N. (1974). A thermodynamic approach to the problem of stabilization of globular protein structure: A calorimetric study. Journal of Molecular Biology, $86,665-684$.

Puolanne, E.J., \& Terrell, R.N. (1983). Effect of rigor state, level of salt and sodium tripolyphosphate on physical, chemical and sensory properties of frankfurter-type sausages. Journal of Food Science, 48(4), 1036-1038.

Riera, J.B., Martinez, M.R., Salcedo, R.C., Juncosa, G.M., \& Sellart, J.C. (1996). Process for producing a low sodium meat product. U.S. Patent and Trademark Office, patent number $5,534,279$.

Ruusunen, M., \& Puolanne, E. (2005). Reducing sodium intake from meat products. Meat Science, 70, 531-541.

SAS Institute (2002). SAS/STAT guide for personal computers, version 8.1. Cary (NC):SAS Institute.

Spink, C. H. (2008). Differential scanning calorimetry. Methods in Cellular Biology, 84, 115141.

Tahergorabi, R., Beamer, S.K., Matak, K.E., \& Jaczynski, J. (2011a). Effect of isoelectric solubilization/precipitation and titanium dioxide on whitening and texture of proteins recovered from dark chicken-meat processing by-products. LWT - Food Science and Technology, 44(4), 896-903.

Tahergorabi, R., Beamer, S.K., Matak, K.E., \& Jaczynski, J. (2011b). Physicochemical properties of surimi gels with salt substitute. LWT-Food Science and Technology. Under review. 
Taskaya, L., Chen, Y.C., \& Jaczynski, J. (2009). Functional properties of proteins recovered from whole gutted silver carp (Hypophthalmichthys molitrix) by isoelectric solubilization / precipitation. LWT - Food Science and Technology, 42(6), 1082-1089.

Taskaya, L., Chen, Y.C., \& Jaczynski, J. (2010). Color improvement by titanium dioxide and its effect on gelation and texture of proteins recovered from whole fish using isoelectric solubilization / precipitation. LWT - Food Science and Technology, 43(3), 401-408.

Wright, D.J., Leach, I.B., \& Wilding, P. (1977). Differential scanning calorimetric studies of muscle and its constituent proteins. Journal of the Science of Food and Agriculture, 28, 557-564.

Yongswatdigul, J., \& Park, J.W. (2004). Effects of alkali and acid solubilization on gelation characteristics of rockfish muscle proteins. Journal of Food Science, 69, 499-505.

Yoon, W.B., Kim, B.Y., \& Park, J.W. (1999). Rheological characteristics of fibrinogen-thrombin solution and its effects on surimi gels. Journal of Food Science, 64(2):291-294. 
Table 1. Final batter formulations. Batters with different levels of salt $(\mathrm{NaCl})$ and $\mathrm{KCl}$-based salt substitute were formulated to contain 78\% moisture and equal amount of surimi (protein + cryoprotectants), water, and water-based crab flavor by using inert filler, silicon dioxide $\left(\mathrm{SiO}_{2}\right)$. The three levels of addition of salt $(\mathrm{NaCl})$ and $\mathrm{KCl}$-based salt substitute were standardized based on molar concentration. The salt was $100 \% \mathrm{NaCl}$ and the salt substitute was $68 \% \mathrm{KCl}$; molecular weight $\left(\mathrm{M}_{\mathrm{w}}\right)$ of $\mathrm{NaCl}=58.5 \mathrm{~g}$ and $\mathrm{M}_{\mathrm{w}}$ of $\mathrm{KCl}$ $=74.5 \mathrm{~g}$. Batch size was $1000 \mathrm{~g}$.

\begin{tabular}{|c|c|c|c|c|c|c|c|c|}
\hline \multicolumn{2}{|c|}{ SALT (NaCl) } & \multicolumn{2}{|c|}{ KCl-BASED SALT SUBSTITUTE } & \multirow[b]{2}{*}{$\begin{array}{c}\text { Filler }-\mathrm{SiO}_{2} \\
\text { (g/1000 g) }\end{array}$} & \multirow[b]{2}{*}{$\begin{array}{l}\text { Surimi } \\
(\mathrm{g} / 1000 \mathrm{~g})\end{array}$} & \multirow[b]{2}{*}{$\begin{array}{c}\text { Water } \\
\text { (g/1000 g) }\end{array}$} & \multirow[b]{2}{*}{$\begin{array}{l}\text { Crab flavor } \\
\text { (g/1000 g) }\end{array}$} & \multirow[b]{2}{*}{$\begin{array}{c}\text { Batch weight } \\
\text { (g) }\end{array}$} \\
\hline $\begin{array}{c}\text { Molar } \\
\text { concentration }\end{array}$ & $\begin{array}{l}\text { Weight } \\
\text { (g/1000 g) }\end{array}$ & $\begin{array}{c}\text { Molar } \\
\text { concentration }\end{array}$ & $\begin{array}{l}\text { Weight } \\
\text { (g/1000 g) }\end{array}$ & & & & & \\
\hline 0.0 (control) & 0.0 (control) & 0.0 (control) & 0.0 (control) & 55.9 & 656.4 & 250.7 & 37.0 & 1000.0 \\
\hline $0.17 \mathrm{M}$ & 10.0 & 0.0 & 0.0 & 45.9 & 656.4 & 250.7 & 37.0 & 1000.0 \\
\hline $0.34 \mathrm{M}$ & 20.0 & 0.0 & 0.0 & 35.9 & 656.4 & 250.7 & 37.0 & 1000.0 \\
\hline $0.51 \mathrm{M}$ & 30.0 & 0.0 & 0.0 & 25.9 & 656.4 & 250.7 & 37.0 & 1000.0 \\
\hline 0.0 & 0.0 & $0.17 \mathrm{M}$ & 18.6 & 37.3 & 656.4 & 250.7 & 37.0 & 1000.0 \\
\hline 0.0 & 0.0 & $0.34 \mathrm{M}$ & 37.3 & 18.6 & 656.4 & 250.7 & 37.0 & 1000.0 \\
\hline 0.0 & 0.0 & $0.51 \mathrm{M}$ & 55.9 & 0.0 & 656.4 & 250.7 & 37.0 & 1000.0 \\
\hline
\end{tabular}


Table 2. The onset $\left(\mathrm{T}_{\text {onset }}\right)$ and maximum $\left(\mathrm{T}_{\max }\right)$ temperatures for endothermic transitions and net heat energy (enthalpy, $\Delta \mathrm{H}$ ) required for these transitions to occur in surimi pastes with $\mathrm{NaCl}$ and salt substitute. The $\mathrm{T}_{\text {onset }}, \mathrm{T}_{\max }$, and $\Delta \mathrm{H}$ were determined from differential scanning calorimetry (DSC) thermograms (Fig. 2).

\begin{tabular}{|c|ccc|}
\hline \multicolumn{1}{|c}{ Treatment } & $\mathrm{T}_{\text {onset }}\left({ }^{\circ} \mathrm{C}\right)$ & $\mathrm{T}_{\max }\left({ }^{\circ} \mathrm{C}\right)$ & $\Delta \mathrm{H}(\mathrm{J} / \mathrm{g})$ \\
\hline Control & 31.37 & 39.96 & 5.55 \\
\hline $0.17 \mathrm{M} \mathrm{NaCl}$ & 36.77 & 56.24 & 37.56 \\
$0.34 \mathrm{M} \mathrm{NaCl}$ & 38.71 & 49.92 & 18.88 \\
$0.51 \mathrm{M} \mathrm{NaCl}$ & 37.78 & 52.01 & 12.16 \\
\hline $0.17 \mathrm{M}$ salt substitute & 35.81 & 45.14 & 2.60 \\
$0.34 \mathrm{M}$ salt substitute & 31.12 & 48.76 & 13.77 \\
$0.51 \mathrm{M}$ salt substitute & 43.20 & 63.02 & 8.29 \\
\hline
\end{tabular}



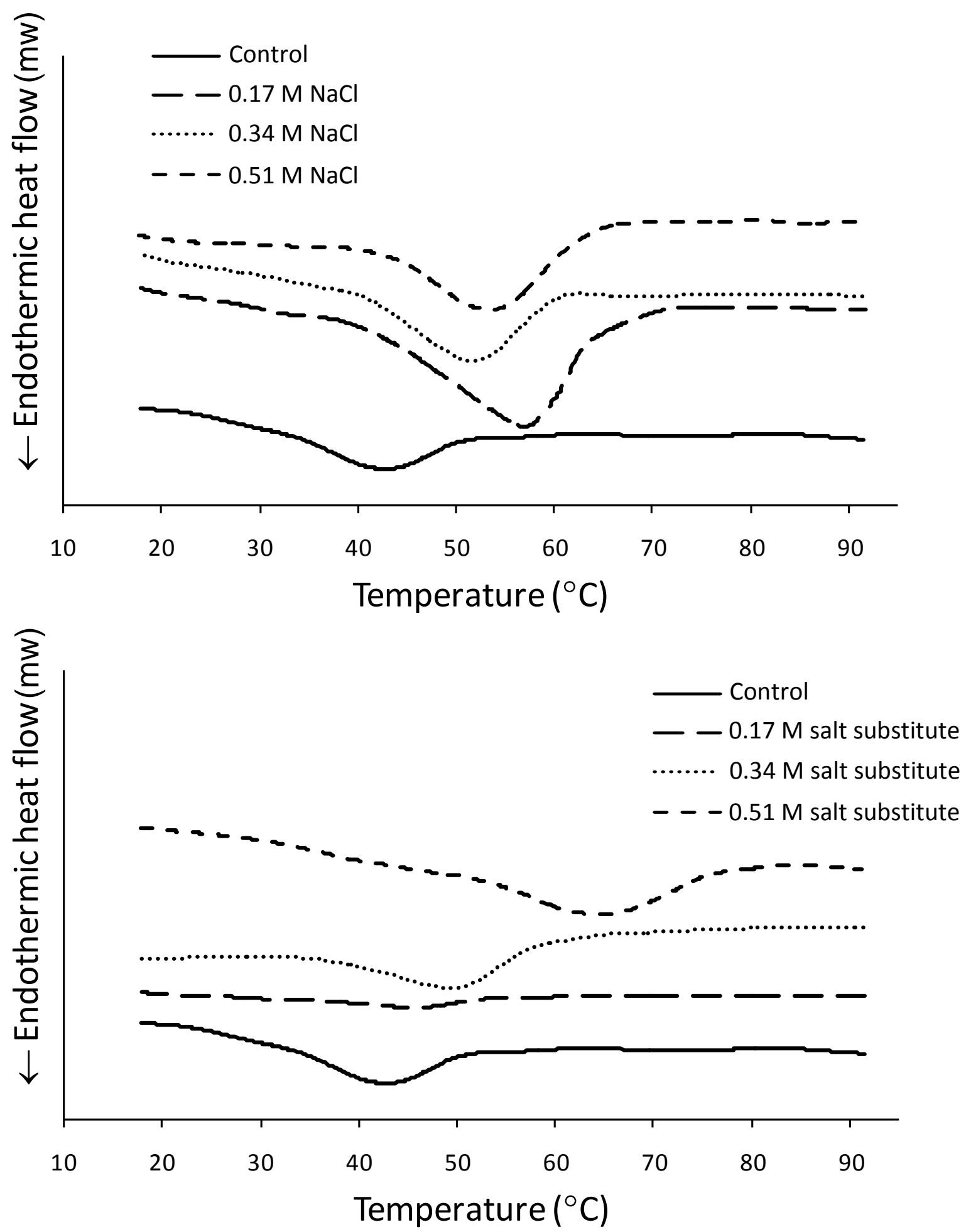

Figure 1. Differential scanning calorimetry (DSC) thermograms of surimi pastes with $\mathrm{NaCl}$ and salt substitute. 

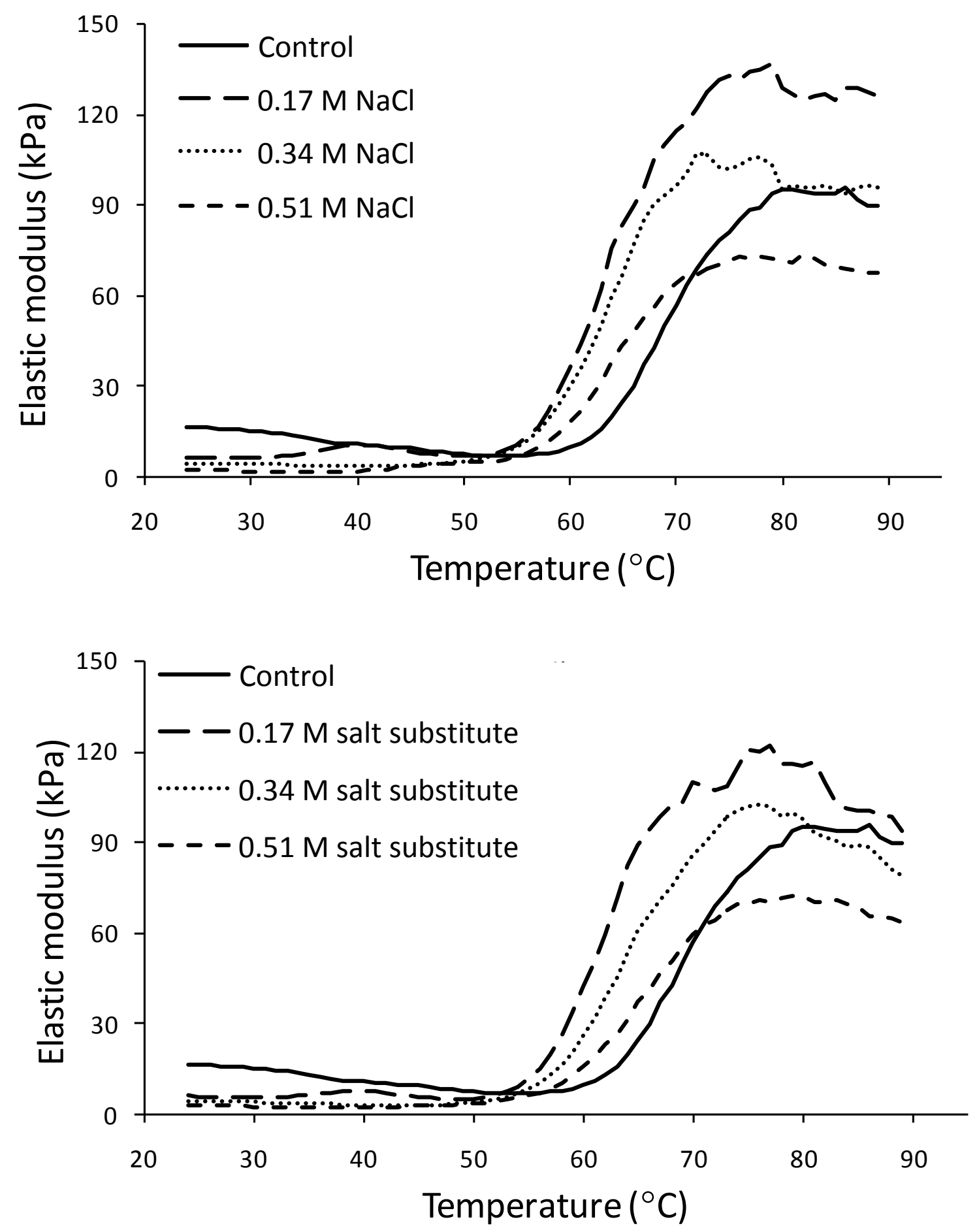

Figure 2. Average elastic modului (G') of surimi pastes with $\mathrm{NaCl}$ and salt substitute. 


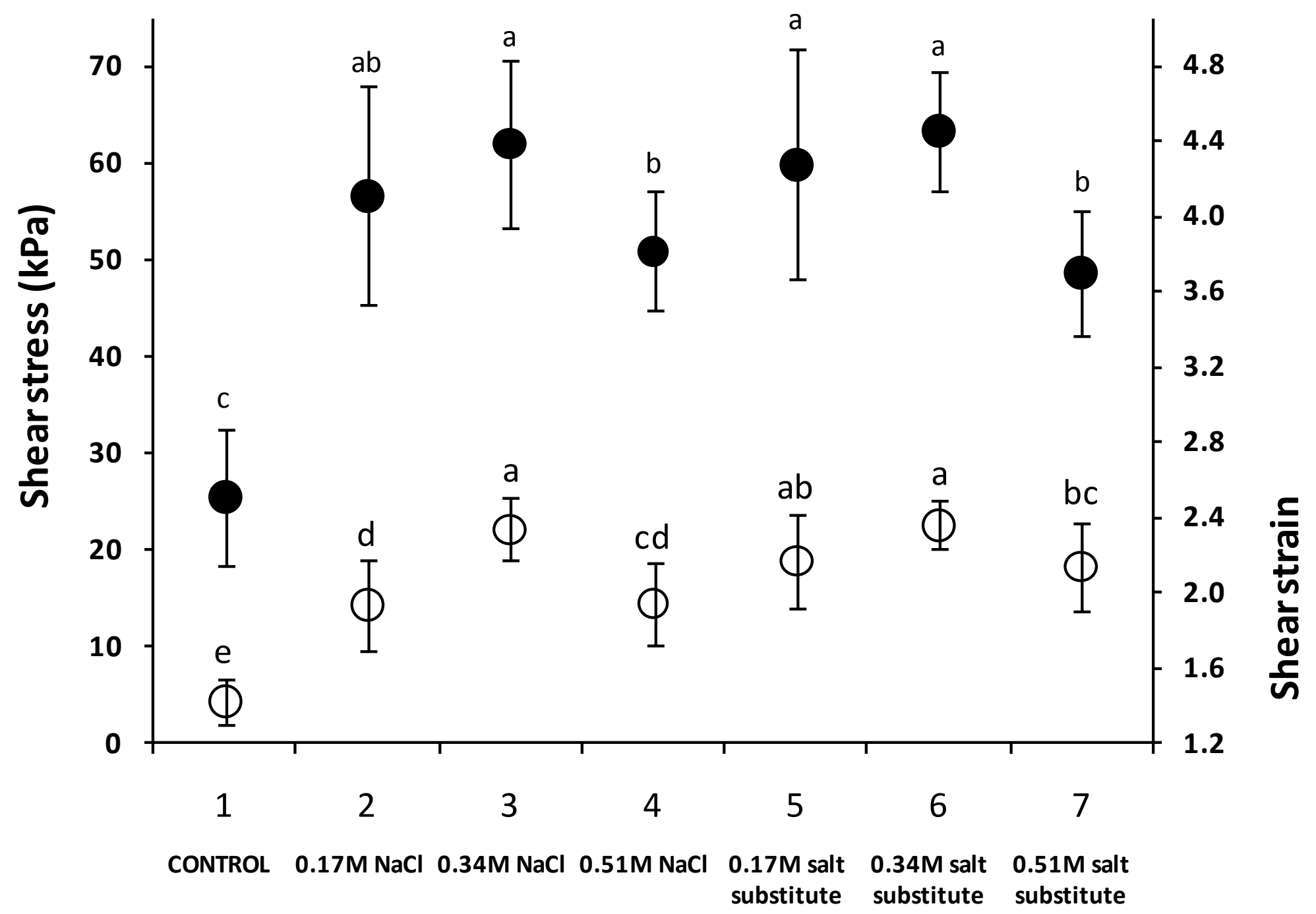

Figure 3. Effect of salt and salt substitute on torsion shear stress and strain at mechanical fracture of surimi gels $(\bullet-$ shear stress; $\circ-$ shear strain). Bars on data points indicate standard deviation (SD). Different letters on the top of SD bars indicate significant differences (Fisher's Least Significant Difference (LSD) test, $\mathrm{P}<0.05, \mathrm{n}=3$ ). 


\section{CHAPTER 4}

Development of functional fish product from isoelectrically recovered protein with $\omega-3$ rich oils and salt substitute

Tahergorabi R, Beamer S, Matak K, Jaczynski, J. (2012). Food Chemistry, To be submitted for publication. 


\begin{abstract}
Fish processing generates large quantities of by-products. There is a large potential for reducing the amount of discarded materials and produce value-added products for human consumption. On the other hand, Western diet is characterized as low in $\omega$-3 fatty acids (FAs) and high in $\omega-6$ FAs. Due to the cardioprotective effect of $\omega-3$ FAs there is an increasing demand to enhance diet with these oils. In the present study, trout protein isolate was enriched with $\omega-3$ FAs (flaxseed, algae, fish, krill and blend). The objectives of this study were to characterize effects of $\omega$-3 FAs incorporation on (1) FA profile and oxidation, (2) total volatile basic nitrogen (TVBN) and (3) texture of the nutritionally-enriched trout gels. Addition of flaxseed oil

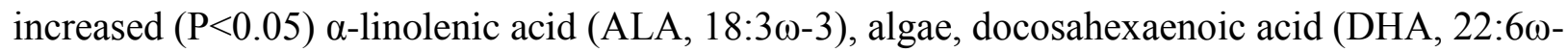

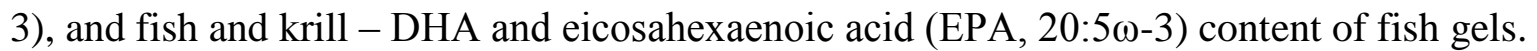
Atherogenic and thrombogenic values were lower $(\mathrm{P}<0.05)$ than those found in beef or chicken, indicating that trout gels enriched with PUFA rich oils can be considered healthful food in terms of the risk of cardiovascular diseases. Lipid oxidation in gels following cooking was minimal. TVBN contents were low. Texture analysis (torsion test) showed that addition of $\omega$-3 FAs-rich oils improve gel strength and cohesiveness.
\end{abstract}

Keywords: isoelectric solubilization/precipitation, fish processing by-products, fish fatty acid profile, flaxseed oil, algae oil, fish oil, krill oil, functional food products 


\section{Introduction}

Globally, fish provide 20 and $15 \%$ of the total dietary intake of animal protein for 1.5 and 3 billion people, respectively. In 2007, global consumption of fish was $17.1 \mathrm{~kg}$ per capita, accounting for $6.2 \%$ of all proteins consumed (FAO, 2008). A global decline in marine fish stocks has become a widely disputed and publicized issue. Freeman et al. (2006) estimated that the amount of large marine fish is $10 \%$ of their original stocks prior to global industrialization. It has also been stated that by mid- $21^{\text {st }}$ century most commercial fisheries may collapse (Mooney, Nichols, \& Elliott, 2002). These declines, when coupled with increasing human population necessitate a development of processing strategies to maximize the recovery of functional and nutritious fish muscle proteins from low-value/underutilized species and fish processing byproducts. The recovered proteins would be subsequently used in value-added seafood products destined for human consumption.

Isoelectric solubilization/precipitation (ISP) allows selective, $\mathrm{pH}$-induced water solubility of muscle proteins with concurrent separation of lipids and removal of materials not intended for human consumption such as bones, skin, scales, etc. Muscle protein isolates from fish have thus far been recovered using ISP in a batch mode at the laboratory-scale (Choi \& Park, 2002; Kim, Park, \& Choi, 2003; Kristinsson \& Hultin, 2003; Undeland, Kelleher, \& Hultin, 2002) and pilotscale (Mireles DeWitt, Nabors, \& Kleinholz, 2007). The ISP processing has been applied to beef and fish processing by-products (Mireles DeWitt, Gomez, \& James, 2002; Chen \& Jaczynski, 2007a; 2007b). Most recently, ISP has been used to recover a muscle protein isolate from chicken meat by-products (Tahergorabi, Beamer, Matak, \& Jaczynski, 2011a, b). The ISP processing allows high protein recovery yields, while significantly reducing fat content (Chen \& Jaczynski, 2007b; Taskaya, Chen, Beamer, \& Jaczynski, 2009b). Recovered protein isolates 
retain functional properties and nutritional value (Chen, Tou, \& Jaczynski, 2007, 2009; Gigliotti, Jaczynski, \& Tou, 2008; Nolsoe \& Undeland, 2009; Taskaya, Chen, \& Jaczynski, 2009a; Taskaya, Chen, Beamer, Tou, \& Jaczynski, 2009c). Due to extreme pH during ISP, this technology results in a non-thermal microbial reduction (Lansdowne, Beamer, Jaczynski, \& Matak, 2009a; Lansdowne, Beamer, Jaczynski, \& Matak, 2009b). Therefore, ISP offers several advantages over mechanical filleting and may be a useful technology to recover functional and nutritious protein isolates from whole gutted fish (i.e., without prior filleting) or fish processing by-products for subsequent application in value-added food products.

Western diet is characterized by the increased dietary intake of saturated fat, $\omega-6$ fatty acids ( $\omega-6$ FAs), and trans-FAs, as well as decreased intake of $\omega-3$ FAs. As a result, the ratio of $\omega$-6 FAs to $\omega$-3 FAs is at 15-20 to 1 , instead of the recommended 1 to 1 (Eaton \& Konner, 1985; Eaton, Konner, \& Shostak, 1988; Simopoulos, 1991, 1999a, b, c). Alpha-linolenic (ALA, 18:3w3), eicosapentaenoic (EPA, 20:5 $\omega-3$ polyunsaturated FAs ( $\omega$-3 PUFAs), while linoleic (LA, 18:2 $\omega-6)$ and arachidonic acids (AA, 20:4 $\omega-6$ ) are the main $\omega-6$ PUFAs in aquatic animals (Chen, Nguyen, Semmens, Beamer, \& Jaczynski, 2006). There is increasing interest in the fortification of food products with $\omega-3$ PUFAs because of their health benefits, especially the reduction of cardiovascular disease (CVD) (Nair, Leitch, Falconder, \& Garg, 1997). According to the American Heart Association, CVD has had an unquestioned status of the number one cause of death in the U.S. since 1921 (American Heath Association, 2009). In 2004, the Food and Drug Administration (FDA) approved a health claim for reduced risk of CVD for foods containing $\omega-3$ PUFAs, mainly EPA and DHA (FDA, 2004). This provided a marketing leverage for functional foods fortified with $\omega-3$ PUFAs and initiated a development of food products addressing the diet-driven CVD. 
Anderson and Ma (2009) provided an up-to-date and comprehensive review of health benefits specific for ALA, EPA, and DHA. Since the seafood products developed from the ISPrecovered fish protein isolate would be formulated products associated with aquatic sources, they are a logical vehicle for increasing the consumption of $\omega-3$ PUFAs; and therefore, addressing the diet-driven CVD without the need for dietary supplements in a pill or capsule form.

The overall objective of this study was to recover a fish protein isolate by ISP from whole gutted rainbow trout (bone-in, skin- and scale-on) as a model for fish processing by-products. The ISP-recovered isolate was subsequently used for the development of heat-gelled functional seafood product enhanced with $\omega$-3 PUFAs. Specific objectives were to determine (1) FA composition including indices of atherogenicity and thrombogenicity, (2) lipid oxidation, (3) protein degradation, and (3) fundamental texture properties of fish protein isolate gels enhanced with $\omega$-3 PUFAs-rich oils (flaxseed, fish, algae, krill, and blend (flaxseed:algae:fish, 8:1:1)).

\section{Materials and methods}

Sample preparation and recovery of fish protein isolate with isoelectric solubilization/precipitation

Whole gutted rainbow trout (bone-in, skin- and scale-on) were purchased from a local aquaculture farm. Whole gutted trout were used as a model for fish processing by-products. The fish were subjected to isoelectric solubilization/precipitation (ISP) to recover muscle protein isolate. A processing flowchart for the recovery of fish protein isolate and subsequent development of heat-set gels is shown in Figure 1. 
The fish were ground (meat grinder model 812 with $2.3 \mathrm{~mm}$ grinding plates, Biro, Marblehead, $\mathrm{OH})$ followed by homogenization with distilled and de-ionized water $\left(\mathrm{dd}_{2} \mathrm{O}\right)$ at 1:6 ratio (ground fish:water, w:v) using a laboratory homogenizer (PowerGen 700, Fisher Scientific, Fairlawn, NJ) set at speed five for five minutes. During the entire ISP processing, temperature was carefully controlled at $4^{\circ} \mathrm{C}$. The processing time did not exceed $60 \mathrm{~min}$. The homogenization/mixing was continued with the PowerGen homogenizer set at speed three during subsequent $\mathrm{pH}$ adjustment steps.

A $6 \mathrm{~L}$ of the homogenate was transferred to a beaker and the $\mathrm{pH}$ was adjusted to $11.50 \pm 0.05$ with 5 and $0.5 \mathrm{~mol} \mathrm{~L}^{-1} \mathrm{NaOH}$ (Tahergorabi et al. 2011a; Chen \& Jaczynski, 2007a, b; Taskaya, Chen, Beamer, \& Jaczynski, 2009a). The 5 and $0.5 \mathrm{~mol} \mathrm{~L}^{-1}$ reagents were used for crude and fine $\mathrm{pH}$ adjustments, respectively, during both protein solubilization and subsequent precipitation $(\mathrm{pH}=5.5)$ (see below). Once the desired $\mathrm{pH}$ was obtained, the solubilization reaction was allowed to take place for $10 \mathrm{~min}$, followed by centrifugation at $10,000 \mathrm{x} g$ and $4^{\circ} \mathrm{C}$ for 10 min using a laboratory batch centrifuge (Sorvall Evolution RC Refrigerated Superspeed centrifuge equipped with Sorvall Fiber Lite rotor SLC-6000, Sorvall Centrifuges, Asheville, NC). The centrifugation resulted in three layers: top - fish oil, middle - fish muscle protein solution, and bottom - insolubles (bones, skin, insoluble proteins, membrane lipids, etc.).

The fish muscle protein solution was collected and its $\mathrm{pH}$ was adjusted to $5.50 \pm 0.05$ by 5 and $0.5 \mathrm{~mol} \mathrm{~L}^{-1} \mathrm{HCl}$ to precipitate the proteins. Once the desired $\mathrm{pH}$ was obtained, the precipitation reaction was allowed to take place for $10 \mathrm{~min}$. The solution with precipitated proteins was de-watered by centrifugation as above. The centrifugation resulted in two layers: top - process water, and bottom - precipitated and de-watered fish proteins isolate. The precipitated and de-watered fish protein isolate was collected. The final moisture of the isolate 
was adjusted to $82 \mathrm{~g} / 100 \mathrm{~g}$ by manual squeezing of the isolate wrapped in a cheese cloth. The isolate was used in the preparation of fish protein isolate paste.

\section{Preparation of fish protein isolate paste}

Fish protein isolate pastes were made using the procedure described by Jaczynski \& Park (2004). The ISP-recovered protein isolates were chopped in a universal food processor (Model UMC5, Stephan Machinery Corp., Columbus, OH) at low speed for 1 min. A fish protein paste was obtained by extracting myofibrillar proteins in the fish protein isolate with $0.34 \mathrm{M}$ of $\mathrm{KCl}-$ based salt substitute (AlsoSalt@ sodium-free salt substitute, AlsoSalt, Maple Valley, WA) and chopping at low speed for $0.5 \mathrm{~min}$ in the universal food processor. This level of salt substitute was found optimal and similar to salt $(\mathrm{NaCl})$ in terms of protein gelation and endothermal transitions as well as texture and color in heat-set fish protein gels (Tahergorabi \& Jaczynski, 2012; Tahergorabi, Beamer, Matak, \& Jaczynski, 2011c). The concentration of $0.34 \mathrm{M}$ of the salt substitute was equivalent to $2 \mathrm{~g}$ of $\mathrm{NaCl}$ per $100 \mathrm{~g}$ of the fish protein isolate. The salt substitute contained $68 \mathrm{~g}$ of $\mathrm{KCl}$ per $100 \mathrm{~g}$ of the salt substitute and L-lysine monohydrochloride and calcium stearate. According to the manufacturer, the patented L-lysine derivative masks the metallic-bitter aftertaste of $\mathrm{KCl}$.

Final moisture content of the fish protein isolate paste was adjusted to $68 \mathrm{~g} / 100 \mathrm{~g}$ by adding functional additives at the following final concentrations (w:w): $10 \mathrm{~g} / 100 \mathrm{~g}$ of a $\omega-3$ PUFAs-rich oil (see below), 3.7 g/100 g crab flavor (F-11019, Activ International, Mitry-Mory Cedex, France), 2 g/100 g of potato starch (PS) (Penbind 1000 modified potato starch, Penford Food Ingredients Corp., Centennial, CO), 0.5 g/100 g of microbial transglutaminase (MTGase) 
(Activa RM, Ajinomoto USA Inc., Teaneck, NJ), and $0.3 \mathrm{~g} / 100 \mathrm{~g}$ of polyphosphate (PP) (Kena FP-28, Innophos, Cranbury, NJ). The above levels of functional additives were found in previous studies as optimal for gelation of ISP-recovered fish protein isolates and consequently physicochemical properties of heat-set gels as well as closely resembling commercial surimibased seafood products (Perez-Mateos, Boyd, \& Lanier, 2004; Taskaya et al., 2009 a, b; Taskaya et al., 2010; Chen \& Jaczynski, 2007b). A $0.5 \mathrm{~g} / 100 \mathrm{~g}$ of titanium dioxide $\left(\mathrm{TiO}_{2}\right)$ [Titanium (IV) oxide, Sigma-Aldrich, Inc., St. Louis, MO] was also added to the paste (Taskaya et al., 2010; Tahergorabi et al., 2011a). $\mathrm{TiO}_{2}$ is commonly added up to $1 \mathrm{~g} / 100 \mathrm{~g}$ as a whitening agent in food products. The PS, MTGase, $\mathrm{TiO}_{2}$, and PP were in a dry powder form. The crab flavor was a water-soluble liquid. The $\omega-3$ PUFAs-rich oils (see below) were added at $10 \mathrm{~g} / 100 \mathrm{~g}$ by replacing ice/water (1:1) that is normally added to a fish protein-based paste such as surimi paste (Perez-Mateos et al., 2004; Park, 2005). One treatment with all of the additives except the oil was used as a control paste. The final moisture content of the control paste was adjusted to 78 $\mathrm{g} / 100 \mathrm{~g}$ by adding ice/water to the paste (Perez-Mateos et al., 2004; Park, 2005). To mix all of the ingredients with the fish protein isolate paste, chopping was applied at low speed for $1 \mathrm{~min}$. Addition of $\mathrm{TiO}_{2}$ to a protein paste results in poor quality of heat-set gel due to the $\mathrm{pH}$ lowering effect of $\mathrm{TiO}_{2}$ (Park, 2005). Therefore, the final $\mathrm{pH}$ of the paste in the present study was adjusted to 7.20 \pm 0.05 (Tahergorabi et al. 2011a; Taskaya et al., 2010). Additional chopping was performed at high speed under vacuum $(0.5 \mathrm{bar})$ for the last $3 \mathrm{~min}$. The paste temperature was controlled between $1-4^{\circ} \mathrm{C}$ during chopping. The fish protein isolate pastes were prepared in $1 \mathrm{~kg}$ batches.

The following $\omega$-3 PUFAs-rich oils were added during preparation of fish protein isolate pastes: 
1) Flaxseed oil was obtained from Jedwards International, Inc. (Quincy, MA).

2) Fish oil (Omega Pure 8042TE) was obtained from Omega Pure (Reedsville, VA).

3) Algae oil (DHAS) was obtained from Martek Biosciences (Columbia, MD).

4) Krill oil (4225F) was obtained from Enzymotec USA, Inc. (Springfield, NJ).

5) Blend (Flaxseed:Algae:Fish, 8:1:1)

The added oils are good sources of $\omega-3$ PUFAs and this is why they were selected in the present study (Pietrowski, Tahergorabi, Matak, Tou, \& Jaczynski, 2011; Kassis, Gigliotti, Beamer, Tou, \& Jaczynski, 2011; Kassis, Beamer, Matak, Tou, \& Jaczynski, 2010). Anderson and Ma (2009) provided an up-to-date and comprehensive review of health benefits specific for ALA and DHA. When oil is homogenized with a comminuted protein-based paste, it results in light scattering. Therefore, it improves whiteness of heat-set gels (Park, 2005). This is why, besides nutraceutical benefits, $10 \mathrm{~g} / 100 \mathrm{~g}$ of $\omega$-3 PUFAs-rich oil was added to the fish protein isolate paste in the present study. Fish protein isolate pastes prepared in this manner were used to develop heat-set gels.

Preparation of fish protein isolate gels

Fish protein isolate paste was stuffed into stainless steel tubes $($ length $=17.5 \mathrm{~cm}$, internal diameter $=1.9 \mathrm{~cm}$ ) with screw end caps for determination of fatty acid (FA) composition including indices of atherogenicity and thrombogenicity, lipid oxidation, and protein degradation. To determine fundamental texture properties with torsion test, the paste was stuffed into hour-glass pre-molded stainless steel torsion tubes $($ length $=17.5 \mathrm{~cm}$, end diameter $=1.9$ $\mathrm{cm}$, midsection diameter $=1.0 \mathrm{~cm}$ ) with screw end caps. Since the fish protein isolate pastes 
were prepared with MTGase, the tubes were incubated at $4^{\circ} \mathrm{C}$ for $24 \mathrm{~h}$ to allow for the formation of non-disulfide covalent $\varepsilon$-( $\gamma$-glutamyl)-lysine cross-links or the "suwari" effect. Following incubation, the tubes were heated in a water bath at $90^{\circ} \mathrm{C}$ for $15 \mathrm{~min}$. Tubes were immediately chilled in ice slush and the fish protein isolate gels were removed for analysis.

Fatty acid composition of the heat-set fish protein isolate gels

The fatty acid (FA) composition was determined by extracting lipids with acid hydrolysis into ether followed by their methylation to fatty acid methyl esters (FAMEs) (Chen, Nguyen, Semmens, Beamer, \& Jaczynski, 2007; 2008a). The FAMEs were quantitatively measured using a capillary gas-liquid chromatograph (GLC) (Model 7890A equipped with a 7683B series injector, Agilent Technologies, Santa Clara, CA) against an internal standard (C19:1). Helium was used as carrier gas at $0.75 \mathrm{ml} / \mathrm{min}$ flow rate and a 200:1 as split ratio. The initial temperature of $100^{\circ} \mathrm{C}$ was held for 4 min and then increased to the final temperature of $240^{\circ} \mathrm{C}$ at a heating rate of $3^{\circ} \mathrm{C} / \mathrm{min}$. The final temperature was held for $15 \mathrm{~min}$. The injector and detector temperatures were 225 and $285^{\circ} \mathrm{C}$, respectively. The data are reported as mean values ( \pm standard deviation) of at least three replicates and the mean values are expressed as percent of a fatty acid in total fatty acids.

Indices of atherogenicity and thrombogenicity

Based on the FA composition of heat-set fish protein isolate gels, the indices of atherogenicity (IA) and thromogenicity (IT) were calculated. The IA relates main saturated fatty 
acids (SFAs) to unsaturated fatty acids (UFAs). SFAs favor adhesion of lipids to cells of the immunological and circulatory system; and therefore, are considered pro-atherogenic. UFAs inhibit the aggregation of plaques, thereby reduce the risk of CVD; and therefore, are considered anti-atherogenic (Ulbritch \& Southgate, 1991; Senso, Suarez, Ruiz-Cara, \& Garcia-Gallego, 2007). The following equation was used to calculate the IA:

$$
I A=\frac{(4 \times C 14: 0)+C 16: 0+C 18: 0}{\sum M U F A+\sum \omega-6 P U F A+\sum \omega-3 P U F A}
$$

The IT indicates the tendency to form clots in blood vessels. The IT relates pro-thrombogenic (SFAs) to anti-thrombogenic FAs (Mono-UFAs, $\omega$-6 PUFAs, and $\omega$-3 PUFAs) (Ulbritch \& Southgate, 1991; Senso et al., 2007). The following equation was used to calculate the IT:

$$
I T=\frac{C 14: 0+C 16: 0+C 18: 0}{(0.5 \times M U F A)+(0.5 \times \omega-6 P U F A)+(3 \times \omega-3 P U F A)+\frac{\omega-3 P U F A}{\omega-6 P U F A}}
$$

Lipid oxidation of heat-set fish protein isolate gels

Oxidative rancidity of gel samples was measured by a 2- thiobarbituric acid reactive substances (TBARS) assay of malondialdehyde (MDA) as previously described (Chen et al., 2008; Jaczynski \& Park, 2003b). The absorbance was measured at $535 \mathrm{~nm}$ using an UV/Vis spectrophotometer (model DU530, Beckman Instruments, Fullerton, CA). The TBARS values were calculated using molar absorptivity of MDA $\left(156,000 \mathrm{M}^{-1} \mathrm{~cm}^{-1}\right)$ at $535 \mathrm{~nm}$. The TBARS 
values are reported as mean values ( \pm standard deviation) of at least three replicates and the mean values are expressed as mg of MDA per $\mathrm{kg}$ of heat-set gel sample.

Protein degradation of heat-set fish protein isolate gels

Protein degradation of gel samples was determined with total volatile basic nitrogen (TVBN) assay. A $10 \mathrm{~g}$ sample of fish protein gel was homogenized with $200 \mathrm{ml}$ of $\mathrm{dd}_{2} \mathrm{O}$ and $2 \mathrm{~g}$ of magnesium oxide and one drop of silicone were added to prevent foaming. The mixture was distilled in a Micro-Kjeldahl unit and the distillate was titrated with $0.1 \mathrm{~N}$ hydrochloric acid. The TVBN values are reported as mean values ( \pm standard deviation) of at least three replicates and the mean values are expressed as mg of nitrogen per $100 \mathrm{~g}$ of heat-set gel sample.

Fundamental texture properties of heat-set fish protein isolate gels

Torsion test of heat-set trout gels was performed according to Tahergorabi, Beamer, Matak, \& Jaczynski (2011a). At least seven hour-glass-shaped gels (length $=2.54 \mathrm{~cm}$, end diameter $=1.9 \mathrm{~cm}$, and midsection diameter $=1.0 \mathrm{~cm}$ ) per treatment were glued to plastic discs and subjected to torsional shear using a Hamman Gelometer (Gel Consultant, Raleigh, NC) set at $2.5 \mathrm{rpm}$. Shear stress and shear strain at mechanical fracture are fundamental texture properties indicating gel strength and gel cohesiveness, respectively (Kim, Park, \& Yoon, 2005).

\section{Statistics}


The experiments were independently triplicated $(n=3)$. In each triplicate at least three measurements were performed for FA composition, three for TBARS, three for TVBN, and eight for torsion test. Data were subjected to one-way analysis of variance (ANOVA). A significant difference was determined at 0.05 probability level and differences between treatments were tested using the Fisher's Least Significant Difference (LSD) test (Freud \& Wilson, 1997). All statistical analyses of data were performed using SAS (SAS, 2002). The data are reported as mean values \pm standard deviation $(\mathrm{SD})$.

\section{Results and Discussion}

Fatty acid composition of the heat-set fish protein isolate gels

Fatty acid content of the control and the enriched gels with PUFA rich oils presented on percent basis in Fig.2. The ratio of PUFA to SFA and $\omega-6 / \omega-3$ was calculated, and results were statistically $(\mathrm{P}<0.05)$ analyzed and tabulated in Table 1.

Fish and fish derivates consumption are recommended by health authorities, not only for their high-quality protein content, but also for being a source of fatty acids considered highly beneficial for human health ( $\omega-3$ and $\omega-6)$. Linolenic acid (ALA, 18:3 $\omega-3)$, eicosapentaenoic

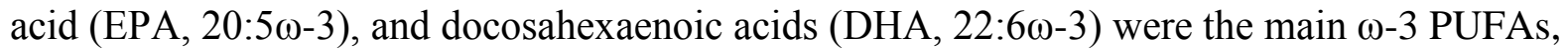

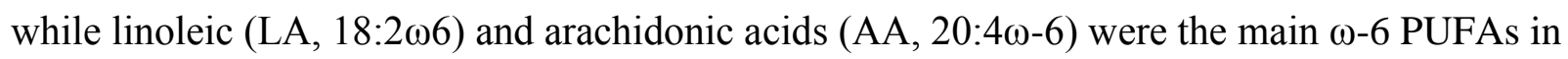
whole gutted trout. Chen et al (2006) reported fatty acid (FA) content of farm-raised trout to be ALA 2.6, EPA 4.7, DHA, 16.7, LA 12.5, AA 0.6, total $\omega-3$ PUFAs 24.7 , and $\omega-6$ PUFAs $14.3 \%$ and $\omega-3 / \omega-6$ ratio 1.7 , although the content can vary in farm-raised trout fillets depending on the 
feed. These data are in accordance with our data for the control samples without any PUFA rich oil addition. Chen et al (2007) reported that the $\mathrm{pH}$ treatment during solubilization of the protein in trout processing by-products did not $(\mathrm{P}>0.05)$ affect the composition of $\omega-3$ and $\omega-6$ PUFAs and consequently, the $\omega-3 / \omega-6$ ratio in the recovered trout lipids.

Trout gels enriched with $\omega-3$ rich oils contained significantly more $(\mathrm{P}<0.05)$ total $\omega-3$ PUFA (flaxseed-50.95\%, blend- 48.84\%, krill-45.68\%, algae-42.77\%, fish-34.36\%) than control (no oil- 19.78) (Fig 2B). Flaxseed oil also called "linseed oil" is a yellowish oil obtained from the dried ripe seeds of the flax plant and is a rich source of the $\omega-3$ fatty acid ALA (51.9- 55.2\%) (Berglund, 2002; Ansorena and Astiasaran, 2004). Flaxseed oil is edible oil, but because of its strong flavor and odor, it is only a minor constituent of human nutrition, although it is marketed as nutritional supplement. Thus, the experimental trout gels developed with flaxseed oil and blend (8\% flaxseed oil) contained the highest $(\mathrm{P}<0.05)$ amount of ALA $(48.95 \%$, and 39.45\%, respectively) compared to other trout gels (algae-0.54\%, krill-1.15\%, fish- $2.45 \%$ ). Pietrowski et al. 2011 also reported that surimi gels enriched with 10\% flaxseed oil contained 44.4\% ALA which is in agreement with our results. Singh et al. 2011 also showed that chicken meat patties enhanced with $3 \%$ of flaxseed oil contained significantly higher $(\mathrm{P}<0.05)$ ALA $(18.5 \%)$ compared to control (no oil) samples (5.9\%). Trout gels developed with fish and krill oil had the greatest $(\mathrm{P}<0.05)$ level of EPA $(16.18 \%, 24.23 \%$, respectively), whereas all other gels contained EPA less than $3 \%$.

Commercial algal oils contain DHA as their major $\omega-3$ fatty acid (Newton, 1998). DHA is known to be crucial for proper nervous system and vision development (Chapman, Regenstein, 1997). Both DHA and EPA are believed to have several health benefits for cardiovascular disease, immune disorders, inflammation, allergies, and diabetes. As expected, DHA 
concentrations in the trout gel increased upon addition of algal oil (Fig. 2A). Ward and Singh (2005) reported that one should consume 90-105 g/day of rainbow trout in the diet to provide $1 \mathrm{~g}$ EPA and DHA per day but in this study a serving size of trout gel enriched with algae or fish oil provide more than this amount. It is important to mention that the DHA content of krill oil is similar to that of shrimp and fish. This is not surprising given that krill feed on marine phytoplankton such as single-cell microalgae, which synthesize large amount of DHA. However, most of the fatty acids in fish are incorporated into triglycerides, whereas $65 \%$ of the fatty acids in crustaceans are incorporated into phospholipids. The phospholipids and triglycerides require different digestive enzymes and therefore, there may be differences in bioavability and tissue accretion of DHA (Pietrowski et al. 2011). Trout gels developed with flaxseed oil had the highest $(\mathrm{P}<0.05)$ content of LA $(16.45 \%)$, followed by control and blend $(10.30 \%, 13.73 \%$, respectively). Consequently, flaxseed, control and blend oils resulted in the highest $(\mathrm{P}<0.05)$ content of $\omega-6$ PUFA (Fig. 2B).

As a result of the difference between FA compositions in trout gels, the ratio of $\omega-6 / \omega-3$ between gels although were significantly different $(\mathrm{P}<0.05)$ but numerically these differences were negligible. Today, in western diets, the ratio of $\omega-6 / \omega-3$ fatty acids ranges from 10 to $20: 1$ instead of the traditional range of 1 to 2:1 (Simopulous, 1999b). This author also reported that a high intake of $\omega-6$ fatty acids shifts the physiologic state to one that is prothrombotic and proaggregatory, characterized by increases in blood viscosity, vasospasm, and vasoconstriction and decreases in bleeding time; whereas $\omega$-3 fatty acids have anti-inflammatory, antithrombotic, antiarrhythmic, hypolidemic, and vasodilatory properties. The UFA/SFA ratio was the highest $(\mathrm{P}<0.05)$ for gels with flaxseed oil and the lowest for gels with fish oil. 


\section{Indices of atherogenicity and thrombogenicity}

In our study two distinct indexes were investigated: 1) Index of atherogenicity (IA); and 2) Index of thrombogenicity (IT). These indexes take into account the different effects that single fatty acid might have on human health and in particular on the probability of increasing the incidence of pathogenic phenomena, such as atheroma and/or thrombus formation(Cahu, Salen, \& de Lorgeril, 2004; Ulbricht and Southgate, 1991). IA and IT were calculated as 0.62 and 0.41 (Table 1) for control (no oil). Valfre', Caprino \& Turchini, (2003) also reported IA and IT values of 0.57 and 0.37 for farm-raised rainbow trout respectively. For the PUFA enriched gels, flaxseed had the lowest values for IA and TI ( 0.11 and 0.05 respectively) followed by blend. These values are lower than those found in beef or chicken, indicating that trout gels enriched with PUFA rich oils can be considered healthful food in terms of the risk of cardiovascular diseases (Ulbricht and Southgate, 1991).

\section{Lipid oxidation of heat-set fish protein isolate gels}

Owing to the unsaturated nature of $\omega-3$ fatty acids they are highly susceptible to lipid oxidation, which can lead to flavor and color deterioration and loss of endogenous antioxidants. In the case of severe lipid oxidation, the content of $\omega-3$ may even decrease. Oxidative deterioration of fish may not only affect the lipids as the proteins are also susceptible to oxidation (Undeland et al. 2008). Rancidity in fishery products as a result of autooxidation is measured in terms of the content of malonaldehyde, the principal compound in oxidized lipids (Hedges, 2002; Hyldig, \& Nielsen, 2001; Tarladgis, et al. 1960). The 2-thiobarbituric acid 
reactive substances (TBARS) test is one of the most commonly used methods to determine rancidity in fishery products.

Fig. 3 shows the result of TBARS analysis of the cooked trout gels. Gels developed with krill oil were the most $(\mathrm{P}<0.05)$ susceptible to oxidation. Trout gels with krill oil contained a high level of $\omega$-3 PUFA as DHA and EPA in a phospholipid form, which likely makes krill oil more prone to oxidation than other $\omega-3$ rich trout gels. Gels with flaxseed, algae, and blend oils had TBARS values lower $(\mathrm{P}<0.05)$ than krill oil, but higher $(\mathrm{P}<0.05)$ than trout gels with no oil or fish oil. This is probably due to the increased content of $\omega-3$ PUFA in these oils. Trout gel with no oil (i.e. control) had the lowest $(\mathrm{P}<0.05)$ TBARS value, which is likely due to the fact this sample had the lowest content of $\omega-3$ PUFA compared to other $\omega-3$ enhanced trout gels (Fig.1).

Ke et al. (1984) proposed that TBARS values for seafood products below $0.58 \mathrm{mg} / \mathrm{kg}$ were perceived as not rancid; $0.58-1.51 \mathrm{mg} / \mathrm{kg}$ slightly rancid, but acceptable; and above 1.51 $\mathrm{mg} / \mathrm{kg}$ were perceived as rancid. Using this correlation, all the experimental gels (i.e. flaxseed, algae, fish, krill and blend oil as well as gels with no oil) $[0.82-1.5 \mathrm{mg} / \mathrm{kg}]$ would be perceived as slightly rancid, but acceptable. These results are in agreement with Pietrowski et al. 2011 who studied lipid oxidation in surimi gels enhanced with PUFA rich-oils.

Protein degradation of heat-set fish protein isolate gels

TVBN content of trout gels was measured and depicted in Fig. 4. TVBN content of trout gel with no oil was $4.31 \mathrm{mg} \mathrm{N} / 100 \mathrm{~g}$, whereas trout gels enriched with PUFA rich oils had higher TVBN content (max:7.63 mg N/ $100 \mathrm{~g}$ ) for flaxseed oil samples and there were no significant 
difference between trout gels with PUFA rich oils. Benjakul et al. 2009 also reported similar results for the mackerel mince and corresponding surimi for the initial day of storage. They concluded that TVBN content could be reduced markedly by the alkaline saline washing process. The formation of TVBN is generally associated with the growth of microorganisms and can be used as an indicator of spoilage (Benjakul, Visessanguan, Riebroy, Ishizaki, \& Tanaka, 2002).Generally; TVBN consists mainly of trimethylamine (TMA) and ammonia, which are produced by both microbial and endogenous enzymes. A number of specific spoilage bacteria such as Shewanella putrefaciens, Photobacterium phosphoreum, Vibrionaceae, and so on typically use trimethylamine oxide (TMAO) as an electron acceptor in anaerobic respiration, resulting in off-odor and off-flavor due to the formation of TMA (Gram and Huss 1996). This might be true for basic isoelectric solubilization/ precipitation which has mild pasteurization effect (Lansdowne, 2009a). TVBN content of $30 \mathrm{mg} \mathrm{N} / 100 \mathrm{~g}$ is generally regarded as the fish acceptability limit (Sikorski et al. 1990). For all the trout gels, TVBN content was lower than the limiting level.

Fundamental texture properties of heat-set fish protein isolate gels

A torsion test has been proposed as an objective method to measure the mechanical properties of surimi gels, which could be applied to other gelling foods. This method allows the determination of shear stress and shearing strain at failure. Shear stress measures gel strength and correlates well with sensory hardness, texture profile analysis (TPA) hardness, and TPA fracturability. Shear strain measures the gel deformability and correlates well with cohesiveness and springiness (TPA) [Hamman \& Lanier, 1987; Kim, Hamman, Lanier, \& Wu, 1986]. 
Shear stress and shear strain of heat-set trout gels with and without addition of $\omega-3$ PUFA-rich oil is shown in Fig. 2. These results revealed that $\omega-3$ PUFA-rich oil addition within the ranges tested in the present study significantly $(\mathrm{P}<0.05)$ improved these textural parameters (Fig. 2). Xiong (1992) and Foegeding, Xiong, and Brekke (1991) demonstrated that strength of gel made with myofibrillar proteins improves when fat is added. It has been previously reported that fine fat globules may behave as co-polymers filling the voids within the gel matrix; and thus, resulting in reinforcement of the composite gel (Ziegler \& Foegeding, 1990). Lee and Abdollahi (1981) suggested that the addition of oil/fat to fish protein gels reduces brittleness; and minimizes textural variations resulting from cooking. Wu et al. (2009) found that gel strength increases with the concentration of added lipids; however, with the addition of $10 \mathrm{~g} / 100 \mathrm{~g}$ of oil, there were no differences $(\mathrm{P}>0.05)$, which is in contrast with our results. This might be due to different species used in these two studies. However, addition of krill oil resulted in the lowest shear stress and shear strain values. Pietrowski et al. 2011 reported that gels with krill oil had slightly poorer hardness, cohesiveness and springiness which correlate with shear stress and shear strain respectively. This might be due to the inherent properties of krill oil and its propensity for oxidation. A surimi gel with a shear strain value higher than 2.2 is considered high quality and can be used for producing crab or shrimp analogues. Surimi gels with strain values lower than 1.8 are considered low quality (Hamman \& Lanier, 1987; Kim, Hamman, Lanier, \& $\mathrm{Wu}, 1986)$. Based on this correlation all the trout gels enhanced with PUFA rich oils are considered as high quality gels.

\section{Conclusions}


Addition of $\omega$-3 PUFAs rich oils (flaxseed, algae, fish, krill and blend) enhanced nutritional properties of trout protein isolates. The trout gels had a higher content of $\omega-3$ PUFAs, in particular ALA, EPA and DHA while the texture properties were improved and lipid oxidation was in acceptable range. Incorporation of PUFA rich oils into rainbow trout protein isolate could produce a functional food product which mimics natural fish products. 


\section{References}

Anderson, B. M., \& Ma, D. W. L. (2009). Are all n-3 polyunsaturated fatty acids created equal? Lipids in Health and Disease, 8, 33.

Ansorena, D., \& Astiasaran, I. (2004).The use of linseed improves nutritional quality of lipid fraction of dry fermented sausages. Food Chemistry, 87, 69-74.

Balange, A.K., Benjakul, S., \& Maqsood, S. (2009). Gel strengthening effect of wood extract on surimi produced from mackerel stored in ice. Journal of Food Science, 74:8, C619-C627.

Benjakul, S., Visessanguan, W., Riebroy, S., Ishizaki, S., \& Tanaka, M. (2002). Gel-forming properties of surimi produced from big eye snapper, Priacanthus tayenus and P. macracanthus, stored in ice. Journal of the Science of Food Agriculture, 82:1442-51.

Berglund, D.R. (2002). Flax: new uses and demands. In Trends in New Crops and New Uses (J. Janick and A. Whipkey, eds.) pp. 358-360, ASHS Press, Alexandria, VA.

Bottiger, L. E., Dyerberg, J., \& Nordoy, A. (1989). n-3 fish oils in clinical medicine. Journal of Internal Medicine, 225(Suppl 1):1-238.

Cahu, C., Salen, P., \& de Lorgeril, M. (2004). Farmed and wild fish in the prevention of cardiovascular diseases: Assessing possible differences in lipid nutritional values. Nutrition, Metebolism and Cardiovascular Diseases, 14, 34-41.

Chapman, K. W., \& Regenstein, J. M. (1997). Use of fish oils in food products. In Seafood Safety, Processing and Biotechnology; Shahidi, F., Jones, Y., Kitts, D., Eds.; Technomic Publishing: New York, Chapter 16, pp 151-159.

Chen, Y. C., \& Jaczynski, J. (2007a). Gelation of protein recovered from Antarctic krill (Euphausia superba) by isoelectric solublization/precipitation as affected by function additives. Journal of Agricultural and Food Chemistry, 55, 1814-1822.

Chen, Y. C., \& Jaczynski, J. (2007b). Protein recovery from rainbow trout (Oncorhynchus mykiss) processing by-products via isoelectric solubilization/precipitation and its gelation properties as affected by functional additives. Journal of Agricultural and Food Chemistry, 55, 9079-9088.

Chen, Y. C., Tou, J. C., \& Jaczynski, J. (2007). Amino acid, fatty acid, and mineral profiles of materials recovered from rainbow trout (Oncorhynchus mykiss) processing by-products using isoelectric solubilization/precipitation. Journal of Food Science, 72(9), C527-C535.

Chen, Y. C., Tou, J. C., \& Jaczynski, J. (2009) Amino acid and mineral composition of protein and other components and their recovery yields from whole Antarctic krill (Euphausia superba) using isoelectric solubilization/precipitation. Journal of Food Science, 74(2), H31-H39. 
Chen, Y. C., Nguyen, J., Semmens, K., Beamer, S., \& Jaczynski, J. (2007). Physicochemical changes in omega-3-enhanced farmed rainbow trout (Oncorhynchus mykiss) muscle during refrigerated storage. Food Chemistry, 104(3), 1143-1152.

Chen, Y. C., Nguyen, J., Semmens, K., Beamer, S., \& Jaczynski, J. (2006). Enhancement of omenga-3 fatty acid content in rainbow trout (Oncorhynchus mykiss) fillets. Journal of Food Science, 71(7), C383-C389.

Chen, Y. C., Nguyen, J., Semmens, K., Beamer, S., \& Jaczynski, J. (2008a). Effects of dietary alpha-tocopheryl acetate on lipid oxidation and alpha-tocopherol content of novel omega-3enhanced farmed rainbow trout (Oncorhynchus mykiss) fillets. LWT-Food Science and Technology, 41(2), 244-253.

Choi, Y. J., \& Park, J.W. (2002). Acid-aided protein recovery from enzyme-rich Pacific whiting. Journal of Food Science, 67, 2962-2967.

Crawford, M. A. (1968). Fatty acid ratios in free-living and domestic animals. Lancet, I: 132933.

Eaton, S. B., \& Konner, M. (1985). Paleolithic nutrition. A consideration of its nature and current implications. New England Journal of Medicine, 312:283-9.

Eaton, S. B., Konner, M., \& Shostak, M. (1988). Stone agers in the fast lane: chronic degenerative diseases in evolutionary perspective. American Journal of Medicine, 84:739-49.

Foegeding, E. A., Xiong, Y. L., \& Brekke, C. J. (1991). Gelation of myofibrillar protein. In N. Paris, \& R. Barford (Eds.), Interactions of food proteins (pp. 257-267).

Food and Agriculture Organization of the United Nations. Fishery and aquaculture statistics. FAO statistical yearbook. Rome, Italy, 2008.

Freeman, M. P. (2000). Omega-3 fatty acids in psychiatry. A review. Annual Review of Clinical Psychology, 12, 159-165.

Freeman, M.P., Hibbeln, J.R., Wisner, K.L., Davis, J.M., Mischoulon, D., Peet, M., Keck, P.E., Marangell, L.B., Richardson, A.J., Lake, J., \& Stoll, A.L. (2006). Omega-3 fatty acids: evidence basis for treatment and future research in psychiatry. Journal of Clinical Psychiatry, 67, 19541967.

Freud, R. J., \& Wilson, W. J. (1997). Design of experiments. San Diego (CA): Academic Press, p. 464.

Gigliotti, J. C., Jaczynski, J., Tou, J. C. (2008). Determination of the nutritional value, protein quality and safety of krill protein concentrate isolated using an isoelectric solubilization /precipitation technique. Food Chemistry, 111(1), 209-214. 
Goulas, A. E., \& Kontominas, M. G. (2005). Effect of salting and smoking-method on the keeping quality of chub mackerel (Scomber japonicus): biochemical and sensory attributes. Food Chemistry, 93, 511-520.

Gram, L., \& Huss, H. H. (1996). Microbial spoilage of fish and fish products. International Journal of Food Microbiology, 33:121-37.

Hamman, D. D., \& Lanier, T. C. (1987). Instrumental methods for predicting seafood sensory texture quality. In D. E. Kramer, \& J. Liston (Eds.), Seafood quality determination (pp. 123136). Amsterdam, Netherlands: Elsevier Science Publishers BV.

Hedges, N. (2002). Maintaining the quality of frozen fish, in Safety and Quality Issues in Fish Processing, Bremner, A., Ed. Woodhead Publisher, Cambridge, England, p. 379.

Holm, T., Andreassen, A.K., Aukrust, P. et al. (2001). Omega-3 fatty acids improve blood pressure control and preserve renal function in hypertensive heart transplant recipients. European Heart Journal, 22, 428-436.

Hyldig, G. \& Nielsen, D. (2001). A review of sensory and instrumental methods to evaluate the texture of fish muscle, Journal of Textural Studies, 32, 165.

Jaczynski, J., \& Park, J. W. (2003). Physicochemical properties of surimi seafood as affected by electron beam and heat. Journal of Food Science, 68(5), 1626-1630.

Jaczynski, J. \& Park, J. W. (2004). Physicochemical changes in Alaska Pollock surimi and surimi gel as affected by electron beam. Journal of Food Science, 69, 53-57.

Kassis, N., Gigliotti, J.C., Beamer, S.K., Tou, J.C., \& Jaczynski, J. (2011). Characterization of lipids and antioxidant capacity of novel nutraceutical egg products developed with omega-3-rich oils. Journal of the Science of Food and Agriculture, under review.

Ke, P. J., Cervantes, E., \& Robles-Martinez, C. (1984). Determination of thiobarbituric acid reactive substances (TBARS) in fish tissue by an improved distillation spectrophotometric method. Journal of the Science of Food and Agriculture, 35, 1248-1254.

Kim, B. Y., Hamman, D. E., Lanier, T. C., \& Wu, M. C. (1986). Effects of freeze-thaw abuse on the viscosity and gel-forming properties of surimi from two species. Journal of Food Science, 51(4), 951-956.

Kim, Y. S., Park, J. W., \& Choi, Y. J. (2003). New approaches for the effective recovery of fish proteins and their physicochemical characteristics. Fisheries Science. 69(6), 1231-1239.

Kristinsson, H. G., \& Hultin, H. O. (2003). Changes in conformation and subunit assembly of cod myosin at low and high $\mathrm{pH}$ and after subsequent refolding. Journal of Agricultural and Food Chemistry, 51(24), 7187-7196. 
Lansdowne, L., Beamer, S., Jaczynski, J., \& Matak, K. E. (2009a).Survival of Escherichia coli after isoelectric solubilization/precipitation of fish. Journal of Food Protection. 72(7), 13981403.

Lansdowne, L., Beamer, S., Jaczynski, J., \& Matak, K. E. (2009b). Survival of Listeria innocua after isoelectric solubilization and precipitation of fish protein. Journal of Food Science, 74(4), M201-M205.

Ledger, H. P. (1968). Body composition as a basis for a comparative study of some East African animals. Symp Zool Soc London, 21: 289-310.

Lee, C.M. \& Abdollahi A. (1981). Effects of hardness of plastic fat on structure and material properties of fish protein gels. Journal of Food Science, 46, 1755-1759.

Marmon, S. K., Liljelind, P., \& Undeland, I. (2009). Removal of lipids, dioxins and polychlorinated biphenyls during production of protein isolates from Baltic herring (Clupea harengus) using pH-shift process. Journal of Agricultural and Food Chemistry, 57, 7819-7825.

Mireles, DeWitt, C. A., \& Gomez, G., (2002). James, J. M. Protein extraction from beef heart using acid solubilization. Journal of Food Science, 67, 3335-3341.

Mireles, DeWitt, C. A., Nabors, R. L., \& Kleinholz, C. W. (2007). Pilot plant scale production of protein from catfish treated by acid solubilization/isoelectric precipitation. Journal of Food Science, 72, E351-E355.

Mooney, B.D., Nichols, P.D., \& Elliott, N.G. (2002). Seafood the Good Food II. Oil profiles for further Australian seafoods, and influencing factors. FRDC Project 99/331. Guide prepared for the Fisheries Research and Development Corporation, Australia; CSIRO: Hobart, Australia.

Nair, S. S. D., Leitch, J. W., Falconder, J., \& Garg, M. L. (1997). Prevention of cardiac arrhythmia by dietary (n-3) polyunsaturated fatty acids and their mechanism of action. Journal of Nutrition, 127, 383-393.

National Research Council. (1993). Composition of feed ingredients. Washington, D.C.: National Academy Press, LLC.

Nichols, P.D., Virtue, P., Mooney, B.D., Elliott, N.G., \& Yearsley, G.K. (1998). Seafood the Good Food. The oil content and composition of Australian commercial fishes, shellfishes and crustaceans. FRDC Project 95/122. Guide prepared for the Fisheries Research and Development Corporation, Australia; CSIRO: Hobart, Australia.

Newton, I. S. (1998). Global food fortification perspectives of long-chain $\omega-3$ fatty acids. In The Return of $\omega-3$ Fatty Acids into the Food Supply, I. Land-Based Animal Food Products and Their Health Effects. World Review Nutrition and Dietetics; Simopoulos, A. P., Ed.; Karger: New York; Vol. 83, pp 199-209. 
Nolsoe, H., \& Undeland, I. (2009).The acid and alkaline solubilization process for the isolation of muscle proteins: state of the art. Food Bioprocess Technology, 2, 1-27.

Park, J.W. (2005). Ingredient technology for surimi and surimi seafood. In J.W. Park (Ed.), Surimi and surimi Seafood (2nd, ed.). (pp. 649-707) Boca Raton (FL): Taylor and Francis Group.

Pietrowski, B., Tahergorabi, R., Beamer, S., Matak, K., Tou, J., \& Jaczynski, J. (2011). Chemical properties of surimi seafood nutrified with $\omega-3$ rich oils, Food Chemistry, 129: 912-919.

Perez-Mateos, M., Boyd, L.C., \& Lanier, T.C. (2004). Stability of omega-3 fatty acids in fortified surimi seafoods during chilled storage. Journal of Agricultural and Food Chemistry, 55:7944-7949.

SAS Institute (2002). SAS/ STAT guide for personal computers, version 8.1. Cary (NC): SAS Institute.

Senso, L., Suarez, M. D, Ruiz-Cara, T. \& Gar-cia-Gallego, M. (2007). "On the Possible Effects of Harvesting Sea-son and Chilled Storage on the Fatty Acid Profile of the Fillet of Farmed Gilthead Sea Bream (Sparus aurata)," Food Chemistry, Vol. 101, No. 1, pp. 298-307.

Sikorski, Z., Kolakowska, A., \& Burt, J.R. (1990). Postharvest biochemical and microbial changes. In: Sikorski ZE, editor. Seafood: resources, nutritional composition and preservation. Boca Raton, Fla.: CRC Press. p 55-7.

Simopoulos, A.P. (1991).Omega-3 fatty acids in health and disease and in growth and development. Journal of American College Nutrition, 54:438-63.

Simopoulos, A.P. (1995). Trans fatty acids. In: Spiller GA, editor. Handbook of lipids in human nutrition. Boca Raton: CRC Press. p. 91-9.

Simopoulos, A.P. (1999a). Genetic variation and evolutionary aspects of diet. In: PapasA, editor. Antioxidants in nutrition and health. Boca Raton: CRC Press. p. 65-88.

Simopoulos, A.P. (1999b). Evolutionary aspects of omega-3 fatty acids in the food supply. Prostaglandins, Leukotrienes and essential fatty acids, 60(5/6):421-9.

Simopoulos, A.P.( 1999c). New products from the agri-food industry: the return of n-3 fatty acids into the food supply. Lipids; 34(Suppl):S297-301.

Singh, R., Chatli, M, K., Biswas, A. K., \& Sahoo, J. (2011). Quality and storage stability of chicken meat patties incorporated with linseed oil. Journal of Food Quality, 1-11.

Tahergorabi, R., Beamer, S., Matak, K.E., \&Jaczynski, J. (2011a). Effect of isoelectric solubilisation / precipitation and titanium dioxide on whitening and texture of proteins recovered from dark chicken-meat processing by-products. LWT-Food Science and Technology, 44(4):896-903. 
Tahergorabi R, Sivanandan L, Jaczynski J. 2012. Dynamic rheology and endothermic transitions of proteins recovered from chicken-meat processing by-products using isoelectric solubilization / precipitation and addition of $\mathrm{TiO}_{2}$. LWT - Food Science and Technology, 46(1):148-55.

Tahergorabi R, Beamer S K, Matak K E, Jaczynski J. 2012. Salt substitution in surimi seafood and its effects on instrumental quality attributes. LWT - Food Science and Technology. DOI: 10.1016/j.lwt.2012.03.004

Tarladgis, B.G. et al. (1960). A distillation method for the quantitative determination of malonaldehyde in rancid foods, Journal of American Oil Chemist Society, 37, 44.

Taskaya, L.; Chen, Y. C., Beamer, S., \& Jaczynski, J. (2009a). Texture and color properties of proteins recovered from whole gutted silver carp (Hypophthalmichthys molitrix) using isoelectric solubilisation/precipitation. Journal of the Science of Food and Agriculture, 89(2), 349-358.

Taskaya, L., Chen, Y. C., \& Jaczynski, J. (2009b). Functional properties of proteins recovered from whole gutted silver carp (Hypophthalmichthys molitrix) by isoelectric solubilization/precipitation. LWT - Food Science and Technology, 42(6), 1082-1089.

Taskaya, L., Chen, Y. C., Beamer, S., Tou, J. C. \& Jaczynski, J. (2009c). Compositional characteristics of materials recovered from whole gutted silver carp (Hypophthalmichthys molitrix) using isoelectric solubilization/precipitation. Journal of Agricultural and Food Chemistry, 57(10), 4259-4266.

Taskaya, L., Chen, Y. C., \& Jaczynski, J. (2010). Color improvement by titanium dioxide and its effect on gelation and texture of proteins recovered from whole fish using isoelectric solubilization /precipitation. LWT - Food Science and Technology, 43(3), 401-408.

Turchini, G.M., Mentasti, T., Frøyland, L., Orban, E., Caprino, F., Moretti, V.M. and Valfre`, F., 2003. Effect of alternative dietary lipid sources on performances, tissue chemical composition, mitochondrial fatty acid oxidation capabilities and sensory characteristics in brwn trout (Salmo trutta 1). Aquaculture, 225, 251-267.

Ulbritch, T. L. V. \& Southgate, D. A. T. (1991). "Coronary Heart Disease: Seven Dietary Factors," Lancet, Vol. 338, pp. 985-992.

Undeland, I., Kelleher, S. D., \& Hultin, H. O. (2002). Recovery of functional proteins from herring light muscle by an acid or alkaline solubilization process. Journal of Agricultural and Food Chemistry, 50, 7371-7379.

Undeland, I. Storrù, T. Rustad, N. Hedges, \& I. Medina. (2008). Preventing lipid oxidation in seafood, C. Jacobsen, I. In: improving seafood products for the consumer. Edited by Bùrresen, T, 426- 453. 
Valfre', Caprino \& Turchini. (2003).The Health Benefit of Seafood. Veterinary Research Communications, 27 Suppl. 1, 507-512.

Ward, Q. W. \& Singh, A. (2005). Omega-3/6 fatty acids: alternative sources of production. Process Biochemistry, 40, 3631.

Wu, M., Xiong, Y. L., Chen, J., Tang, X., \& Zhou, G. (2009). Rheological and microstructural properties of porcine myofibrillar protein-lipid emulsion composite gel. Journal of Food Science, $74,207-217$

Xiong, Y. L. (1992). Thermally induced interactions and gelation of combined myofibrillar protein from white and red broiler muscles. Journal of Food Science, 57, 581-585.

Ziegler, G.R. \& Foegeding, E. A. (1990). The gelation of proteins, in Advances in food and nutrition research, ed. by Kinsella JE. Academic Press, New York, pp. 203-298. 


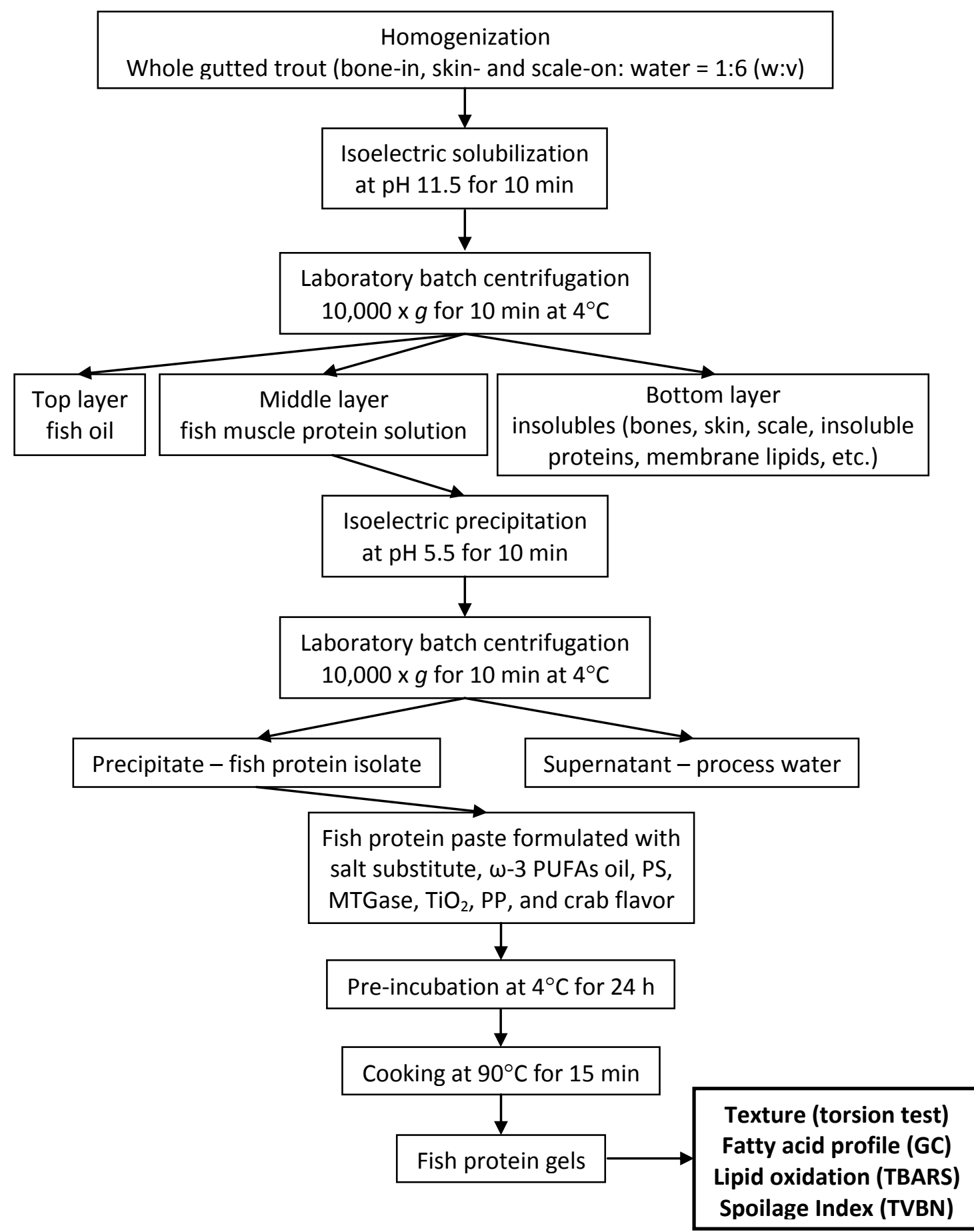

Figure 1. A flowchart for recovery of fish protein isolate using isoelectric solubilization /precipitation (ISP) and subsequent development of fish protein gels. The gels were formulated to contain 78\% moisture, $0.34 \mathrm{M}$ salt substitute, 10\% $\omega-3$ PUFAs oil (flaxseed, fish, algae, krill, or blend), $2 \%$ potato starch (PS), $0.5 \%$ microbial transglutaminase (MTGase), $0.5 \%$ titanium dioxide $\left(\mathrm{TiO}_{2}\right) 0.3 \%$ polyphosphate (PP), and $3.7 \%$ crab flavor. The paste $\mathrm{pH}$ was adjusted to 7.2 . 

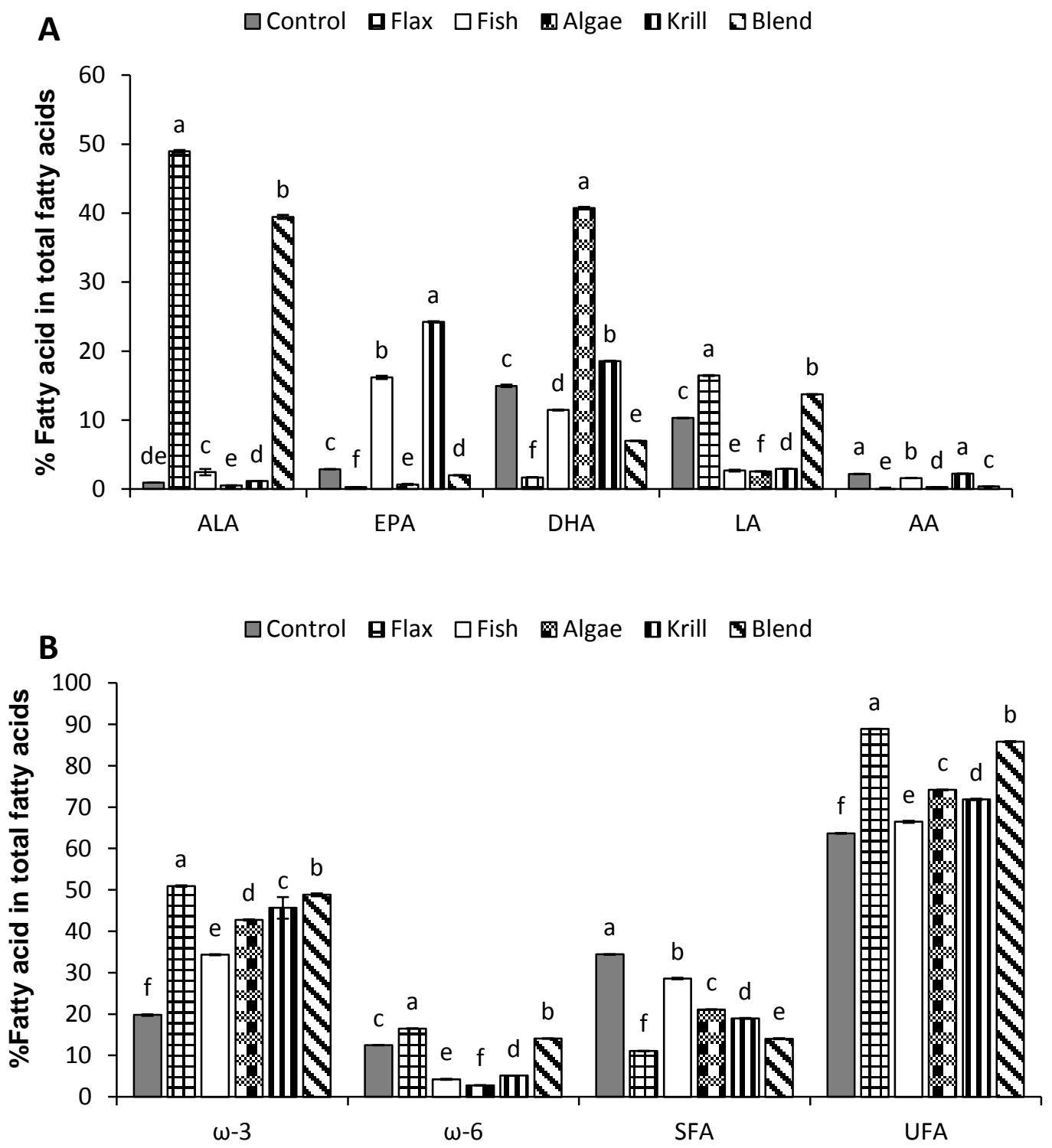

Figure 2. Major fatty acids* (FAs) of heat-set trout gels with and without (control) added oil (blend was flaxseed: algae: fish, 8:1:1). *Data are given as mean values \pm standard deviation $(\mathrm{n}=$ 3). Different letters on data bars indicate significant differences (Fisher's Least Significant Difference, $\mathrm{P}<0.05$ ) between mean values within the same FA. ** (A) ALA-linolenic (18:3 103$)$,

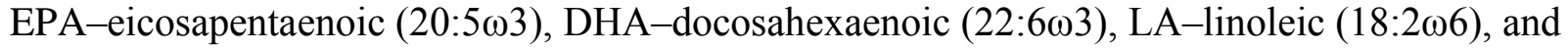

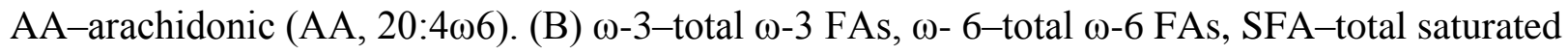
FAs, and UFA-total unsaturated FAs. 
Table 1

The ratios ${ }^{a}$ of omega-6/omega-3 fatty acids ( $\left.\omega-6 / \omega-3\right)$ and unsaturated/saturated fatty acids (UFAs/SFAs) and IA= Index of atherogenicity; IT = Index of thrombogenicity determined for heat-set trout gels with and without (control) added oil (blend was flaxseed: algae: fish, 8:1:1).

\begin{tabular}{ccccccc}
\hline & Control & Flax & Fish & Algae & Krill & Blend \\
\hline$\omega-6 / \omega-3$ & $0.63 \pm 0.00$ & $0.32 \pm 0.00$ & $0.12 \pm 0.00$ & $0.07 \pm 0.00$ & $0.11 \pm 0.01$ & $0.29 \pm 0.00$ \\
& $\mathrm{a}$ & $\mathrm{b}$ & $\mathrm{d}$ & $\mathrm{f}$ & $\mathrm{e}$ & $\mathrm{c}$ \\
UFAs/SFAs & $1.85 \pm 0.00$ & $8.01 \pm 0.05$ & $2.32 \pm 0.02$ & $3.51 \pm 0.01$ & $3.79 \pm 0.01$ & $6.1 \pm 0.06$ \\
& $\mathrm{f}$ & $\mathrm{a}$ & $\mathrm{e}$ & $\mathrm{d}$ & $\mathrm{c}$ & $\mathrm{b}$ \\
IA & $0.62 \pm 0.00$ & $0.11 \pm 0.00$ & $0.73 \pm 0.03$ & $0.69 \pm 0.01$ & $0.34 \pm 0.00$ & $0.22 \pm 0.02$ \\
& $\mathrm{c}$ & $\mathrm{f}$ & $\mathrm{a}$ & $\mathrm{b}$ & $\mathrm{d}$ & $\mathrm{e}$ \\
IT & $0.41 \pm 0.00$ & $0.05 \pm 0.00$ & $0.21 \pm 0.02$ & $0.12 \pm 0.00$ & $0.11 \pm 0.00$ & $0.08 \pm 0.00$ \\
& $\mathrm{a}$ & $\mathrm{e}$ & $\mathrm{b}$ & $\mathrm{c}$ & $\mathrm{c}$ & $\mathrm{d}$ \\
\hline
\end{tabular}

Data are given as mean values \pm standard deviation $(n=3)$. Different letters indicate significant differences (Fisher's Least Significant Difference, $\mathrm{P}<0.05)$ between mean values within the same row. 


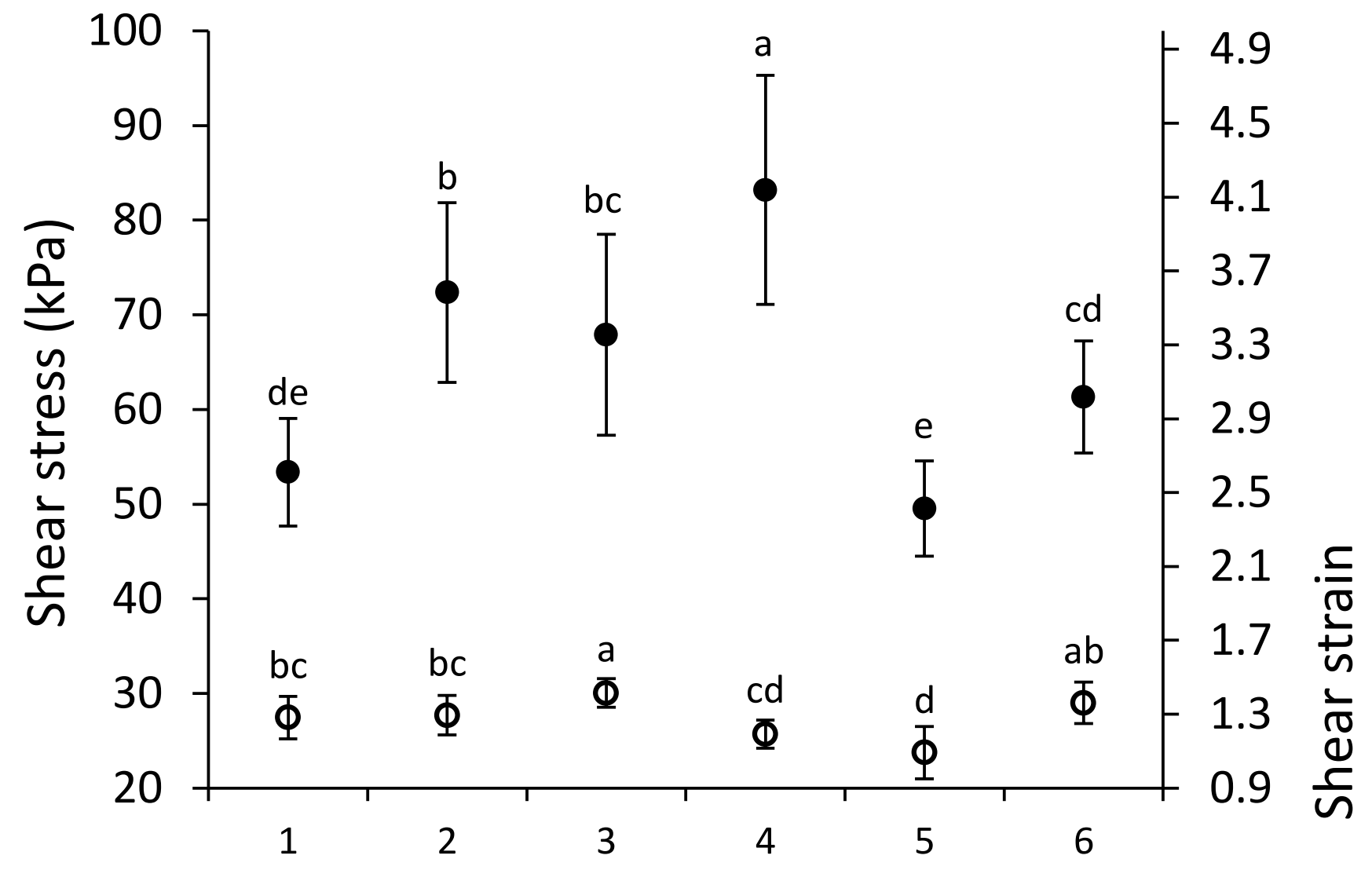

Figure 3. Torsion shear stress* and strain* of heat-set fish protein gels with and without (control) added $\omega$-3-rich oils $(\bullet-$ shear stress; $\circ$ - shear strain).

* Data are given as mean values \pm standard deviation $(\mathrm{SD})(\mathrm{n}=3)$. Bars on data points indicate SD. Different letters on the top of SD bars indicate significant differences (Fisher's Least Significant Difference test, $\mathrm{P}<0.05, \mathrm{n}=3$ ). 


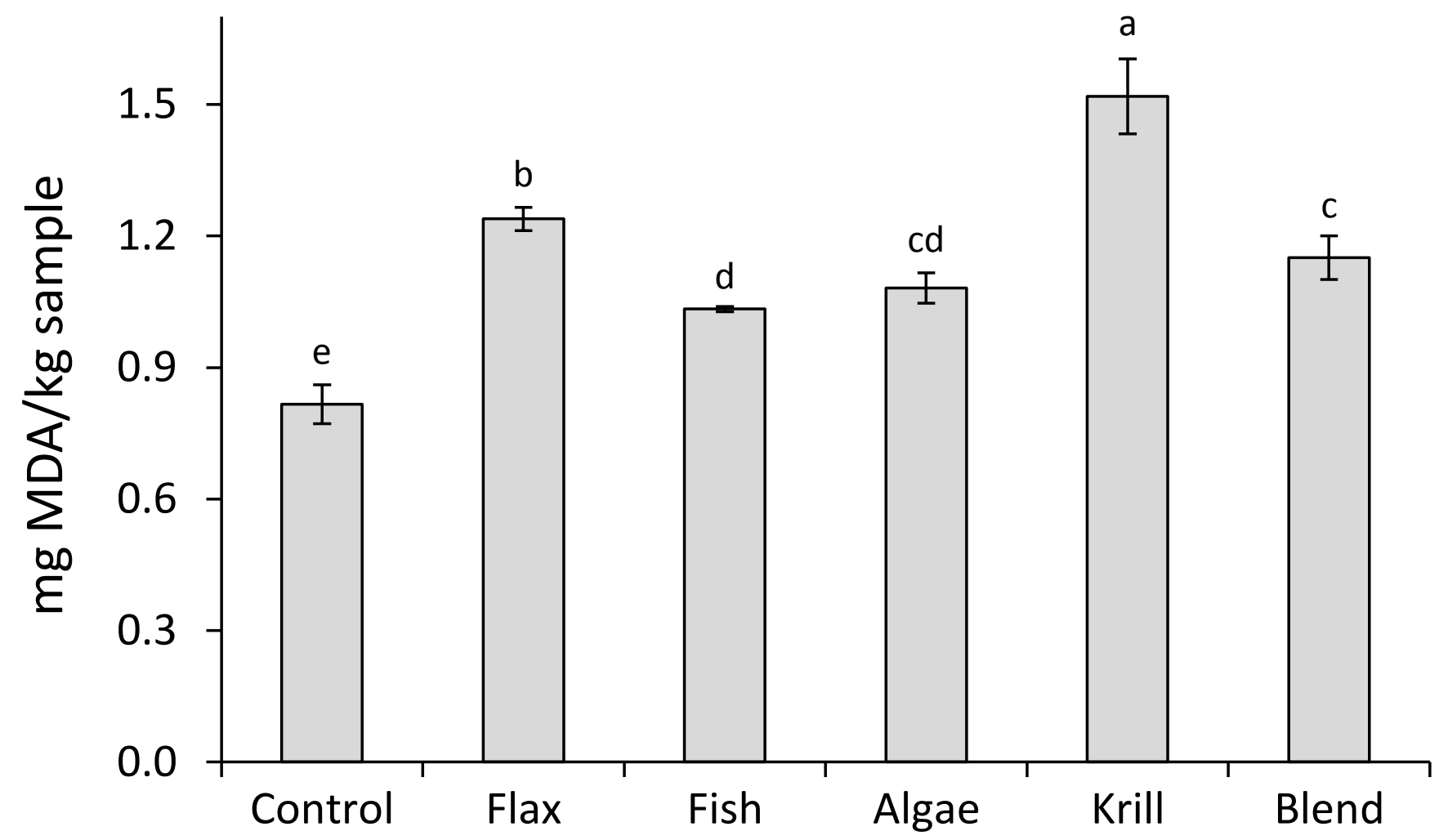

Figure 4. Thiobarbituric reactive substances (TBARS) values* of heat-set fish protein gels with and without (control) added $\omega$-3-rich oils.

* Data are given as mean values \pm standard deviation $(\mathrm{SD})(\mathrm{n}=3)$. The small bars of the top of data bars indicate SD. Different letters on the top of SD bars indicate significant differences between mean values (Fisher's Least Significant Difference test, $\mathrm{P}<0.05, \mathrm{n}=3$ ). 


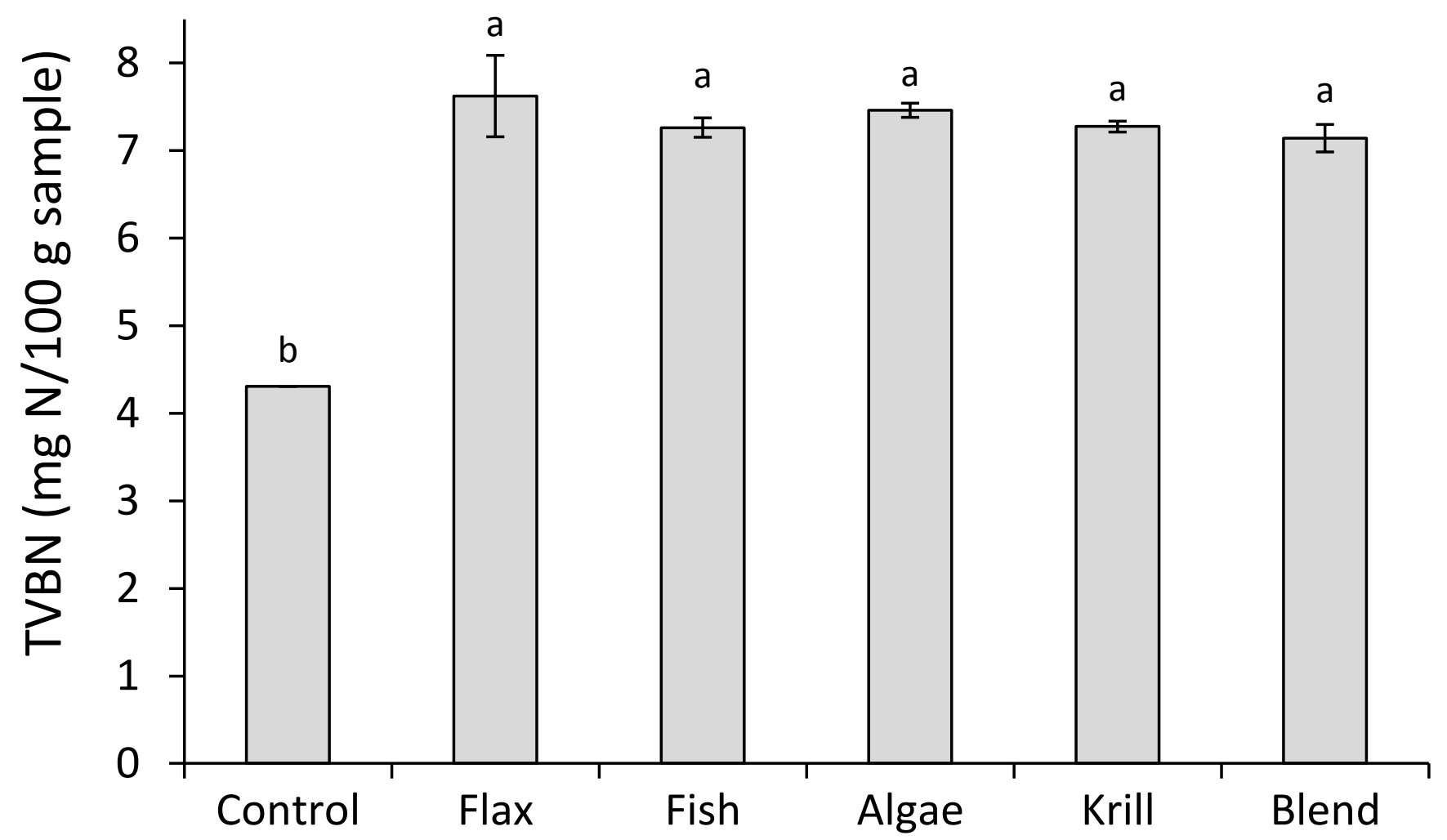

Figure 5. Total volatile basic nitrogen (TVBN) values* of heat-set fish protein gels with and without (control) added $\omega$-3-rich oils.

* Data are given as mean values \pm standard deviation $(\mathrm{SD})(\mathrm{n}=3)$. The small bars of the top of data bars indicate SD. Different letters on the top of SD bars indicate significant differences between mean values (Fisher's Least Significant Difference test, $\mathrm{P}<0.05, \mathrm{n}=3$ ). 


\section{Dissertation Summary and Implications}

Muscle protein extraction from "low value" poultry meat and fish by-products has been receiving increased attention. Color is one of the concerns with these products, and it affects consumers' selection and satisfaction. One of the attempts to increase the utilization of these processing by-products is using isoelectric solubilization/precipitation (ISP) to recover myofibrillar proteins and separate them from pigments and fat to increase their utilization for the preparation of further processed meat products. On the other hand, the present Western diet is characterized as high salt content and low $\omega-3$ fatty acids which provides the risk factors for cardiovascular diseases.

Based on the results reported in this dissertation, ISP allows recovery of proteins from skin-on bone-in dark chicken-meat processing by-products without removal of bones, skin, and fat prior to processing. Addition of $\mathrm{TiO}_{2}$ to proteins recovered from these by-products allows development of heat-set gels with color and texture comparable to chicken breast gels.

Addition of salt substitute significantly reduced $(\mathrm{P}<0.05)$ sodium content in surimi gels. Salt substitute and salt result in similar physicochemical properties of surimi gels, but gels developed with salt substitute have much lower sodium content. Therefore, salt substitute can be used to replace $\mathrm{NaCl}$ in low-sodium surimi seafood products.

Addition of $\omega-3$ PUFAs rich oils (flaxseed, algae, fish, krill and blend) enhanced nutritional properties of trout protein isolates. The trout gels had a higher content of $\omega-3$ PUFAs, in particular ALA, EPA and DHA while the texture properties were improved and lipid oxidation was in acceptable range. Incorporation of PUFA rich oils into rainbow trout protein isolate could produce a functional food product which mimics natural fish products. 